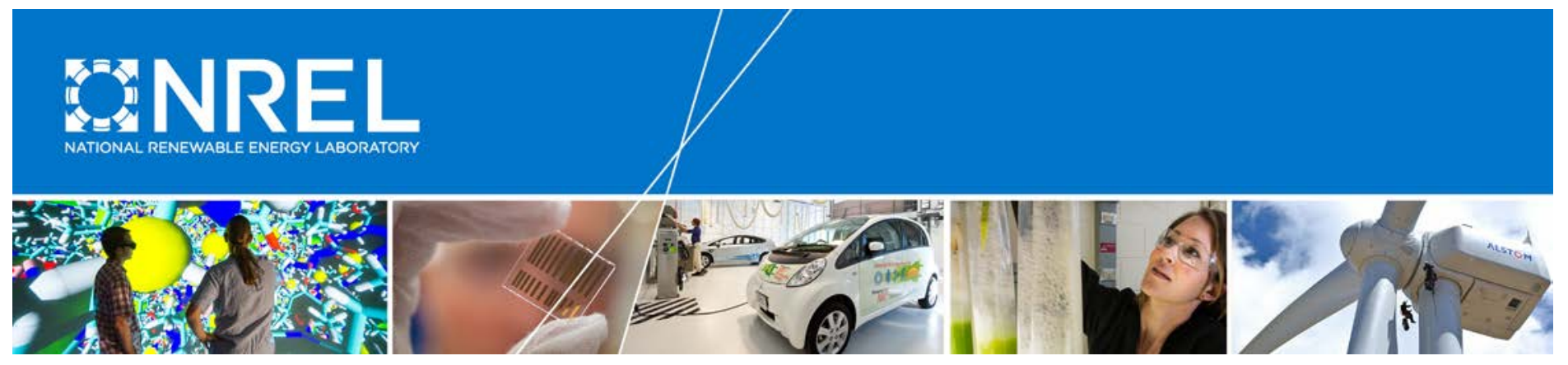

\title{
2014 Cost of Wind Energy Review
}

Christopher Moné, Tyler Stehly, Ben Maples, and Edward Settle

National Renewable Energy Laboratory

NREL is a national laboratory of the U.S. Department of Energy Office of Energy Efficiency \& Renewable Energy Operated by the Alliance for Sustainable Energy, LLC

This report is available at no cost from the National Renewable Energy Laboratory (NREL) at www.nrel.gov/publications.

\section{Technical Report}

NREL/TP-6A20-64281

October 2015 


\section{Cost of Wind Energy Review}

Christopher Moné, Tyler Stehly, Ben Maples, and Edward Settle

National Renewable Energy Laboratory

Prepared under Task No. WE15.CA03

NREL is a national laboratory of the U.S. Department of Energy

Office of Energy Efficiency \& Renewable Energy

Operated by the Alliance for Sustainable Energy, LLC

This report is available at no cost from the National Renewable Energy Laboratory (NREL) at www.nrel.gov/publications.

National Renewable Energy Laboratory 15013 Denver West Parkway

Golden, CO 80401

303-275-3000 • www.nrel.gov

\section{Technical Report}

NREL/TP-6A20-64281

October 2015

Contract No. DE-AC36-08GO28308 


\title{
NOTICE
}

This report was prepared as an account of work sponsored by an agency of the United States government. Neither the United States government nor any agency thereof, nor any of their employees, makes any warranty, express or implied, or assumes any legal liability or responsibility for the accuracy, completeness, or usefulness of any information, apparatus, product, or process disclosed, or represents that its use would not infringe privately owned rights. Reference herein to any specific commercial product, process, or service by trade name, trademark, manufacturer, or otherwise does not necessarily constitute or imply its endorsement, recommendation, or favoring by the United States government or any agency thereof. The views and opinions of authors expressed herein do not necessarily state or reflect those of the United States government or any agency thereof.

This report is available at no cost from the National Renewable Energy Laboratory (NREL) at www.nrel.gov/publications.

Available electronically at SciTech Connect http:/www.osti.gov/scitech

Available for a processing fee to U.S. Department of Energy and its contractors, in paper, from:

\author{
U.S. Department of Energy \\ Office of Scientific and Technical Information \\ P.O. Box 62 \\ Oak Ridge, TN 37831-0062 \\ OSTI http://www.osti.gov \\ Phone: 865.576.8401 \\ Fax: 865.576.5728 \\ Email: reports@osti.gov
}

Available for sale to the public, in paper, from:

\author{
U.S. Department of Commerce \\ National Technical Information Service \\ 5301 Shawnee Road \\ Alexandria, VA 22312 \\ NTIS http://www.ntis.gov \\ Phone: 800.553 .6847 or 703.605 .6000 \\ Fax: 703.605.6900 \\ Email: orders@ntis.gov
}




\section{Acknowledgments}

This work was supported by the U.S. Department of Energy (DOE) under Contract No. DEAC36-08GO28308 with the National Renewable Energy Laboratory (NREL). Funding for the work was provided by the DOE Office of Energy Efficiency and Renewable Energy, Wind and Water Power Technologies Office. The authors would like to extend thanks to José Zayas and Mark Higgins from the DOE Wind and Water Power Technologies Office for supporting this research. Thanks also to Rich Tusing and Dan Beals (DOE contractors) of the DOE Wind and Water Power Technologies Office, as well as Ryan Wiser (Lawrence Berkeley National Laboratory), Karlynn Cory, Eric Lantz, David Mooney, and David Corbus of NREL for reviewing and providing strategic guidance in the development of this work. Thanks to Aaron Barr (MAKE Consulting), Carsten Westergaard (Texas Tech University), and Susan Innis (Xcel Energy) for reviewing earlier versions of this report. Any remaining errors or omissions are the sole responsibility of the authors. 


\section{List of Acronyms}

\begin{tabular}{|c|c|}
\hline $\mathrm{AEP}_{\text {net }}$ & net annual energy production \\
\hline AEP & annual energy production \\
\hline ATB & Annual Technology Baseline \\
\hline AWEA & American Wind Energy Association \\
\hline BNEF & Bloomberg New Energy Finance \\
\hline BOEM & Bureau of Ocean Energy Management \\
\hline BOS & balance of system \\
\hline bp & basis point \\
\hline CapEx & capital expenditures \\
\hline $\mathrm{COE}$ & cost of energy \\
\hline $\mathrm{C}_{\mathrm{p}}$ & coefficient of power \\
\hline CPI & Consumer Price Index \\
\hline CRF & capital recovery factor \\
\hline DOE & U.S. Department of Energy \\
\hline EIA & U.S. Energy Information Administration \\
\hline EPC & engineering, procurement, and construction \\
\hline EWEA & European Wind Energy Association \\
\hline FCR & fixed charge rate \\
\hline IEA & International Energy Agency \\
\hline ITC & investment tax credit \\
\hline LBNL & Lawrence Berkeley National Laboratory \\
\hline $\mathrm{kW}$ & kilowatt \\
\hline LCOE & levelized cost of energy \\
\hline LIBOR & London Interbank Offered Rate \\
\hline LLC & land lease cost \\
\hline $\mathrm{m}$ & meter \\
\hline $\mathrm{m} / \mathrm{s}$ & meter per second \\
\hline MACRS & Modified Accelerated Cost Recovery System \\
\hline MAIN & maintenance \\
\hline MW & megawatt \\
\hline MWh & megawatt-hour \\
\hline NREL & National Renewable Energy Laboratory \\
\hline O\&M & operation and maintenance \\
\hline OEM & original equipment manufacturer \\
\hline OPER & operation \\
\hline OpEx & operational expenditures \\
\hline OWDB & Offshore Wind Database \\
\hline PPA & power purchase agreement \\
\hline PTC & production tax credit \\
\hline PVdep & present value of depreciation \\
\hline SCBS & system cost breakdown structure \\
\hline WACC & weighted average cost of capital \\
\hline
\end{tabular}




\section{Executive Summary}

This report uses representative commercial projects to estimate the levelized cost of energy (LCOE) for both land-based and offshore wind plants in the United States for 2014. Scheduled to be published on an annual basis, the analysis relies on both market and modeled data to maintain an up-to-date understanding of wind generation cost trends and drivers. It is intended to provide insight into current component-level costs and a basis for understanding variability in the LCOE across the industry. Data and tools developed by the National Renewable Energy Laboratory (NREL) are used in this analysis to inform wind technology cost projections, goals, and improvement opportunities.

The primary elements of the 2014 report include:

- Estimated LCOE for a reference land-based wind project installed in a moderate wind resource typical of one located within the interior region of the United States in 2014

- Estimated range of LCOE for land-based wind projects across the contiguous United States based on geographically specific wind resource conditions paired with appropriate wind turbine size characteristics

- Estimated LCOE for a reference fixed-bottom U.S. offshore wind project reflecting projects currently in late-stage development on the North Atlantic Coast

- Sensitivity analyses showing the range of effects that basic LCOE variables could have on the cost of wind energy for land-based and offshore wind power plants

- Data that represent NREL's calculated historical LCOE for land-based and offshore wind plants.

The LCOE equation applied here is a standard methodology (Short et al. 1995, Electric Power Research Institute 2007, Blair et al. 2015) that includes four basic inputs: capital expenditures, operational expenditures, annual energy production (AEP), and the fixed charge rate (FCR; a coefficient that captures the average annual carrying charges including return on installed capital, depreciation, and taxes). Additional detail on the LCOE methodology can be found in the 2010 Cost of Wind Energy Review (Tegen et al. 2012). The LCOE values reported within the various reviews are expected to be greater than negotiated contract prices for wind power, as reflected by recent power purchase agreements (PPAs). This difference is because recent PPAs incorporate the value of the production tax credit (PTC), differences in depreciation methods, other renewable energy credits, or other applicable revenue streams.

\section{Key Inputs and Results}

Throughout this report, the representative land-based and offshore project types are referred to as "reference projects." Tables ES1 and ES2 summarize the four basic LCOE inputs for the reference land-based and fixed-bottom offshore wind projects, with some additional detail about project capital expenditures (CapEx) and the respective turbine capacity factor associated with the net AEP estimate. These are the assumptions used to calculate the LCOE for the 2014 reference projects using an installed average nameplate (megawatt [MW]) capacity. In each table, the left-hand column shows the data source. "Model" refers to the techno-economic models used, such as NREL's wind turbine design Cost and Scaling Model (Fingersh et al. 2006, Maples et al. 2010). "Market" indicates that NREL used current market data. For both, individual data sources, models, and methodologies are listed in the relevant sections of this report related to the specific cost components. 
Table ES1. Summary of the Land-Based Reference Project Using 1.94-MW Turbines

\begin{tabular}{|c|c|c|c|}
\hline \multicolumn{2}{|l|}{$\begin{array}{c}\text { Data } \\
\text { Source }^{a}\end{array}$} & $\begin{array}{l}\text { 1.94-MW Land- } \\
\text { Based Turbine } \\
\text { (\$/kilowatt [kW]) }\end{array}$ & $\begin{array}{l}\text { 1.94-MW Land- } \\
\text { Based Turbine } \\
\text { (\$/MWh) }\end{array}$ \\
\hline Model & Turbine capital cost & 1,221 & 35 \\
\hline Model & Balance of system & 345 & 10 \\
\hline Model & Financial costs & 154 & 3 \\
\hline Market & Market price adjustment ${ }^{\mathrm{b}}$ & -10 & 0 \\
\hline Market & Capital expenditures (CapEx) & 1,710 & 49 \\
\hline Market & Operational expenditures (OpEx; \$/kW/yr) & 51 & 15 \\
\hline Market & Fixed charge rate $(\%)$ & \multicolumn{2}{|c|}{10.3} \\
\hline Model & Net annual energy production (MWh/MW/yr) & \multicolumn{2}{|c|}{3,466} \\
\hline Model & Net capacity factor (\%) & \multicolumn{2}{|c|}{39.6} \\
\hline Calculated & TOTAL LCOE (\$/MWh) & \multicolumn{2}{|c|}{65} \\
\hline
\end{tabular}

Table ES2. Summary of the Fixed-Bottom Offshore Reference Project Using 3.39-MW Turbines

\begin{tabular}{|c|c|c|c|}
\hline $\begin{array}{c}\text { Data } \\
\text { Source }^{a}\end{array}$ & & $\begin{array}{l}\text { 3.39-MW } \\
\text { Offshore } \\
\text { Turbine }\end{array}$ & $\begin{array}{l}\text { 3.39-MW } \\
\text { Offshore } \\
\text { Turbine }\end{array}$ \\
\hline Model & Turbine capital cost & 1,952 & 51 \\
\hline Model & Balance of system & 2,277 & 60 \\
\hline Model & Financial costs & 1,084 & 29 \\
\hline Market & Market price adjustment & 612 & 16 \\
\hline Market & Capital expenditures (CapEx) & 5,925 & 156 \\
\hline Market & Operational expenditures (OpEx; \$/kW/yr) & 138 & 39 \\
\hline Market & Fixed charge rate $(\%)$ & & \\
\hline Model & Net annual energy production (MWh/MW/yr) & & \\
\hline Model & Net capacity factor (\%) & & \\
\hline Calculated & TOTAL LCOE (\$/MWh) & & \\
\hline
\end{tabular}

${ }^{a}$ Sources are listed in the relevant sections of this report related to the specific cost components.

${ }^{\mathrm{b}}$ The market price adjustment is the difference between the modeled cost and the average market price paid for the typical project in 2014.

Land-based wind project cost estimates were derived primarily from installed project data reported by Wiser and Bolinger (2015) and the American Wind Energy Association project 
database. These data were supplemented with outputs from NREL's wind turbine design Cost and Scaling Model (Fingersh et al. 2006, Maples et al. 2010). The land-based reference project was assumed to have a moderate wind resource regime, typical of what would be found within the interior region of the United States. Because of the absence of installed or operating offshore wind projects in the United States, the offshore reference project data were estimated from proposed U.S. projects and market data from the existing international offshore wind industry. The assumed wind resource regime for the offshore reference plant is comparable to that of the U.S. North Atlantic Coast.

As domestic and global wind markets mature, information about component-level costs are increasingly available. To manage and organize this component-level cost data, NREL has developed a system cost breakdown structure to break an entire wind project into smaller, more specific components (e.g., gearbox and generator). It provides a standardized approach to characterizing total lifetime expenditures for wind projects at the component level, including both physical (e.g., materials, labor, and equipment) and financial (e.g., insurance, construction financing, profit, and carrying charges) costs. More detailed breakdowns of CapEx are shown in Figures ES1 and ES2.

The three major component cost categories and many subcategories are represented in these figures, including wind turbine (e.g., wind turbine components), balance of system (e.g., development, electrical infrastructure, assembly, and installation), and financial costs (e.g., insurance and construction financing). From these data, it is clear that the breakdown of wind turbine component and installation costs varies greatly between land-based and offshore turbines. For example, the majority of the land-based project cost (71\%) is in the turbine itself, whereas the turbine makes up only $33 \%$ of the offshore reference project cost.

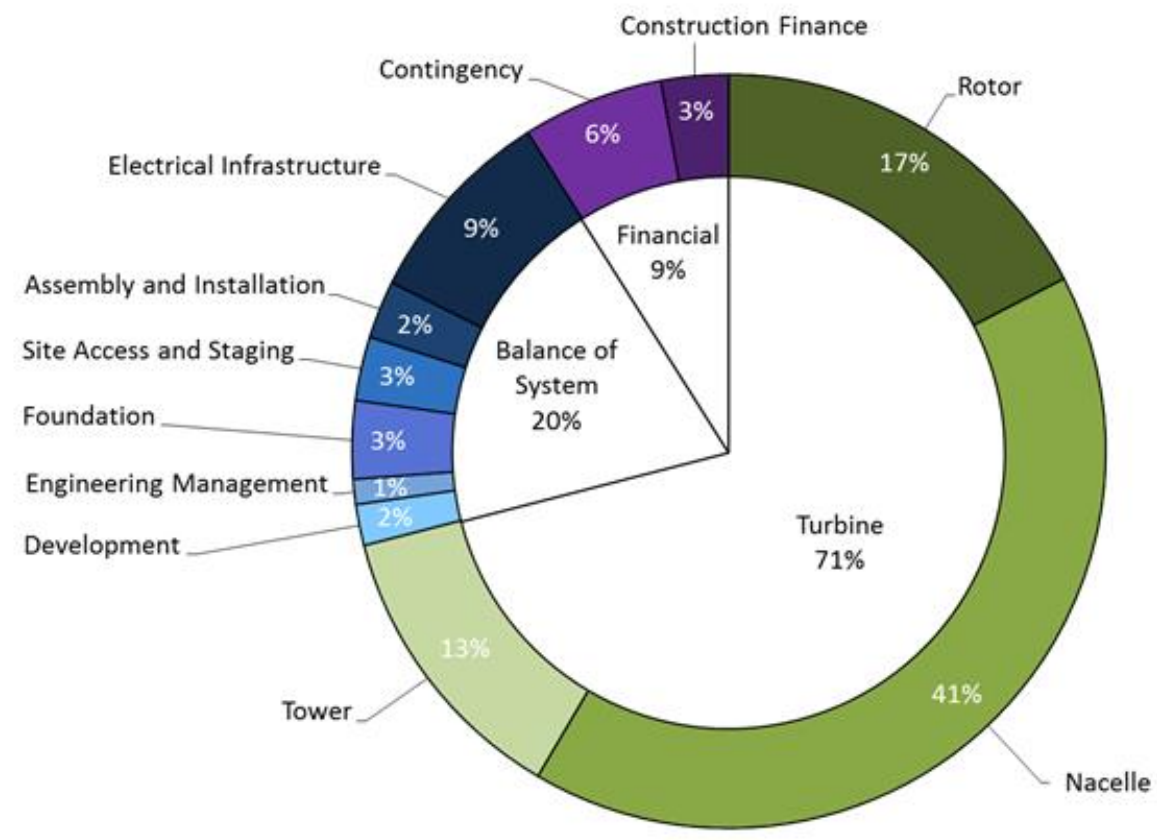

Figure ES1. Capital expenditures for the land-based reference wind plant project Source: NREL 


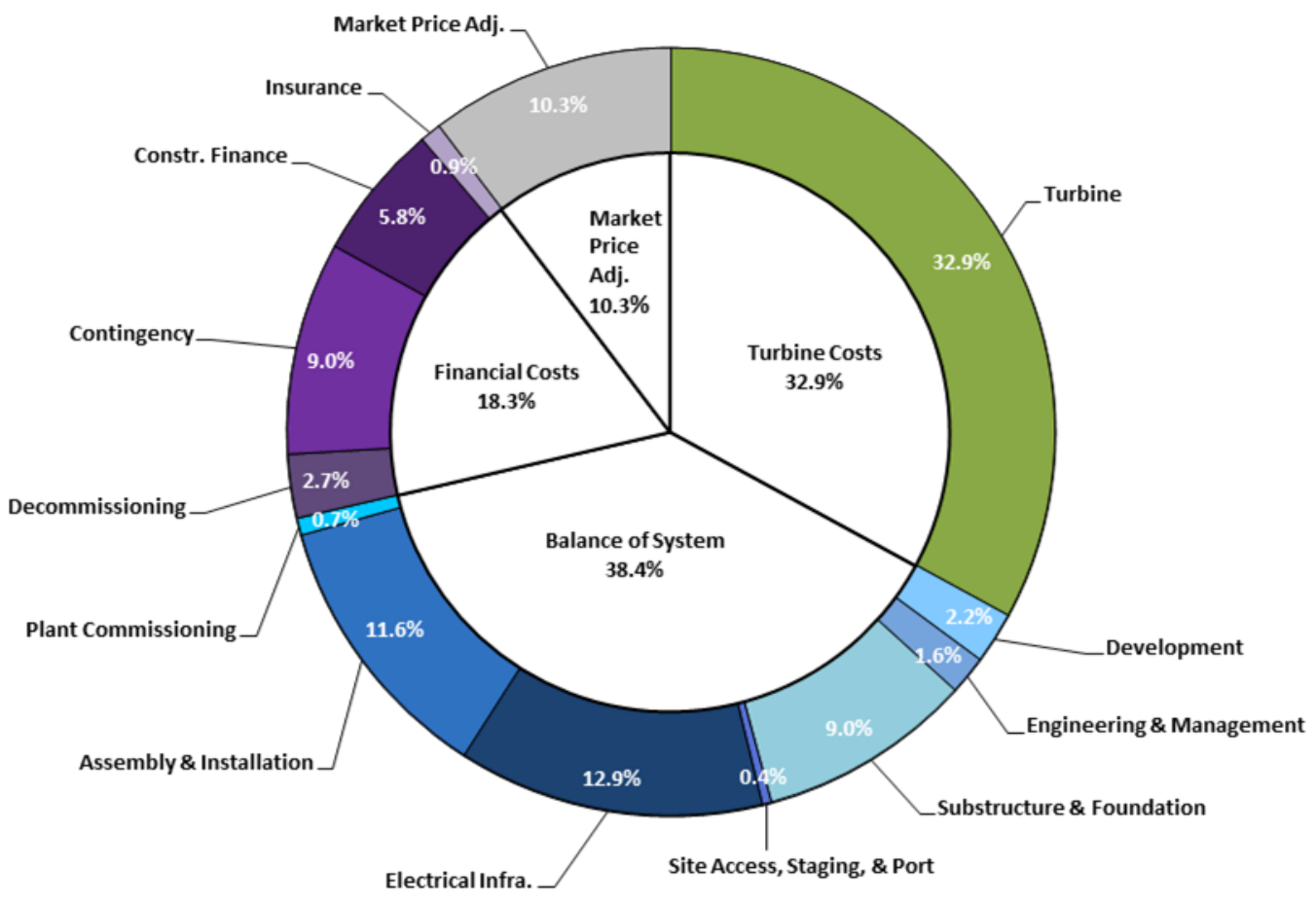

Figure ES2. Capital expenditures for the offshore reference wind plant project

Source: NREL

Figures ES3 and ES4 define the LCOE associated with the land-based and offshore reference plants and provide a range of sensitivities showing how specific variables affect cost and performance. Reference project values of $\$ 65 /$ megawatt-hour (MWh) for land-based wind and \$193/MWh for offshore wind rely on inputs summarized in Tables ES1 and ES2 (and are identified by the vertical white line in these figures). Figures ES3 and ES4 also show the observed industry ranges for LCOE inputs and the resulting LCOE. To provide more detail on the FCR, the authors divided it into two principal components: discount rate and economic operational life. AEP was converted to capacity factor to help convey the full range of performance reflected by 2014 projects. As shown, the land-based net capacity factors from 2014 projects range from $17.8 \%$ to $50.7 \%$ (Wiser and Bolinger 2015), with a calculated net capacity factor of $39.6 \%$ for the 2014 reference project. Clearly, the ranges for land-based and offshore wind LCOE inputs vary significantly (note the different axes in these figures). For example, offshore wind net capacity factor ranges from $30 \%$ to $55 \%$, with a calculated capacity factor of $42 \%$ for the reference project. Both figures show the effect capacity factor and CapEx have on the LCOE for both land-based and offshore wind projects. More detailed descriptions of the ranges and assumptions are included in the body of the report. 


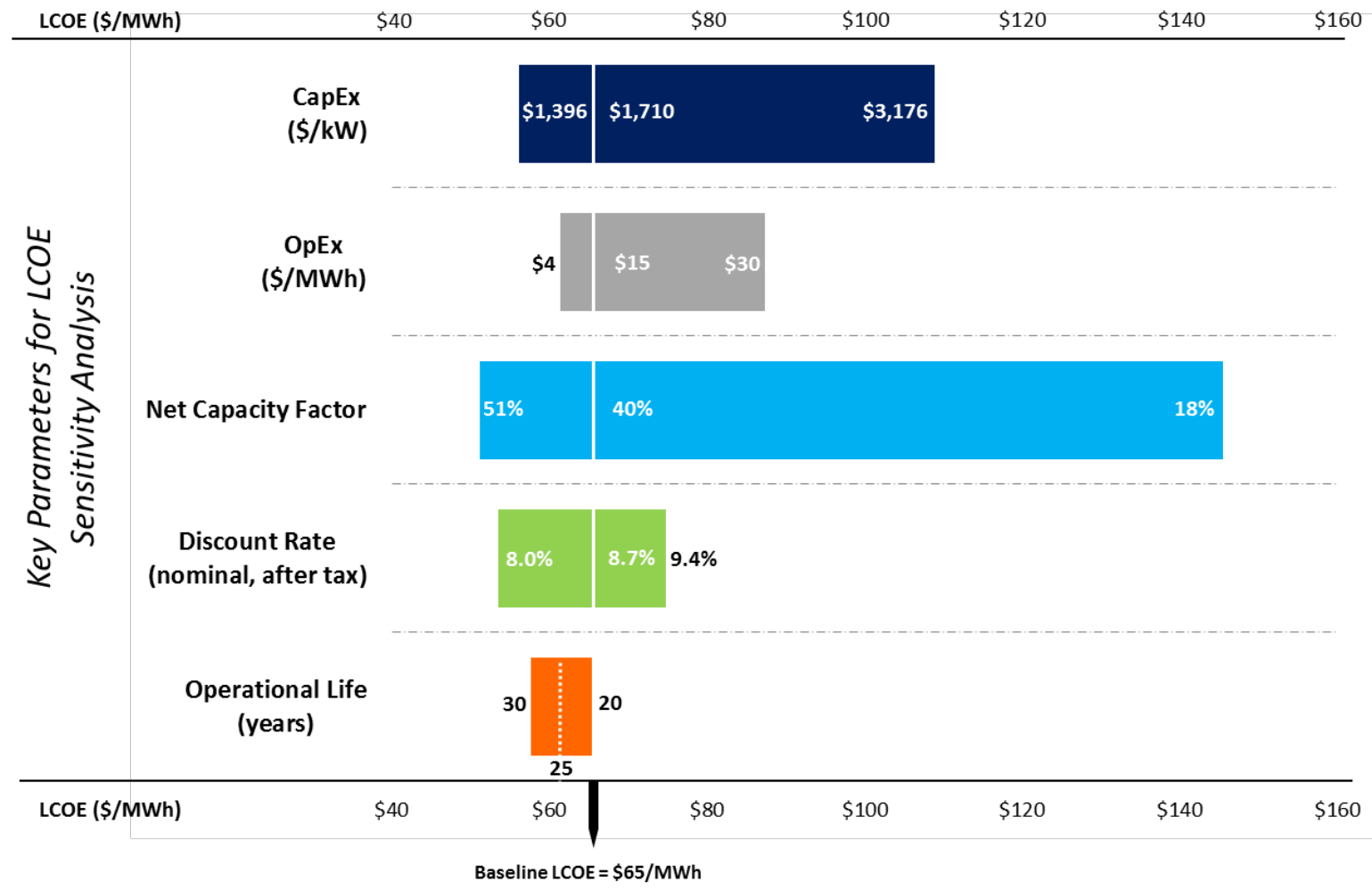

Figure ES3. Land-based wind plant assumptions and ranges for key LCOE input parameters

Source: NREL

Note: The reference LCOE represents the estimated LCOE for the NREL reference project. Changes in LCOE for a single variable can be understood by moving to the left or right along a specific variable. Values on the $\mathrm{x}$-axis indicate how the LCOE will change as a given variable is altered, assuming that all others are constant. For example, as capacity factor decreases toward $18 \%$, the LCOE shown on the $\mathrm{x}$-axis will increase accordingly to more than $\$ 140 /$ MWh. As the operational life for the reference project moves toward 30 years, the LCOE will decrease to nearly \$58/MWh. 


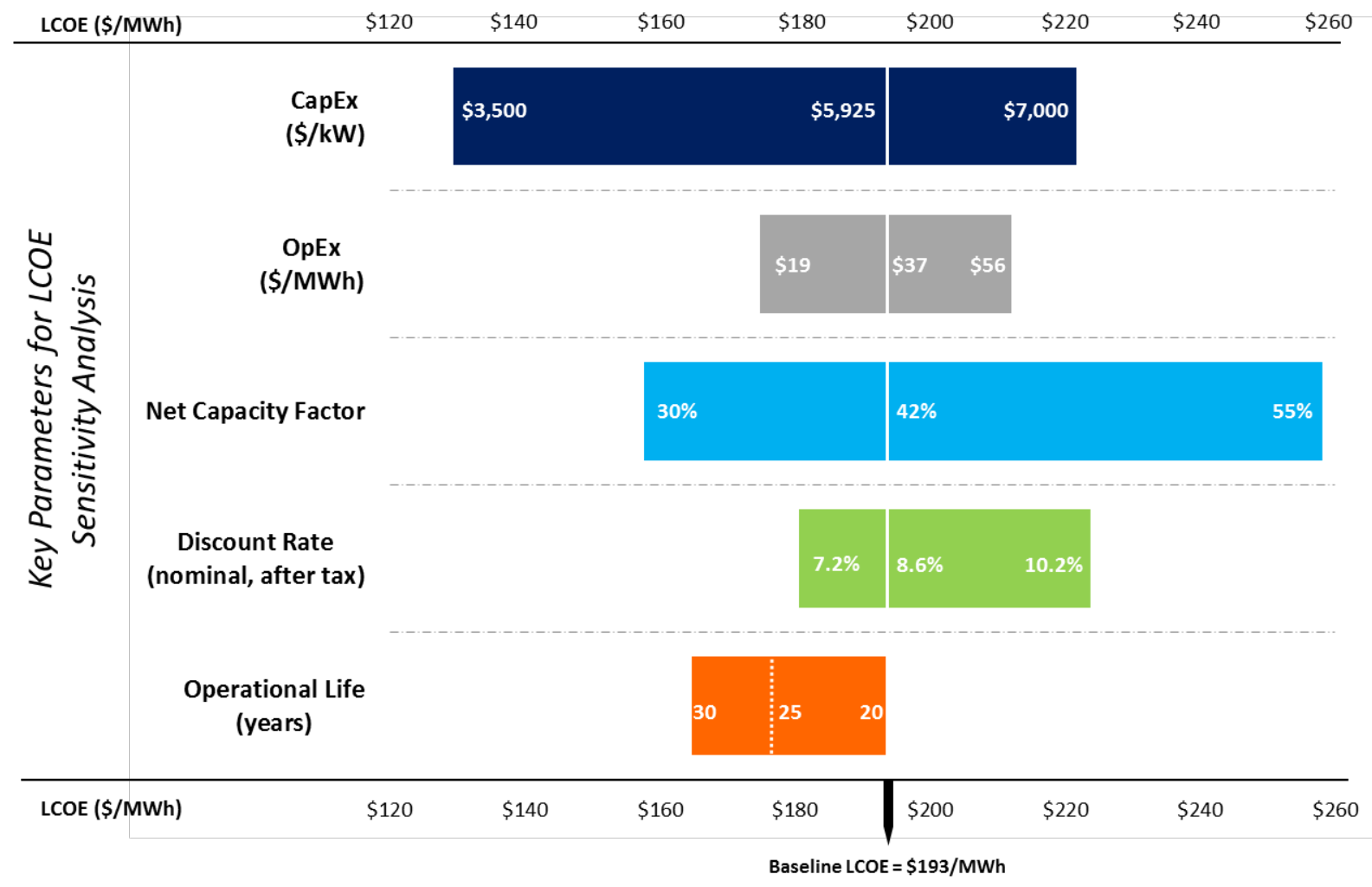

Figure ES4. Offshore wind plant assumptions and ranges for key LCOE input parameters

Source: NREL

From these results, researchers came to the following key conclusions:

- Final land-based wind plant LCOE estimates continue to show a downward trend from the 2010 Cost of Wind Energy Review (Tegen et al. 2012) to 2014. Offshore plant costs show similar cost reductions; however, the decrease in LCOE for the land-based projects can be attributed more to the turbine technology, and the offshore decreases to the maturity of the supply chain and changes in financing considerations of projects installed in Europe.

- Although the reference project LCOE for land-based installations was observed to be $\$ 65 / \mathrm{MWh}$, the range of land-based estimates from the single variable sensitivity analysis covers $\$ 51-\$ 146 / \mathrm{MWh}$.

- The reference project offshore estimate is $\$ 193 / \mathrm{MWh}$, with a single variable sensitivity range of $\$ 129-\$ 258 / \mathrm{MWh}$. This dramatic range is mostly caused by the large variation in CapEx $(\$ 3,500-\$ 7,000 /$ kilowatt $)$ and independently the net capacity factors $(30 \%-55 \%)$ reported by project developers.

- The sensitivity analysis shows that LCOE can vary widely based on changes in any one of several key factors; however, the variable with the most dramatic effect on LCOE is net capacity factor-which is the case for both land-based and offshore projects.

- National and regional supply curves illustrate that there is a significant range of LCOE across the country when wind turbine technology is matched with wind resource conditions suggesting that factors beyond least cost drive wind project realization. 


\section{Table of Contents}

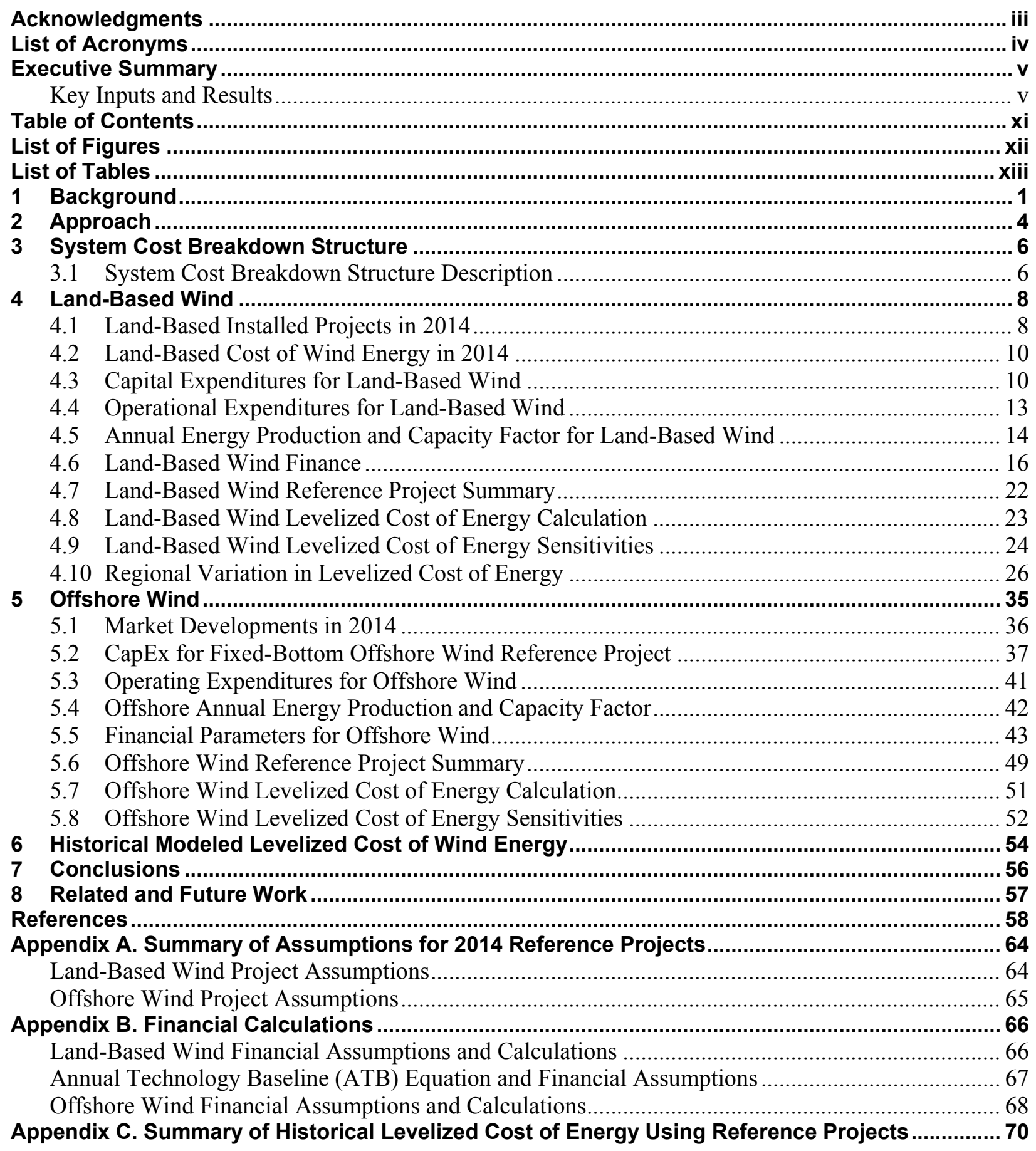




\section{List of Figures}

Figure ES1. Capital expenditures for the land-based reference wind plant project....................................vii

Figure ES2. Capital expenditures for the offshore reference wind plant project .................................... viii

Figure ES3. Land-based wind plant assumptions and ranges for key LCOE input parameters ..................ix

Figure ES4. Offshore wind plant assumptions and ranges for key LCOE input parameters ...................... $\mathrm{x}$

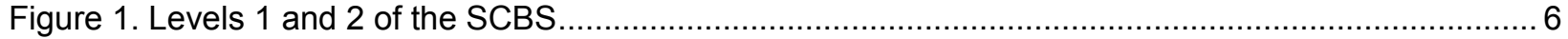

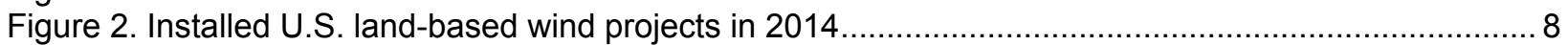

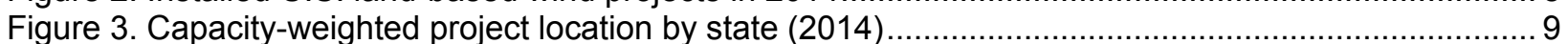

Figure 4. Capacity-weighted OEM supplier, by percentage (2014) ................................................. 9

Figure 5. Capital expenditures for the land-based wind reference project .......................................... 11

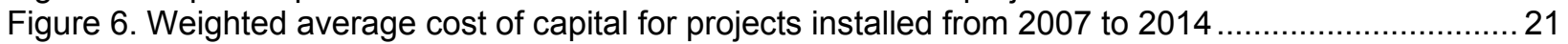

Figure 7. Component-level cost breakdown for the 2014 land-based wind reference project ................... 24

Figure 8. Sensitivity of land-based wind LCOE to key input parameters ............................................. 25

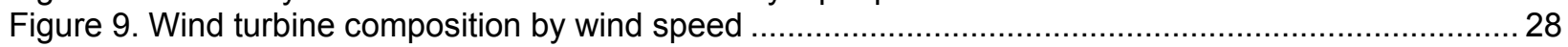

Figure 10. Power curves for five representative wind turbines ........................................................ 29

Figure 11. U.S. land-based wind resource supply curve with 2014 U.S. project locations ...................... 30

Figure 12. West region land-based wind supply curve with 2014 U.S. project locations ......................... 31

Figure 13. Interior region land-based wind supply curve with 2014 U.S. project locations ....................... 32

Figure 14. Great Lakes region land-based supply curve with 2014 U.S. project locations ....................... 32

Figure 15. Southeast region land-based supply curve with 2014 U.S. project locations.......................... 33

Figure 16. Northeast region land-based supply curve with 2014 U.S. project locations ......................... 33

Figure 17. Reported capital costs for offshore wind projects in \$2014 (includes full record from 1990) .... 37

Figure 18. Comparison of water depth and distance from shore of the offshore reference site and the

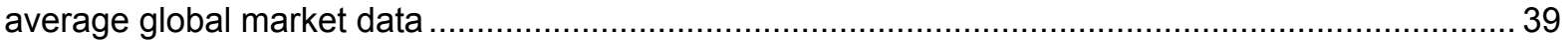

Figure 19. Capital expenditures for the 2014 offshore wind reference project ..................................... 40

Figure 20. Cost breakdown for the 2013 offshore wind reference project........................................... 52

Figure 21. Sensitivity of offshore wind LCOE to key input parameters ............................................ 53

Figure C1. Historical land-based wind plant LCOE as calculated by NREL, including the U.S. Department

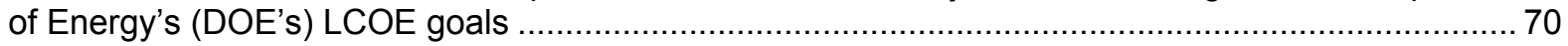

Figure C2. Historical offshore wind plant LCOE as calculated by NREL, including DOE's LCOE goals ... 71 


\section{List of Tables}

Table ES1. Summary of the Land-Based Reference Project Using 1.94-MW Turbines ............................vi

Table ES2. Summary of the Fixed-Bottom Offshore Reference Project Using 3.39-MW Turbines ..............vi

Table 1. Summary of Inputs and Reference Project LCOE for 2014 Land-Based Installations ................. 10

Table 2. Land-Based LCOE and CapEx Breakdown ................................................................... 12

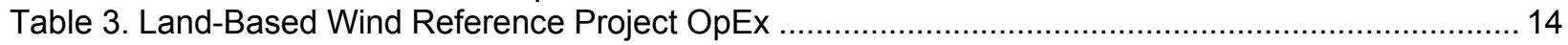

Table 4. Reference Land-Based AEP Input Assumptions ..................................................................... 14

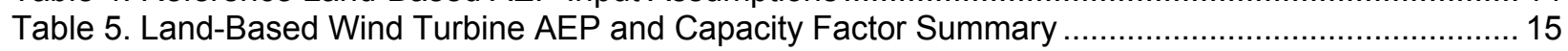

Table 6. Merchant/Merchant Hedge Projects Completed in 2014 ................................................... 17

Table 7. Tax Equity and Debt for New and Existing Wind Projects ..................................................... 18

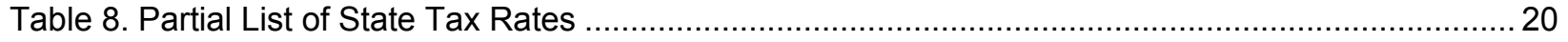

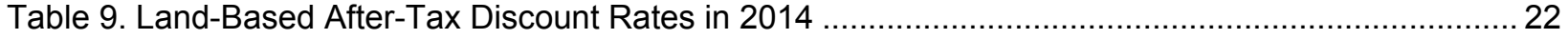

Table 10. Land-Based After-Tax Fixed Charge Rates in 2014 ....................................................... 22

Table 11. Land-Based Reference Project Assumptions Summary ...................................................... 23

Table 12. Land-Based Wind Reference Project LCOE Cost Breakdown .............................................. 24

Table 13. Five Representative Wind Turbines Based on 2014 Wind Turbine and Annual Average Wind

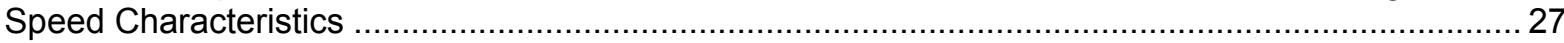

Table 14. Summary of Inputs and Results for the Fixed-Bottom Offshore Wind Project ........................ 35

Table 15. Comparison of Effects of Fixed-Bottom Offshore Reference Wind Project to Global Market Data

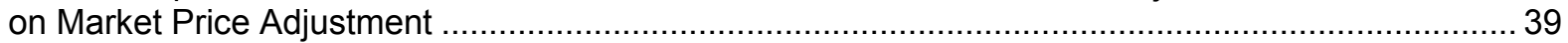

Table 16. Fixed-Bottom Offshore LCOE Component Cost Breakdown ................................................. 41

Table 17. Fixed-Bottom Reference Offshore AEP Input Assumptions ............................................... 42

Table 18. Offshore Wind Turbine AEP and Capacity Factor Summary ................................................. 43

Table 19. Location of Offshore Projects, 2012-2015 ................................................................... 44

Table 20. Offshore Project Risk Categories and Mitigation Strategies................................................. 46

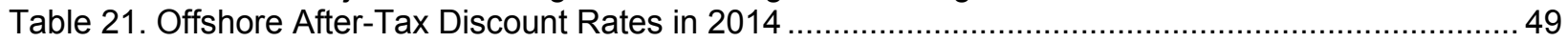

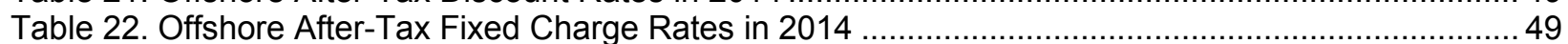

Table 23. Fixed-Bottom Offshore Reference Project Assumptions Summary .......................................50

Table 24. Fixed-Bottom Offshore Wind LCOE and Reference Project Cost Breakdown ......................... 51

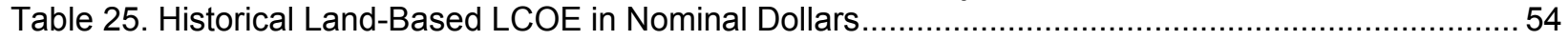

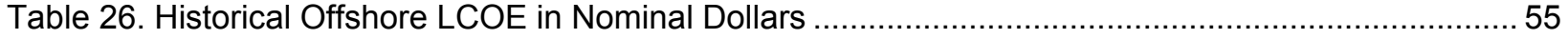

Table 27. Range of LCOE for U.S. Land-Based and Offshore Wind in 2013 .....................................56

Table A1. Comprehensive List of Assumptions for 2014 Land-Based Reference Project COE ............... 64

Table A2. Comprehensive List of Assumptions for 2014 Offshore Reference Project COE ..................... 65

Table B1. Scenario \#1 (IEA Structure) and Present Value of Depreciation Calculations $(d=8.7 \%) \ldots \ldots . . .66$

Table B2. Scenario \#2 (Partnership Flip Structure) and Present Value of Depreciation Calculations ( $d=$

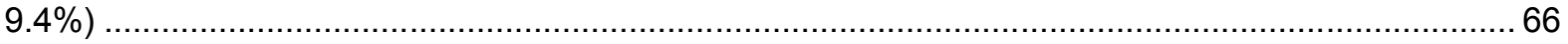

Table B3. Scenario \#3 (Tax/Cash Equity with Back-Leverage) and Present Value of Depreciation Calculations $(d=8.0 \%)$

Table B4. Summary of Annual Technology Baseline-Specific Terms Used in the Supply Curve Analysis 67

Table B5. Summary of ATB-Specific Financial and Present Value Depreciation Calculations $(d=8.9 \%) 68$

Table B6. Scenario \#1 (Equity with Back-Leverage) and Present Value of Depreciation Calculations $(d=$

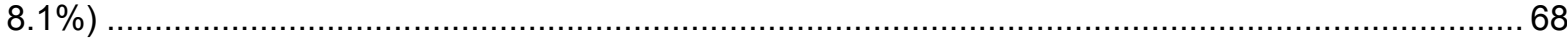

Table B7. Scenario \#2 (Nonrecourse Project Finance) and Present Value of Depreciation Calculations ( $d$

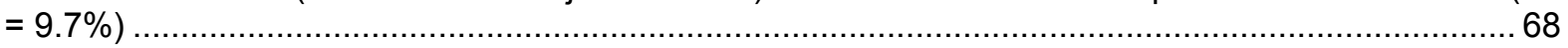

Table B8. Scenario \#3 (Balance Sheet Finance) and Present Value of Depreciation Calculations $(d=$ $7.2 \%)$

Table C1. Historical Land-Based Wind Plant LCOE as Calculated by NREL ....................................... 70

Table C2. Historical Land-Based Average Wind Plant Turbine Specifications....................................... 70

Table C3. Historical Offshore Wind Plant LCOE as Calculated by NREL …........................................ 71

Table C4. DOE's Cost Goals for Land-Based and Offshore Wind Power ............................................. 71 


\section{Background}

This report evaluates the levelized cost of energy (LCOE) for land-based and offshore wind projects in the United States. LCOE is a metric used to assess the cost of electric generation and the total plant-level impact from technology design changes, which can be used to compare costs of all types of electricity generation. Although different methodologies exist to calculate LCOE; the primary method used for this analysis is fully described in A Manual for the Economic Evaluation of Energy Efficiency and Renewable Energy Technologies (Short et al. 1995). ${ }^{1}$

In 2015, the National Renewable Energy Laboratory (NREL) expanded on Short's work by publishing the Annual Technology Baseline (ATB) (Blair et al. 2015) and the Standard Scenarios Annual Report (Sullivan et al. 2015). The ATB study provides a summary of current and projected future cost and performance of primary electricity generation technology in the United States, including renewable technologies. These cost and performance estimates are used in the Regional Energy Deployment System (ReEDS) model to create a set of standard scenarios for future U.S. electric sector evolution that will improve transparency of critical input assumptions and modeling methodologies.

This report, in conjunction with the ATB report, provides an update to the 2013 Cost of Wind Energy Review (Moné et al. 2015) and a look at the 2014 wind LCOE, turbine costs, financing, and market. The 2014 report included the following five tasks:

- Estimating the LCOE for the reference land-based wind project located in a Midwestern or "interior" site in the United States in 2014

- Estimating the regional variation in LCOE using a series of five wind turbines, based on the reference land-based wind tubine, and geographically unique wind profiles to estimate AEP

- Estimating the LCOE for the reference fixed-bottom U.S. offshore wind project reflecting projects currently in late-stage development on the North Atlantic Coast

- Conducting sensitivity analyses showing the range of effects basic LCOE variables could have on the levelized cost of wind energy for land-based and offshore wind power plants

- Representing NREL's calculated historical LCOE for land-based and fixed-bottom offshore wind plants.

This report addresses a number of assumptions and cost variables, but it does not include the full spectrum of drivers that affect wind energy prices. For example, it does not consider policy incentives (such as the production tax credit [PTC]), ${ }^{2}$ factors from underlying economic conditions (such as an economic recession), the cost of building long-haul interstate transmission, or potential integration costs. These important variables can significantly impact wind power costs by reducing total costs, adding expenditures, delaying projects, or halting projects altogether. Nevertheless, their exclusion is consistent with past economic analyses conducted by NREL (Lantz et al. 2012, Tegen et al. 2012) and others (Bloomberg New Energy Finance [BNEF] 2012, Lazard 2014),

\footnotetext{
${ }^{1}$ For an overview of cost-of-energy calculators and models, see Gifford et al. (2011).

${ }^{2}$ For further information, read Implications of a PTC Extension on U.S. Wind Deployment (Lantz et al. 2014).
} 
because LCOE is not traditionally defined as a measure of all societal costs and benefits associated with power generation resources.

The standard ATB LCOE equations can be simplified for each technology, which for wind results in the following equation used to calculate LCOE:

$$
\mathrm{LCOE}=\frac{(\mathrm{CapEx} \times \mathrm{FCR})+\mathrm{OpEx}}{\left(\mathrm{AEP}_{\text {net }} / 1,000\right)}
$$

where:

$$
\begin{aligned}
& \mathrm{LCOE}=\text { levelized cost of energy }(\$ / \text { megawatt-hour }[\mathrm{MWh}]) \\
& \mathrm{FCR}=\text { fixed charge rate }(\%) \\
& =\frac{d(1+d)^{n}}{(1+d)^{n}-1} \times \frac{1-(T \times P V d e p)}{(1-T)} \\
& \text { CapEx }=\text { capital expenditures }(\$ / \text { kilowatt }[\mathrm{kW}]) \\
& \mathrm{AEP}_{\text {net }}=\text { net average annual energy production }(\mathrm{MWh} / \text { megawatt }[\mathrm{MW}] / \text { year [yr]) } \\
& =\quad \mathrm{MW}_{n e t} \times 8,760 \times C F_{n e t} \\
& \mathrm{OpEx}=\text { operational expenditures }(\$ / \mathrm{kW} / \mathrm{yr}) \\
& =\quad L L C+O P E R+M A I N \\
& d \quad=\quad \text { discount rate (weighted average cost of capital [WACC]) }(\%) \\
& n \quad=\quad \text { economic operational life }(\mathrm{yr}) \\
& T \quad=\quad \text { effective tax rate }(\%) \\
& \text { PVdep }=\text { present value of depreciation }(\%) \\
& C F_{n e t}=\text { net capacity factor }(\%) \\
& L L C=\text { annual levelized land lease cost }(\$ / \mathrm{kW} / \mathrm{yr}) \\
& \text { OPER = pretax levelized operation cost (operation and maintenance }[\mathrm{O \& M}] \text { ) } \\
& (\$ / \mathrm{kW} / \mathrm{yr}) \\
& M A I N=\text { pretax levelized maintenance cost }(\mathrm{O} \& \mathrm{M})(\$ / \mathrm{kW} / \mathrm{yr}) .
\end{aligned}
$$


The first three basic inputs into the LCOE equation - capital expenditures (CapEx), operational expenditures (OpEx), and annual energy production (AEP) — enable this equation to capture system-level impacts from design changes (e.g., taller wind turbine towers). The fourth basic input - a fixed charge rate (FCR) - represents the amount of revenue required to pay the carrying charges $^{3}$ as applied to the CapEx on that investment during the expected project life on an annual basis. ${ }^{4}$ For this analysis, the life of a wind project is assumed to be 20 years. All analysis and LCOE results are in constant 2014 dollars throughout the report unless otherwise noted.

The following sections of this report define the approach to calculating the LCOE following the system cost breakdown structures (SCBSs) to organize data and provide a common terminology across varying technologies. The report describes each component of the LCOE equation (such as CapEx, OpEx, AEP, and FCR), the market context, and a range of data for typical U.S. wind projects in 2014. In this 2014 Cost of Wind Energy Review, the authors first define the 2014 LCOE components for a land-based reference project using an installed weighted average turbine sized at $1.94 \mathrm{MW}$, which was the average nameplate capacity installed in the United States in 2014. Next, the authors describe the 2014 LCOE components for an offshore wind reference project using 3.39-MW offshore turbines, which is the average nameplate capacity installed globally in 2014 .

\footnotetext{
${ }^{3}$ Carrying charges include the return on debt, return on equity, taxes, and depreciation.

${ }^{4}$ The FCR does not allow for detailed analysis of specific financing structures; however, these structures can be represented through the use of a WACC as the discount rate input.
} 


\section{Approach}

The 2014 Cost of Wind Energy Review applies a similar approach as the 2010, 2011, and 2013 reports (Tegen et al. 2012, Tegen et al. 2013, Moné et al. 2015). The authors used a number of data sources and models in NREL's estimation of the cost of wind energy. All models and data have, at some point, been tested, documented, and verified within NREL, other national laboratories, universities, and industry to ensure that the methodology and tools are as accurate as possible. For land-based wind technology calculations, the United States installed over 4,800 MW of new projects in 2014 , bringing the total cumulatively installed capacity to over $65,800 \mathrm{MW}{ }^{5}$ The available data from these wind projects provided a large sample of empirical data on plant costs and performance. In contrast, no commercial offshore wind technology has been deployed in the United States at the time of this study, and the market data supporting offshore cost of wind energy estimates are limited to international projects and proposed U.S. projects.

In addition to historical market data, the authors employed models to estimate disaggregated plantlevel cost components. Therefore, detailed data are provided on the individual components that make up CapEx, OpEx, and estimated AEP for the reference projects defined here. Given the market and model data available, the general approach to estimating the levelized cost of wind energy includes:

1. Evaluating market conditions and data for projects that have been installed in the United States in a given year, to understand total installed project cost, AEP, operating costs, and representative turbine technology. The primary sources for these data are the American Wind Energy Association (AWEA) database ${ }^{6}$ and the U.S. Department of Energy's (DOE's) Annual Wind Technologies Market Report data set (Wiser and Bolinger 2015). Representative turbine characteristics (i.e., rating, rotor diameter, and hub height) are taken as absolute averages. Accordingly, the LCOE estimates reflect average market conditions to the extent possible.

2. Evaluating market conditions and data for projects that have been installed in Europe and Asia when considering offshore wind technology in a given year, because no U.S. projects have been installed to date, to understand total installed project cost expenditures, AEP, OpEx, and representative turbine technology. The primary source for these data is NREL's internal Offshore Wind Database (OWDB) (NREL 2013) and the 2014-2015 U.S. Offshore Wind Technologies Market Report (Smith et al. 2015).

3. Supplementing available market data with modeled data based on a representative or reference project that reflects technology and project parameters for a given year. Principally, NREL's wind turbine design Cost and Scaling Model (Fingersh et al. 2006, Maples et al. 2010) is used to estimate the capital cost and AEP of a project based on turbine rated capacity, rotor diameter, hub height, and a representative wind resource. This model uses scaling relationships at the component level (e.g., blade, hub, generator, and tower) developed with curve-fit industry data, published scaling models, and turbine models developed through the WindPACT studies (e.g., Malcolm and Hansen 2006) that reflect component-specific and often nonlinear relationships between size and cost (see

\footnotetext{
${ }^{5}$ Note that not all of the data for these projects are publicly available.

${ }^{6} \mathrm{http}: / /$ stats.awea.org, accessed April 6, 2015.
} 
Appendix C in Tegen et al. 2012). The use of this model provides additional componentlevel details for turbines (with user-defined parameters) and plants.

4. Combining the market data and modeled data described above to estimate the primary elements necessary to calculate LCOE (i.e., CapEx, OpEx, AEP, and FCR) and provide details about wind technology costs and performance that are aligned with market data but reported at a more detailed resolution.

This approach is useful in that the reference project is described with a level of detail that is based on technology specifications, preserving market conditions. Relying on modeled data for disaggregated component-level and energy production estimates, however, also introduces a degree of uncertainty in some LCOE input variables. Model uncertainty is introduced principally in two areas:

- Modeled installed capital cost tends to overestimate market data that are influenced by factors not captured by the model (e.g., the relative value of the U.S. dollar, industry profit margins, foreign labor costs, underlying market conditions, and changes in warranty terms or servicing agreements that are wrapped into turbine supply agreements) that are included in the market-based CapEx that would be included in a commercial wind project.

- The modeled $\mathrm{AEP}_{\text {net }}$ estimate relies on estimated total losses across the reference project; however, production losses are, in reality, site- and technology-dependent, and measurements for individual projects are not available.

To address these two uncertainties, model estimates for CapEx and capacity factor are adjusted to reflect market data by applying two terms: a "market price adjustment" factor and a generic "losses" term. These terms apply global adjustment factors (coefficients) to cost and production estimates that account for the myriad of factors that are not explicitly modeled, but that can have a significant cumulative effect. Continued efforts to improve the fidelity of NREL's bottom-up models are expected to result in greater confidence associated with individual component estimates and plant-level production; however, it is unlikely that differences between market and modeled data will ever be fully resolved. 


\section{System Cost Breakdown Structure}

As domestic and global wind markets mature, data for component-level costs are increasingly available. To manage and organize this component-level cost data, NREL has developed an SCBS for land-based and offshore wind projects. This structure provides the ability to view the components of a wind plant at varying degrees of cost detail. A broad overview of plant costs is shown from the top down. From the bottom up, one can see how individual component costs are grouped into systems and how their costs roll up to higher-level costs until the plant level is reached. The SCBS deconstructs the total expenditures of a wind project down to six levels and includes more than 300 components.

\subsection{System Cost Breakdown Structure Description}

The wind SCBS provides structured and consistent breakdowns of a wind project into smaller, more specific components. ${ }^{7}$ It provides a standardized approach to characterizing total lifetime expenditures for wind projects at the component level, including both physical costs (e.g., materials, labor, and equipment) and financial costs (e.g., insurance during construction, profit, and carrying charges). Each descending level of the SCBS hierarchy represents an increasingly detailed look at the project components. For example, total lifetime expenditures can be deconstructed into two "level 1" components: CapEx and OpEx. CapEx can be further deconstructed into three "level 2" components: turbine, balance of system (BOS), and financial costs (see Figure 1). The sum of the costs across all components at a given level should equal the cost of the components in the level above them provided that all fields have data. For example, the sum of turbine costs, BOS costs, and financial costs (level 2) should equal the CapEx for a given project (level 1).

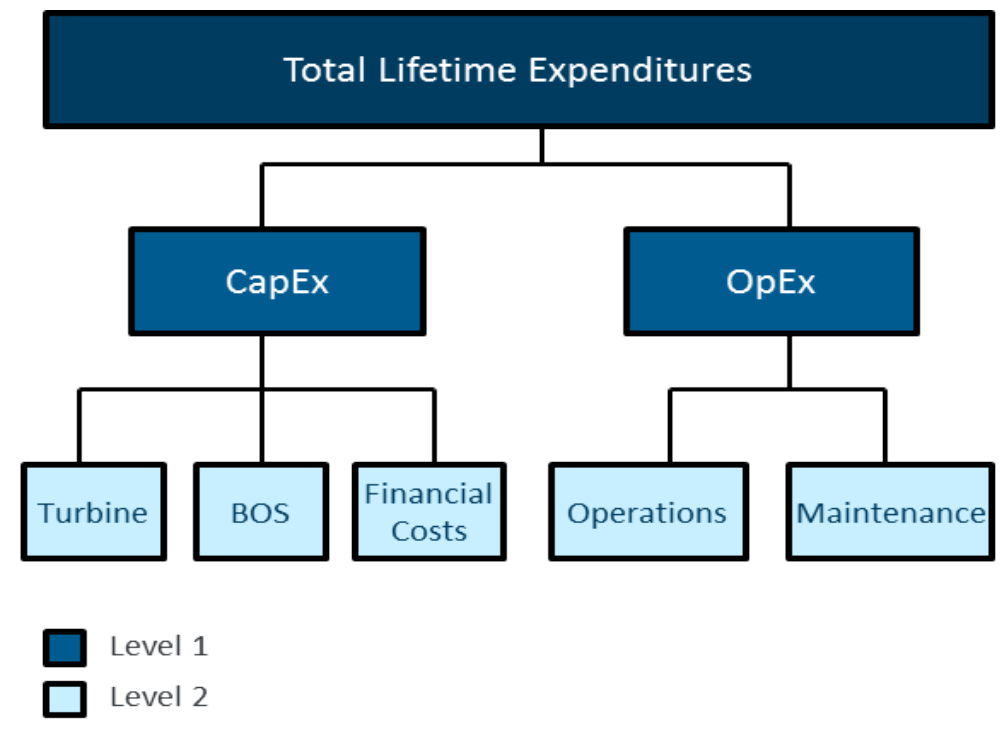

Figure 1. Levels 1 and 2 of the SCBS

Source: NREL

\footnotetext{
${ }^{7}$ Although the SCBS is similar to a work breakdown structure, it serves a different purpose. A work breakdown structure is typically process- or product-oriented, whereas the SCBS is cost-oriented, with a focus on representing the components of a project that contribute to the capital and operational expenditures.
} 
The wind SCBS is hierarchical and defines both the position of a component within the system and its relationship to other components. In this way, the SCBS effectively defines the bounds for the categories of data, reduces the chance of double counting or making inappropriate comparisons, and standardizes terminology to improve communication.

To be applicable and useful across a broad range of wind projects, an SCBS is designed to represent a generic project with line items to capture many possible technology configurations. Despite best efforts to define a generic SCBS, there are several reasons to expect it will not apply perfectly to any single project in the real world:

- Projects have different components depending on technical specification (e.g., a directdrive wind turbine will not have a gearbox).

- There are many permutations of possible contractual relationships for a project, ranging from a single engineering, procurement, and construction (EPC) contract to a full multicontract approach, in which a sponsor might manage all contracts internally.

- Based on previous experience in collecting data from industry, various entities use different approaches for tracking the expenditures involved in a given wind project. The SCBS provides a consistent approach to organize the industry data and eliminate variations in how the industry groups its subcomponent data.

An SCBS deconstructs the total expenditures of a wind project down to six levels and includes more than 300 components. The various elements of CapEx and OpEx follow the SCBS categories throughout this report. The full detailed explanation of the wind SCBS, including descriptions of each component category, is included in Appendix E and F of the 2013 Cost of Wind Energy Review (Moné et al. 2015). 


\section{Land-Based Wind}

The land-based wind reference project was derived from representative characteristics of wind plants in DOE's 2014 Wind Technology Market Report (Wiser and Bolinger 2015). Reference project wind turbine and component costs are based on the most common turbine design installed in the United States in 2014. This type of turbine rests on a standard spread-foot foundation design and incorporates a three-stage planetary/helical gearbox feeding a high-speed asynchronous generator. The reference project wind regime is generally equivalent to a moderate wind resource site in the interior region of the United States, generally considered to reach from Minnesota to Texas.

\subsection{Land-Based Installed Projects in 2014}

In 2014, the U.S. wind power market installed 50 projects totaling 4,854 MW (Wiser and Bolinger 2015). Figure 2 shows the size and location of the installed projects in the five regions outlined in the 2014 Wind Technology Market Report (Wiser and Bolinger 2015). The majority of turbines were installed in Texas. As shown in Figure 3, 74\% of all turbines were installed in the interior region of the United States in 2014.

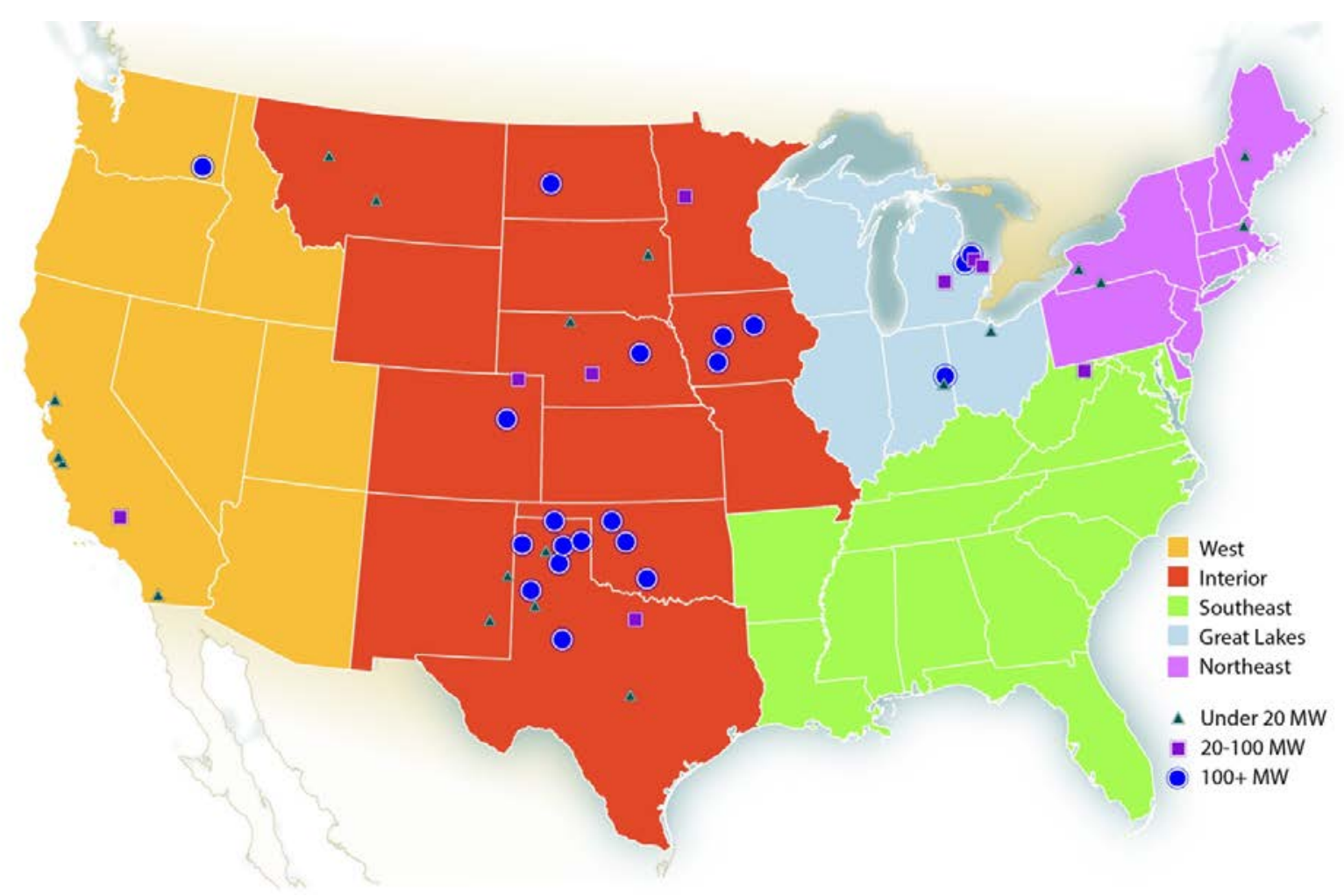

Figure 2. Installed U.S. land-based wind projects in 2014

Source: NREL 


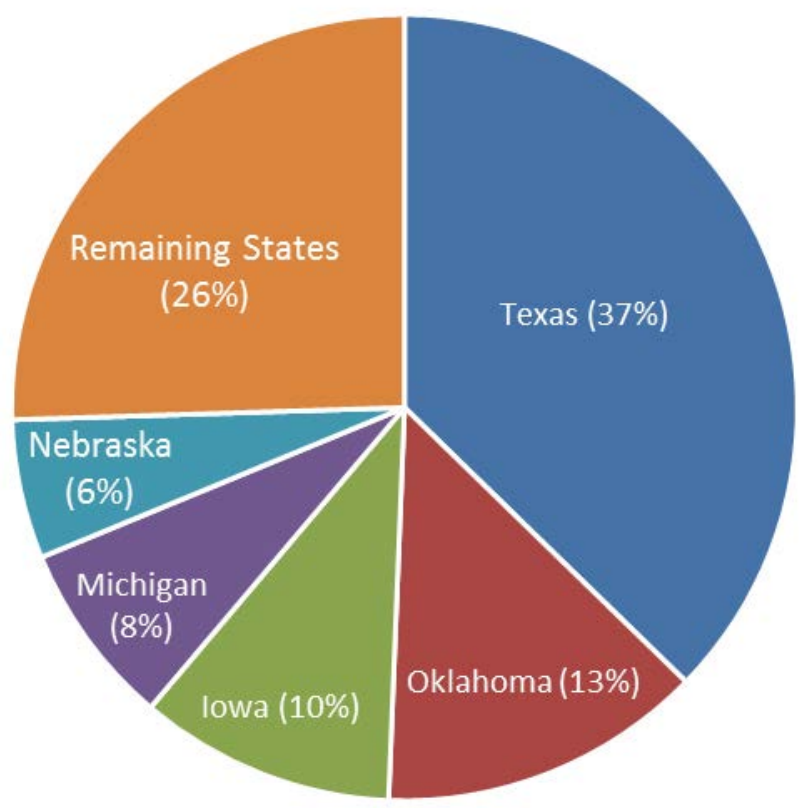

Figure 3. Capacity-weighted project location by state (2014)

Source: NREL

Although there are dozens of global turbine manufacturers, the U.S. market is dominated by three in particular: GE, Siemens, and Vestas. Figure 4 shows that GE installed the most capacity in the United States in 2014, as it has for the past decade, at $60 \%$ of total capacity-weighted installation. In 2014, Siemens installed 26\%, and Vestas installed 12\%, with all other turbines being installed by the remaining $2 \%$ of original equipment manufacturers (OEMs).

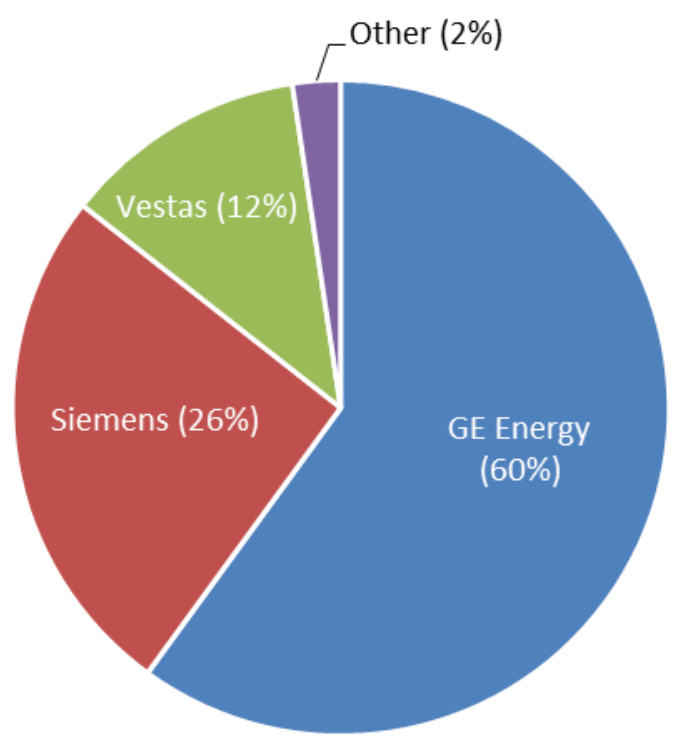

Figure 4. Capacity-weighted OEM supplier, by percentage (2014)

Source: NREL 


\subsection{Land-Based Cost of Wind Energy in 2014}

The land-based wind reference project was created to calculate the LCOE and used representative characteristics of all 50 wind projects installed in 2014. The land-based wind reference project consists of 103 1.94-MW turbines (200 MW total installed capacity). The capacity-weighted average CapEx ${ }^{8}$ of all 2014 installed wind projects was calculated to be $\$ 1,710 / \mathrm{kW}$, with total pretax OpEx at $\$ 51 / \mathrm{kW} / \mathrm{yr}$. The U.S. land-based reference project AEP was calculated to be 3,466 $\mathrm{MWh} / \mathrm{MW} / \mathrm{yr}$, which is a net capacity factor of $39.6 \%$. Accordingly, these values were ascribed to the land-based reference project. Given these inputs, as well as the additional variables considered to reflect the reference project summarized in Table 1 , the resulting LCOE is $\$ 65 / \mathrm{MWh}$.

Table 1. Summary of Inputs and Reference Project LCOE for 2014 Land-Based Installations

\begin{tabular}{|c|c|c|c|}
\hline $\begin{array}{c}\text { Data } \\
\text { Source }^{a}\end{array}$ & & $\begin{array}{c}\text { 1.94-MW } \\
\text { Land-Based } \\
\text { Turbine } \\
(\$ / k W)\end{array}$ & $\begin{array}{c}\text { 1.94-MW } \\
\text { Land-Based } \\
\text { Turbine } \\
\text { (\$/MWh) }\end{array}$ \\
\hline Model & Turbine capital cost & 1,221 & 35 \\
\hline Model & BOS & 345 & 10 \\
\hline Model & Financial costs & 154 & 3 \\
\hline Market & Market price adjustment ${ }^{b}$ & -10 & 0 \\
\hline Market & CapEx & 1,710 & 49 \\
\hline Market & Annual OpEx (\$/kW/yr) & 51 & 15 \\
\hline Market & Real FCR (\%) & \multicolumn{2}{|c|}{10.3} \\
\hline Model & $\mathrm{AEP}_{\text {net }}(\mathrm{MWh} / \mathrm{MW} / \mathrm{yr})$ & \multicolumn{2}{|c|}{3,466} \\
\hline Model & Net capacity factor (\%) & \multicolumn{2}{|c|}{39.6} \\
\hline Calculated & TOTAL LCOE (\$/MWh) & \multicolumn{2}{|c|}{65} \\
\hline
\end{tabular}

${ }^{a}$ Sources are listed in the relevant sections of this report related to the specific cost components.

${ }^{\mathrm{b}}$ The market price adjustment is the difference between the modeled cost and the price paid for the average project in the 2014 market.

\subsection{Capital Expenditures for Land-Based Wind}

The weighted-average CapEx data are published annually by DOE, with the latest version being the 2014 Wind Technologies Market Report (Wiser and Bolinger 2015). The analysis conducted here applies the NREL wind turbine design Cost and Scaling Model (Fingersh et al. 2006, Maples et al. 2010) to estimate component-level costs that were calibrated to the market-based total cost estimates from the data set used by Wiser and Bolinger (2015). The current modeling approach uses national averages in a project-specific site analysis and recent trends for variables not captured in the modeling necessitated calibration. NREL has developed a bottom-up model that

\footnotetext{
${ }^{8}$ CapEx costs represent the total cost of building a plant and do not include project-specific financing or escalation costs, which can vary with risk perception, construction schedules, inflation expectations, and other factors. Instead, the financing and escalation costs are represented by the FCR in modeling described in Section 4.6.
} 
associates physical parameters with cost estimates. Although this approach slightly overpredicts the total cost, it can provide greater fidelity in component cost and relative component cost change with the size of the turbine.

Figure 5 illustrates the breakdown of CapEx for the NREL land-based reference project. In the figure, the CapEx component percentages highlighted in shades of green capture the turbine capital cost, percentages highlighted in blue capture the BOS share of capital costs, and components highlighted in purple capture the financial capital costs. For information on the assumptions and inclusions of the individual components, see Tegen et al. (2012), Maples et al. (2010), and Fingersh et al. (2006).

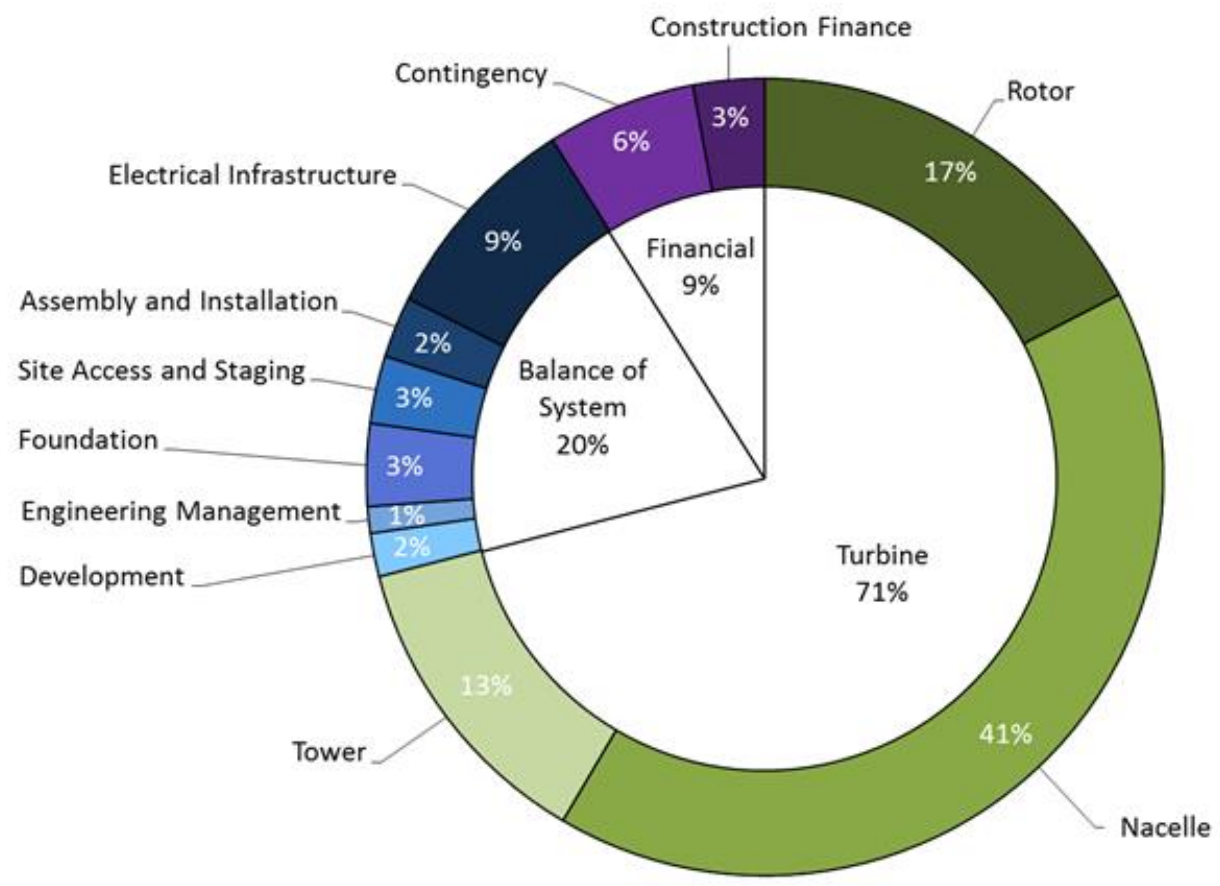

Figure 5. Capital expenditures for the land-based wind reference project

Source: NREL

Table 2 summarizes the costs for individual components (including their contribution to LCOE) for average turbine characteristics used in the reference project, based on a project that uses 1.94MW turbines. Data sources for this table are described in Appendix A. 
Table 2. Land-Based LCOE and CapEx Breakdown

\begin{tabular}{|c|c|c|}
\hline & $\begin{array}{c}\text { 1.94-MW Land- } \\
\text { Based Turbine } \\
(\$ / \mathrm{kW})\end{array}$ & $\begin{array}{c}\text { 1.94-MW Land- } \\
\text { Based Turbine } \\
\text { (\$/MWh) }\end{array}$ \\
\hline Rotor Module & 300 & 9 \\
\hline Blades & 182 & 5 \\
\hline Pitch assembly & 68 & 2 \\
\hline Hub assembly & 50 & 1 \\
\hline Nacelle Module & 706 & 20 \\
\hline Nacelle structural assembly & 153 & 4 \\
\hline Drivetrain assembly & 240 & 7 \\
\hline Nacelle electrical assembly & 282 & 8 \\
\hline Yaw assembly & 40 & 1 \\
\hline Tower Module & 215 & 6 \\
\hline TURBINE CAPITAL COST & 1,221 & 35 \\
\hline Development Cost & 30 & 1 \\
\hline Engineering Management & 19 & 1 \\
\hline Foundation & 58 & 2 \\
\hline Site Access and Staging & 47 & 1 \\
\hline Assembly and Installation & 43 & 1 \\
\hline Electrical Infrastructure & 149 & 4 \\
\hline BALANCE OF SYSTEM & 345 & 10 \\
\hline Market Price Adjustment & -10 & 0 \\
\hline Construction Financing Cost & 50 & 1 \\
\hline Contingency Fund & 104 & 3 \\
\hline FINANCIAL COSTS & 144 & 4 \\
\hline TOTAL CAPITAL EXPENDITURES & 1,710 & 49 \\
\hline
\end{tabular}

Wind turbine costs for projects installed in 2014 ranged from $\$ 850 / \mathrm{kW}$ to $\$ 1,120 / \mathrm{kW}$ for utilityscale wind projects (Wiser and Bolinger 2015). Because of CapEx variability, estimates for the turbine component costs were established using the NREL wind turbine design Cost and Scaling Model (Fingersh et al. 2006, Maples et al. 2010). BOS costs were estimated using NREL's landbased BOS model, which utilizes scaling relationships and costs from detailed data obtained through a major EPC firm active in the wind industry. These relationships provided a basis for understanding the underlying impacts of turbine component designs on the BOS costs, costs associated with different terrains, site access, and regional labor costs, as well as the impacts of innovative BOS concepts and differences. Construction financing was estimated at 3\% of CapEx, which is consistent with industry reporting. 
Because of CapEx variability, a market price adjustment was applied to bring the CapEx cost in line with the reported industry average. The market price adjustment accounts for fluctuations in component costs, profit margins, foreign exchange rates, supply chain constraints, and other market conditions that can vary from project to project.

\subsection{Operational Expenditures for Land-Based Wind}

OpEx for this project, which are considered on an annual basis, reflect estimates from 147 projects installed to date, of which 64 of the projects have 2014 data included in the analysis (Wiser and Bolinger 2015). OpEx costs are generally expressed in two categories: (1) OPER or fixed operations, which include discrete, known operations costs (e.g., scheduled plant maintenance, rent, land lease costs, taxes, utilities, and insurance payments) that typically do not change depending on how much electricity is generated; and (2) MAIN or variable OpEx, which include unplanned maintenance of either the plant or turbine, planned turbine maintenance, and other costs that may vary throughout the project life depending on how much electricity is generated. For simplicity, annual OpEx can be converted to a single term and expressed as either dollars per kilowatt per year $(\$ / \mathrm{kW} / \mathrm{yr})$ or dollars per megawatt-hour $(\$ / \mathrm{MWh})$. This analysis uses the dollarsper-kilowatt-per-year convention.

The OPER values reported to be $\$ 23 / \mathrm{kW} / \mathrm{yr}$ include land lease costs at $\$ 8 / \mathrm{kW} / \mathrm{yr}$, estimated from NREL's Jobs and Economic Development Impact (JEDI) model. Annual MAIN estimates are calculated from recent estimates of operating costs for projects built since 2000 . Wiser and Bolinger (2015) reported a pretax average MAIN value of $\$ 28 / \mathrm{kW} / \mathrm{yr}$ that generally incorporates the costs of wages and materials associated with maintaining the turbines of a facility, but likely excludes other elements such as general operations, insurance, taxes, and depreciation. ${ }^{9}$ A report by Cohen et al. (2008) uses the term "levelized replacement costs," which supports the major turbine components and replacement costs that go into the MAIN estimates.

OPER and MAIN bring the total pretax OpEx to $\$ 51 / \mathrm{kW} / \mathrm{yr}$ and are summarized in Table 3. It should be noted that, given the scarcity and unpredictable quality of the data, OpEx can vary substantially among projects (Wiser and Bolinger 2015), and the data presented here may not fully represent the challenges that OpEx present to the wind power industry. In addition, researchers across NREL and other laboratories in the wind industry have worked together over the past year to validate the $\$ 51 / \mathrm{kW} / \mathrm{yr}$ calculation and support these pricing levels; further information is located in the Wind Vision: A New Era for Wind Power in the United States report (DOE 2015b).

\footnotetext{
${ }^{9}$ Alternatively, if expressed in dollars-per-megawatt terms, O\&M estimates in 2014 ranged from $\$ 5$ to $\$ 20 / \mathrm{MWh}$ (based on plants with a commercial operation date of 2010), with the 2014 O\&M baseline estimate of $\$ 9 / \mathrm{MWh}$ (Wiser and Bolinger 2015).
} 
Table 3. Land-Based Wind Reference Project OpEx

\begin{tabular}{|lcc|}
\hline Operations (OPER) & $\begin{array}{c}1.94-M W \\
\text { Land-Based } \\
\text { Turbine }\end{array}$ & $\begin{array}{c}1.94-M W \\
\text { Land-Based } \\
\text { Turbine }\end{array}$ \\
\hline Land lease cost & $\$ 15 / \mathrm{kW} / \mathrm{yr}$ & $\$ 5 / \mathrm{MWh}$ \\
\hline Maintenance (MAIN) & $\$ 8 / \mathrm{kW} / \mathrm{yr}$ & $\$ 2 / \mathrm{MWh}$ \\
\hline OpEx & $\$ 28 / \mathrm{kW} / \mathrm{yr}$ & $\$ 8 / \mathrm{MWh}$ \\
\hline
\end{tabular}

\subsection{Annual Energy Production and Capacity Factor for Land-Based Wind}

The AEP for this analysis was computed using the NREL wind turbine design Cost and Scaling Model (Fingersh et al. 2006, Maples et al. 2010). The model computes annual energy capture and other related factors, such as capacity factor, for a wind project that is specified by generic input parameters (Table 4). These input parameters have been chosen as default values to be held constant for the annual LCOE calculations, allowing the differences in turbines and financing, not project variability, to influence the results. The input parameters can be grouped into three general categories: turbine parameters, wind resource characteristics, and losses.

Table 4. Reference Land-Based AEP Input Assumptions

\begin{tabular}{|lc|}
\hline \multicolumn{2}{|c|}{ Turbine Parameters } \\
\hline Turbine rated power $(\mathrm{MW})$ & 1.94 \\
\hline Turbine rotor diameter $(\mathrm{m})$ & 99.4 \\
\hline Turbine hub height $(\mathrm{m})$ & 82.7 \\
\hline Maximum rotor tip speed $(\mathrm{m} / \mathrm{s})$ & 80 \\
\hline Tip-speed ratio (TSR) at maximum coefficient of power $\left(\mathrm{C}_{\mathrm{p}}\right)$ & 8 \\
\hline Drivetrain design & Geared \\
\hline Rotor peak $\mathrm{C}_{\mathrm{p}}$ & 0.47 \\
\hline & \\
\hline Annual average wind speed at 50-m height $(\mathrm{m} / \mathrm{s})$ & 7.25 \\
\hline Weibull K & 2 \\
\hline Shear exponent & 0.143 \\
\hline Elevation (meters above sea level) & 450 \\
\hline \multicolumn{1}{|c|}{ Losses } & \\
\hline Losses (i.e., array, energy conversion, and line) & $15 \%$ \\
\hline Availability & $98 \%$ \\
\hline
\end{tabular}




\subsubsection{Turbine Parameters}

Turbine parameters are characteristics that are specific to the turbine and independent of the wind characteristics. These parameters consist not only of turbine size (such as rated power, rotor diameter, and hub height), but also of turbine operating characteristics (such as coefficient of power $\left[\mathrm{C}_{\mathrm{p}}\right]$, maximum tip speed, maximum tip-speed ratio (TSR), and drivetrain design). Because the three-stage planetary/helical gearbox with a high-speed asynchronous generator style drivetrain topology dominates the U.S. market, this type of drivetrain was selected for the baseline turbines used in this analysis. For specific approaches regarding additional turbine parameters (e.g., power curves), see the 2010 Cost of Wind Energy Review (Tegen et al. 2012).

\subsubsection{Wind Resource}

The average wind speed can vary from project to project across the United States. The annual average wind speed chosen for the reference project analysis was 7.25 meters per second $(\mathrm{m} / \mathrm{s})$ at 50 meters $(\mathrm{m})$ above ground level $(7.79 \mathrm{~m} / \mathrm{s}$ at a hub height of $82.7 \mathrm{~m})$. This wind speed is intended to be generally indicative of the wind regime for projects installed in moderate-quality sites in the interior region of the United States (from Minnesota to Texas). An elevation of $450 \mathrm{~m}$ above sea level was used based on this concept of using a representative site that would have a similar altitude to a project located within the interior of the country. The elevation above sea level, coupled with a hub height of $82.7 \mathrm{~m}$, results in an average air density of $1.163 \mathrm{~kg} / \mathrm{m}^{3}$.

\subsubsection{Losses}

Although some losses can be affected by turbine design or wind characteristics, they are treated as independent of any other input in this simplified analysis. Types of losses accounted for here include array wake losses, electric collection and transmission losses (from the substation to the point of interconnection), and blade soiling losses, totaling $15 \%$. An availability of $98 \%$ was used, indicating that the wind project is ready to produce power between wind turbine cut-in and cut-out wind speeds $98 \%$ of the time. $\mathrm{AEP}_{\text {net }}$ is calculated by applying all losses to the gross AEP. The net capacity factor is the ratio of the power output over a given period of time. Historically, the net capacity factor has ranged from $18 \%-51 \%$ (Wiser and Bolinger 2015), meaning that the NREL estimate for the representative wind plant is within range. Table 5 shows the AEP, capacity factors, losses, and availability for the land-based reference turbine operating in 2014.

Table 5. Land-Based Wind Turbine AEP and Capacity Factor Summary

\begin{tabular}{|lc|}
\hline & $\begin{array}{c}\text { 1.94-MW Land- } \\
\text { Based Turbine }\end{array}$ \\
\hline Gross AEP (MWh/MW/yr) & 4,161 \\
\hline Gross capacity factor (\%) & 47.5 \\
\hline Losses and availability (\%) & 17 \\
\hline AEP $_{\text {net }}(\mathrm{MWh} / \mathrm{MW} / \mathrm{yr})$ & 3,466 \\
\hline Net capacity factor (\%) & 39.6 \\
\hline
\end{tabular}




\subsection{Land-Based Wind Finance}

The United States is now a recognized world leader for wind energy production, thanks to a capital infusion of more than $\$ 120$ billion in the last 15 years (AWEA 2014). Public policy has played a major role in the successful financing of wind energy projects, including renewable portfolio standards at the state level and tax incentives at the federal level, such as PTCs, investment tax credits (ITCs), and accelerated depreciation benefits. Section 1603 of the American Recovery and Reinvestment Act of 2009 introduced a program offering cash payments in lieu of tax credits for qualifying projects, and by the end of 2014, one-third of the entire U.S. fleet had been built with the Section 1603 program incentive payment (Settle 2015). Through the years of policy changes, developers and financiers have continued to advance financing approaches for wind energy.

NREL analyzed recent developments and trends in the U.S. land-based wind industry and used the results of the analysis to develop financing assumptions for the report's representative land-based wind project for 2014. By simplifying assumptions that might be found in a detailed cash flow analysis, such as tax considerations and a discount rate, an FCR is detailed and used to calculate the LCOE.

\subsubsection{Overview of U.S. Land-Based Wind Financing Trends}

In 2014, the wind industry rebounded considerably with the commissioning of 50 projects totaling 4,854 MW of new wind energy capacity that were likely committed and financed between late 2012 and early 2014. A blend of information that includes wind projects commissioned in 2014 and wind energy financing transaction fundamentals in 2014 for the representative wind project was used for this report.

Successful financing in the U.S. wind energy industry remains dependent primarily on tax credits. Historically, the PTC was the primary subsidy available for wind energy projects and currently provides a $2.3 \phi / \mathrm{kWh}$ incentive for the first 10 years of a wind project's operation. With the American Recovery and Reinvestment Act of 2009, wind energy projects could elect to receive an ITC instead of the PTC or elect to receive an equivalent cash payment in lieu of tax credits under the Section 1603 program. The ITC equals $30 \%$ of the eligible portion of a project's capital cost.

The Section 1603 program expired for wind energy at the end of 2012, and the production and ITC incentives expired again at the end of 2013. In mid-December 2014, a tax extenders bill retroactively extended both tax credits through the end of 2014 (about 2 weeks). Wind projects that had begun physical construction or invested at least $5 \%$ of project costs to meet a safe harbor requirement by the end of 2014 are eligible for the tax credits provided that the wind project is placed in service prior to January 1, 2017. Because of modern turbine efficiency considerations, most land-based wind projects opt for the PTC (Internal Revenue Service [IRS] 2015).

Beyond public policy-based tax credits and loan guarantees, a wind project becomes attractive for financing after obtaining a long-term (e.g., 20-year) power purchase agreement (PPA) with a creditworthy offtake, which becomes the basis for committed financing. The limited availability of PPAs in recent years, a decline in PPA pricing as natural gas prices have fallen, and the availability of ITCs and cash payments in lieu of tax credits have emboldened some wind developers to include a merchant element. Merchant sales are dependent on quantity and pricing at a given time on the open market and reflect more risk than that present in a long-term offtake 
agreement, making it difficult to secure financing because of the perceived project risk by financial parties.

A recent trend intended to bridge the gap between merchant risk and a long-term offtake agreement is the "synthetic PPA." A synthetic PPA is effectively a hedge contract with a third party that provides a collar on power pricing, thereby reducing project risk. If electricity from the wind project is sold below a benchmark price, the project gets paid the difference. If electricity is sold above a benchmark price, the counterparty gets paid the difference. Synthetic PPAs are found in deregulated markets where hedging counterparties are available and can help a wind project secure reasonable financing given a reduced risk profile over a strictly merchant operation (Marciano 2013). Demonstrating the importance of merchant wind plants, Table 6 lists the projects commissioned that have been identified as merchant, quasi-merchant, or merchant hedge (AWEA 2015), approximately $30 \%$ of all 2014 installed projects.

Table 6. Merchant/Merchant Hedge Projects Completed in 2014

\begin{tabular}{|lccc|}
\hline Project Name & $\begin{array}{c}\text { Project } \\
\text { Capacity } \\
\text { (MW) }\end{array}$ & Power Purchaser & Market \\
\hline Orangeville Wind & 9.7 & Quasi-Merchant & NYSERDA $^{\text {a }}$ \\
\hline Goldthwaite & 7.5 & Merchant & ERCOT $^{\text {b }}$ \\
\hline Panhandle Wind 1 & 218.3 & Merchant Hedge & ERCOT $^{\text {ER }}$ \\
\hline Miami & 288.6 & Merchant Hedge & ERCOT \\
\hline Fourmile Ridge & 40.0 & Merchant & PJM $^{c}$ \\
\hline Marsh Hill & 16.2 & Quasi-Merchant & NYSERDA \\
\hline Hereford 1 & 199.9 & Merchant Hedge & ERCOT \\
\hline Grandview 1 & 211.2 & Merchant Hedge & ERCOT \\
\hline Panhandle Wind 1 & 181.7 & Merchant Hedge & ERCOT \\
\hline Stephens Ranch 1 & 211.2 & Merchant Hedge & ERCOT \\
\hline Windthorst 2 & 68.0 & Merchant Hedge & ERCOT \\
\hline Total & $\mathbf{1 , 4 5 2 . 4}$ & & \\
\hline $\begin{array}{l}\text { a NYSERDA = New York State Energy Research and Development Authority } \\
\text { b ERCOT = Electric Reliability Council of Texas } \\
{ }^{\mathrm{c}} \text { PJM = PJM Interconnection }\end{array}$ & & \\
\hline
\end{tabular}

According to AWEA's annual report, financing for wind energy projects in 2013 and 2014 comprised a blend of tax equity and debt, as shown in Table 7 (AWEA 2015). 
Table 7. Tax Equity and Debt for New and Existing Wind Projects

\begin{tabular}{|lcc|}
\hline Year & $\begin{array}{c}\text { Tax Equity } \\
\text { (billion \$) }\end{array}$ & Debt (billion \$) \\
\hline 2013 & 3.1 & 2.4 \\
\hline 2014 & 5.8 & 2.7 \\
\hline Total & $\mathbf{8 . 9}$ & 5.1 \\
\hline
\end{tabular}

Industry sources report that most wind projects commissioned in 2014 were financed mainly with only tax equity and cash (sponsor) equity at the project level. Historically, a more traditional project finance structure for power generation might involve $60 \%$ long-term project debt and $40 \%$ equity (Lazard 2014); however, for wind projects the tax equity and permanent debt at the project level are effectively mutually exclusive. This condition is caused by the collapse of market consensus on the extent to which lenders, who are ahead of tax equity in the capital structure, should forbear from foreclosing on the project in a default scenario long enough for the tax equity investors to reach a target return.

A survey of industry professionals indicated that 29 wind deals were awarded in 2014 involving 19 tax equity investors, amounting to nearly 6,000 MW of wind and close to $\$ 5.8$ billion of tax equity. Sponsors generally prefer the well-understood partnership flip model (Martin 2015). Based on discussions with developers and financiers, NREL understands that tax equity comprises approximately $50 \%$ to $60 \%$ of the total capital structure for a typical wind project. This report looks at the effects of the partnership flip financing model and the effects on LCOE during the sensitivity analysis.

The remaining $45 \%$ of the capital structure — about $\$ 4.7$ billion for the industry - is from cash equity from the sponsor. For some projects, the sponsor's contribution may include some level of back-leverage debt. Back-leverage is essentially a loan to the sponsor secured by future cash flows from the project. Because the debt is not at the project level, though, the lender does not have a position that is ahead of tax equity in the capital structure. According to industry experts, fewer than half of the 2014 projects that were financed with tax equity also have back-leverage. For those that do, debt at the sponsor's level may be in the range of $40 \%$ to $75 \%$, whereas true equity from the sponsor may comprise $25 \%$ to $60 \%$ of the sponsor equity contributed to the project entity. For purposes of this report, the $60 \%$ traditional split debt and $40 \%$ equity was used to represent the back-leveraged contribution. The Chadbourne Cost of Capital: 2015 Outlook report identified \$1.8 billion in debt for 2014 wind energy projects (Martin 2015). Although the debt volume was relatively low and tax equity was primary for wind energy, nearly 100 banks played a role in infrastructure project finance in 2014 (Martin 2015). This report looks at the effects of the equity financing model and the impact on LCOE during the sensitivity analysis.

\subsubsection{Equity Yields and Debt Interest in 2014}

According to BNEF, after-tax yields for tax equity remain stable at roughly $8 \%$, plus or minus 50 basis points (bps) for unleveraged utility-scale wind projects (BNEF 2015). The Chadbourne report (Martin 2015) indicated stable tax equity yields in recent years, with upward pressure resulting from front-end fees and higher post-flip yield targets. For benchmark wind deals with 
leading sponsors, top-tier equipment, and long-term PPAs, the tax equity yields were confirmed at $8 \%$ plus or minus 50 bps (Martin 2015). Discussion with other industry experts has indicated that the after-tax, preflip yield is in the range of $7.25 \%$ to $8.50 \%$ - averaging an $8 \%$ yield — and about $50 \mathrm{bps}$ higher when the post-flip yield of $9 \%$ is considered. An after-tax yield of $8 \%$, with a range of $7.25 \%$ to $9.00 \%$ to represent the tax equity component cost of capital, was used for the analysis.

BNEF identifies debt yields at 200 bps over the London Interbank Offered Rate (LIBOR), with tenors in the 7- to 10-year range. Some banks are willing to extend loans with longer terms (out to 15 to 18 years) (BNEF 2015). The Chadbourne report indicated that highest-quality renewable energy projects were closed at 150 bps over LIBOR, while complex, aggressive deals and backleveraged debt approached 300 basis points over LIBOR (Martin 2015). With fees and a contracted hedge for LIBOR, the estimated cost of back-leveraged debt is in the range of $4.5 \%$ to $6.0 \%$, with an average of $5.5 \%$.

Sponsor equity target returns are opaque and wide-ranging. Based on discussions with industry participants, sponsor equity targets are often contemplated based on an overall project return of approximately $9 \%$ to $10 \%$. If a typical corporate composite tax rate is assumed, then a nominal after-tax yield of $11.0 \%$ for cash equity, with a possible range from less than $8 \%$ to $12 \%$ or higher, is expected. In a back-leveraged scenario, NREL used the assumption that the cheaper cost of debt allows the sponsor to push cash equity after-tax yields to $15.0 \%$.

\subsubsection{Discount Rate}

A number of different metrics can be used in the economic evaluation of wind energy. Typically, various financial terms, such as the cost of debt or equity, are implicitly captured in the discount rate, $d$, which is in turn used to estimate the cost of energy (COE). The cost of capital data collected and described in the preceding subsection gives a basis for discount rate assumptions for the representative wind project in 2014. Each actual project, however, has a unique risk profile, financing terms, and ownership structure. For this reason, a single discount rate representing the entire fleet of 2014 wind installations should be viewed cautiously and is illustrative of general market trends and conditions only.

For this analysis, the discount rate is calculated as the after-tax WACC and it is presumed that the reported yields for equity are after-tax yields and can be used directly in the WACC calculation in this analysis. The cost of debt as a value is also reported, but because interest on debt is tax deductible, an effective corporate marginal tax rate to determine an after-tax cost of debt for the discount rate calculation presented in this report is utilized.

In financial modeling, corporate tax rates are often presented as a composite, or effective, tax rate. This rate is calculated from a blend of the highest marginal corporate tax rate of $35 \%$ and an approximate average state corporate tax rate of $6 \%$. Because state taxes are deductible expenses on federal tax returns, the blended rate is represented as $35 \%+6 \% \times(100 \%-35 \%)=38.9 \%$.

Wind projects are organized as disregarded entities for tax purposes (i.e., no taxes are paid by the project entity). Taxes are paid further up the organizational structure at some corporate level, though. So-called double taxation occurs for these corporations when the shareholders also pay taxes on the corporation's net income. 
State tax rates are variable. For example, the tax rates in the 10 states with the most wind energy capacity are shown in Table 8.

Table 8. Partial List of State Tax Rates

\begin{tabular}{|cc|cc|}
\hline State & Tax Rate & State & Tax Rate \\
\hline Texas & $a$ & Illinois & $9.5 \%$ \\
\hline lowa & $12.0 \%$ & Minnesota & $9.8 \%$ \\
\hline California & $8.84 \%$ & Oregon & $7.6 \%$ \\
\hline Oklahoma & $6.0 \%$ & Colorado & $4.63 \%$ \\
\hline Kansas & $7.0 \%$ & Washington & a \\
\hline & & Average & $\mathbf{8 . 1 7 \%}$ \\
\hline
\end{tabular}

${ }^{a}$ Tax rates in Texas and Washington are based on gross receipts and do not translate effectively into a corporate tax rate that can be compared with other states.

As shown, in eight of the top 10 wind energy states, the average tax rate is more than $2 \%$ higher than the average state tax rate used in the nationally based calculation of composite tax rate. A toptier wind energy developer might employ an apportioned state tax rate representing more closely the specific states in which it operates. Discount rates are initially calculated in nominal after-tax dollars, and an estimate of inflation is used to calculate a discount rate in real after-tax dollars. If an investor targets a nominal $8 \%$ return in an environment with inflation at $2 \%$, the net return to the investor - the real after-tax return-is just under $6 \%$.

For the purposes of previous versions of this analysis and report, the inflation rate has been consistent with the U.S. Energy Information Administration's (EIA's) Annual Energy Outlook. The current edition of the Annual Energy Outlook, published in April 2015 and reflecting an outlook period of 2013 to 2040 , uses an average annual inflation rate of $\mathbf{2 . 0 \%}$ as measured by growth in the Bureau of Labor Statistics' Consumer Price Index (CPI) (Federal Reserve, 2015). This rate is consistent with the Federal Reserve's objective and yields on treasuries and is therefore relied on for this calculation of discount rate in real dollars (EIA 2015).

For the base case, the nominal discount rate was estimated using five primary financing structures and assumptions detailed in an International Energy Agency (IEA) Wind Task 26 report titled Wind Technology, Cost, and Performance Trends in Denmark, Germany, Ireland, Norway, the European Union, and the United States: 2007-2012 (Hand et al. 2015). The "national average" numbers are ranges shown in Figure 6 and reflect a blend of these five financing structures. 


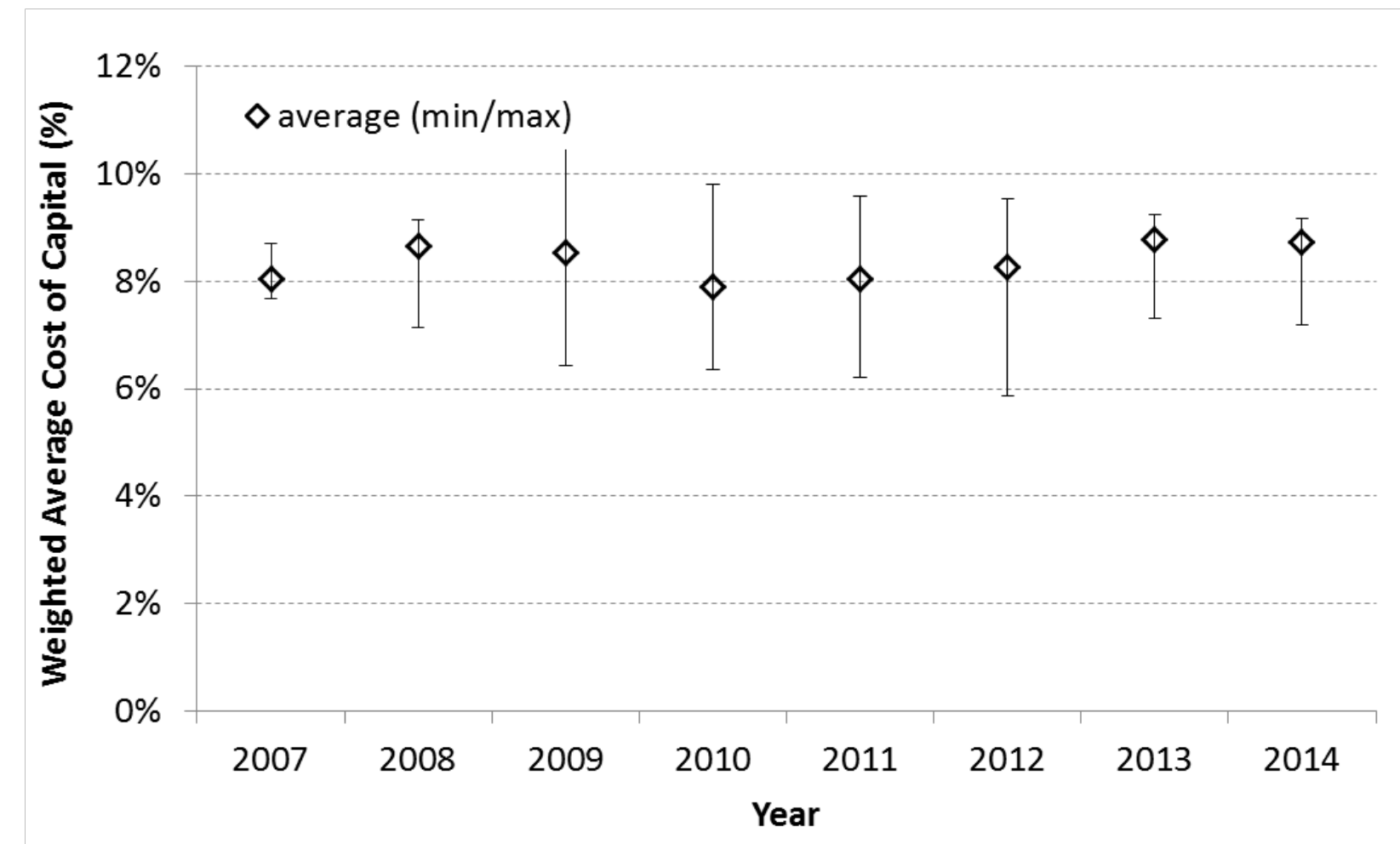

Figure 6. Weighted average cost of capital for projects installed from 2007 to $2014^{10}$

In addition, NREL conducted some sensitivity analyses using two primary 2014 financing structures. The first was under a partnership flip structure with 55\% tax equity, within a range of $50 \%$ to $60 \%$ tax equity. For the balance of equity, a primary scenario assumes cash equity from the sponsor (and sponsor partners) for $100 \%$ of the balance of project investment (ranging from $40 \%$ to $50 \%$ ). A secondary scenario assumes that the sponsor's contribution of equity to the capital structure includes back-leverage debt at $60 \%$ of the contribution, ranging from $40 \%$ to $75 \%$. The three scenarios for the 2014 analysis are shown in Table 9.

\footnotetext{
${ }^{10}$ Published by IEA in 2015 using Lawrence Berkeley National Laboratory (LBNL) 2007-2012 data. NREL updated the figure with LBNL 2013 and 2014 data.
} 
Table 9. Land-Based After-Tax Discount Rates in 2014

\begin{tabular}{|llc|}
\hline Scenarios & $\begin{array}{c}\text { Nominal } \\
\text { Discount } \\
\text { Rate }\end{array}$ & $\begin{array}{c}\text { Real } \\
\text { Discount } \\
\text { Rate }\end{array}$ \\
\hline Scenario \#1 (IEA Wind average structure) & $8.7 \%$ & $6.6 \%$ \\
\hline Scenario \#2 (Partnership flip structure) & $9.4 \%$ & $7.2 \%$ \\
\hline Scenario \#3 (Equity with back-leverage) & $8.0 \%$ & $5.9 \%$ \\
\hline
\end{tabular}

\subsubsection{Economic Evaluation Metrics}

To determine the LCOE for the 2014 representative project, an FCR is necessary. It represents an equal pretax revenue factor that must be recovered annually to pay for the capital investment and rate of return on capital. The FCR formula includes the present value of depreciation benefits available to wind projects.

U.S. wind projects in 2014 had the opportunity to benefit from accelerated depreciation (Modified Accelerated Cost Recovery System [MACRS]) and bonus depreciation. Bonus depreciation is ignored based on industry sources indicating that the bonus is a relatively small benefit and was not taken for many wind projects. A reasonable assumption for land-based wind projects is that $95 \%$ of the project capital cost is eligible for 5-year MACRS depreciation, and the balance of the project capital cost is eligible for 15 -year MACRS. In addition, the MACRS assumption is further simplified by assuming that $100 \%$ of the wind project cost basis is eligible for 5 -year MACRS.

Using the discount rates and present value of depreciation benefits just described and assuming a project life of 20 years, Table 10 presents the FCR for the three scenarios considered in this analysis. The details and calculations for these scenarios are summarized in Appendix B.

Table 10. Land-Based After-Tax Fixed Charge Rates in 2014

\begin{tabular}{|lcc|}
\hline Scenario & Nominal FCR & Real FCR \\
\hline Scenario \#1 (IEA Wind average structure) & $12.1 \%$ & $10.3 \%$ \\
\hline Scenario \#2 (Partnership flip structure) & $12.7 \%$ & $10.8 \%$ \\
\hline Scenario \#3 (Equity with back-leverage) & $11.4 \%$ & $9.7 \%$ \\
\hline
\end{tabular}

\subsection{Land-Based Wind Reference Project Summary}

Table 11 captures the full array of variables that reflect the land-based reference project as well as the values (for each variable) that underpin the basic LCOE inputs. The CapEx for the project is assumed to be nearly $\$ 342$ million, or $\$ 1,710 / \mathrm{kW}$. A contingency fund equal to $6 \%$ of CapEx, totaling \$20.8 million, is used to provide a liquid financial instrument setup to respond to "known unknown" costs that arise during construction, and OpEx is estimated at $\$ 15 / \mathrm{MWh}$. A project with 
a 20 -yr economic operating life is assumed with a nominal discount rate of $8.7 \%$ (the same as Scenario 1).

Table 11. Land-Based Reference Project Assumptions Summary

\begin{tabular}{|c|c|}
\hline \multicolumn{2}{|l|}{ General Assumptions } \\
\hline Project capacity (MW) & 200 \\
\hline Number of turbines & 103 \\
\hline Turbine capacity (MW) & 1.94 \\
\hline \multicolumn{2}{|l|}{ Site } \\
\hline Location & U.S. interior \\
\hline Elevation (meters above sea level) & 450 \\
\hline Layout & Grid \\
\hline Wind speed (m/s at a 50-m height above ground) & 7.25 \\
\hline Wind speed (m/s at a $80-\mathrm{m}$ height above ground) & 7.75 \\
\hline Net capacity factor & $39.6 \%$ \\
\hline \multicolumn{2}{|l|}{ Technology } \\
\hline Rotor diameter (m) & 99.4 \\
\hline Hub height (m) & 82.7 \\
\hline Gearbox & Three stage \\
\hline Generator & Asynchronous \\
\hline Foundation & Spread foot \\
\hline \multicolumn{2}{|l|}{ Cost } \\
\hline Capital cost (millions) & $\$ 342$ \\
\hline Contingency (6\%; millions) & $\$ 20.8$ \\
\hline OpEx (\$/MWh) & $\$ 15$ \\
\hline Discount rate (real) & $6.6 \%$ \\
\hline Discount rate (nominal) & $8.7 \%$ \\
\hline Economic operating life (years) & 20 \\
\hline FCR (real) & $10.3 \%$ \\
\hline
\end{tabular}

Note: The nominal discount rate may be generally equated with the WACC and is distinguished from the real discount rate in that it includes an inflation factor. The discount rate constitutes a principal input into the FCR, which allows for the estimation of capital recovery on an annualized basis.

\subsection{Land-Based Wind Levelized Cost of Energy Calculation}

Based on the NREL land-based baseline project inputs - CapEx, AEP, OpEx, and FCR - and using the LCOE equation, a land-based wind LCOE is computed to reflect the 2014 reference wind plant described previously. Table 12 summarizes the costs for the primary components (including 
their contribution to LCOE). Data sources for this table are included in Appendix A. Figure 7 provides a graphical representation of the land-based reference project LCOE by line item.

Table 12. Land-Based Wind Reference Project LCOE Cost Breakdown

\begin{tabular}{|c|c|c|}
\hline & $\begin{array}{c}\text { 1.94-MW } \\
\text { Land-Based } \\
\text { Turbine }\end{array}$ & $\begin{array}{c}\text { 1.94-MW } \\
\text { Land-Based } \\
\text { Turbine }\end{array}$ \\
\hline CapEx & $\$ 1,710 / \mathrm{kW}$ & \$49/MWh \\
\hline OpEx & $\$ 51 / \mathrm{kW} / \mathrm{yr}$ & \$15/MWh \\
\hline Net $7.25 \mathrm{~m} / \mathrm{s}$ AEP (MWh/MW/yr) & \multicolumn{2}{|c|}{3,466} \\
\hline Net capacity factor & \multicolumn{2}{|c|}{$39.6 \%$} \\
\hline FCR (real, after tax) & \multicolumn{2}{|c|}{$10.3 \%$} \\
\hline LCOE (\$/MWh) & \multicolumn{2}{|c|}{$\$ 65$} \\
\hline
\end{tabular}

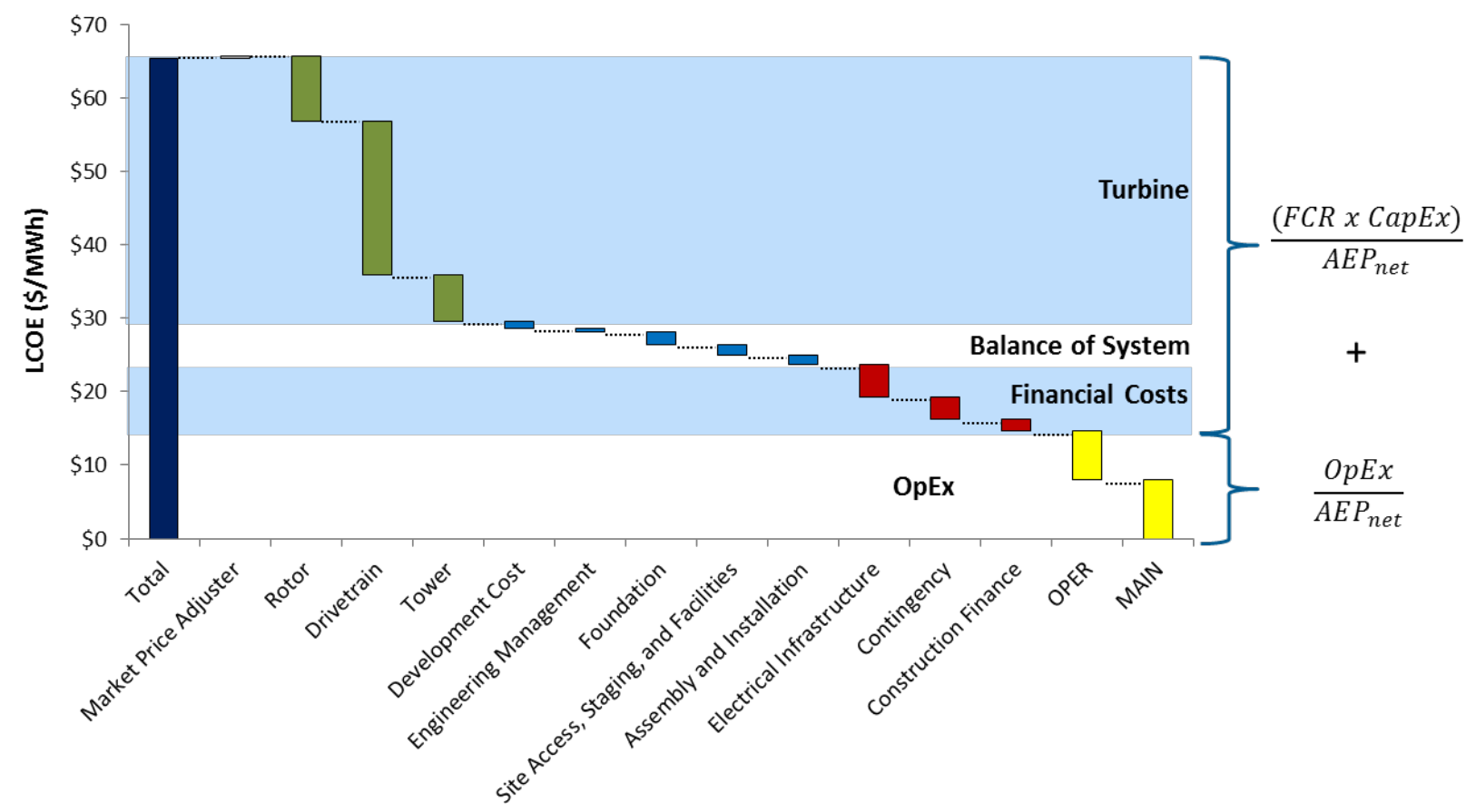

Figure 7. Component-level cost breakdown for the 2014 land-based wind reference project Source: NREL

\subsection{Land-Based Wind Levelized Cost of Energy Sensitivities}

The input parameters described previously reflect the land-based reference wind project; however, input parameters for a near-term wind project are subject to considerable uncertainty. As a result, it is beneficial to investigate how this variability may impact the LCOE. The sensitivity analysis shown in Figure 8 focuses on the basic LCOE inputs: CapEx, OpEx, capacity factor (a surrogate 
for AEP), and FCR. In Figure 10, though, FCR is broken into its principal elements - discount rate and economic operational lifetime. Sensitivities to these variables are tested across the ranges of market data reported in previous sections.

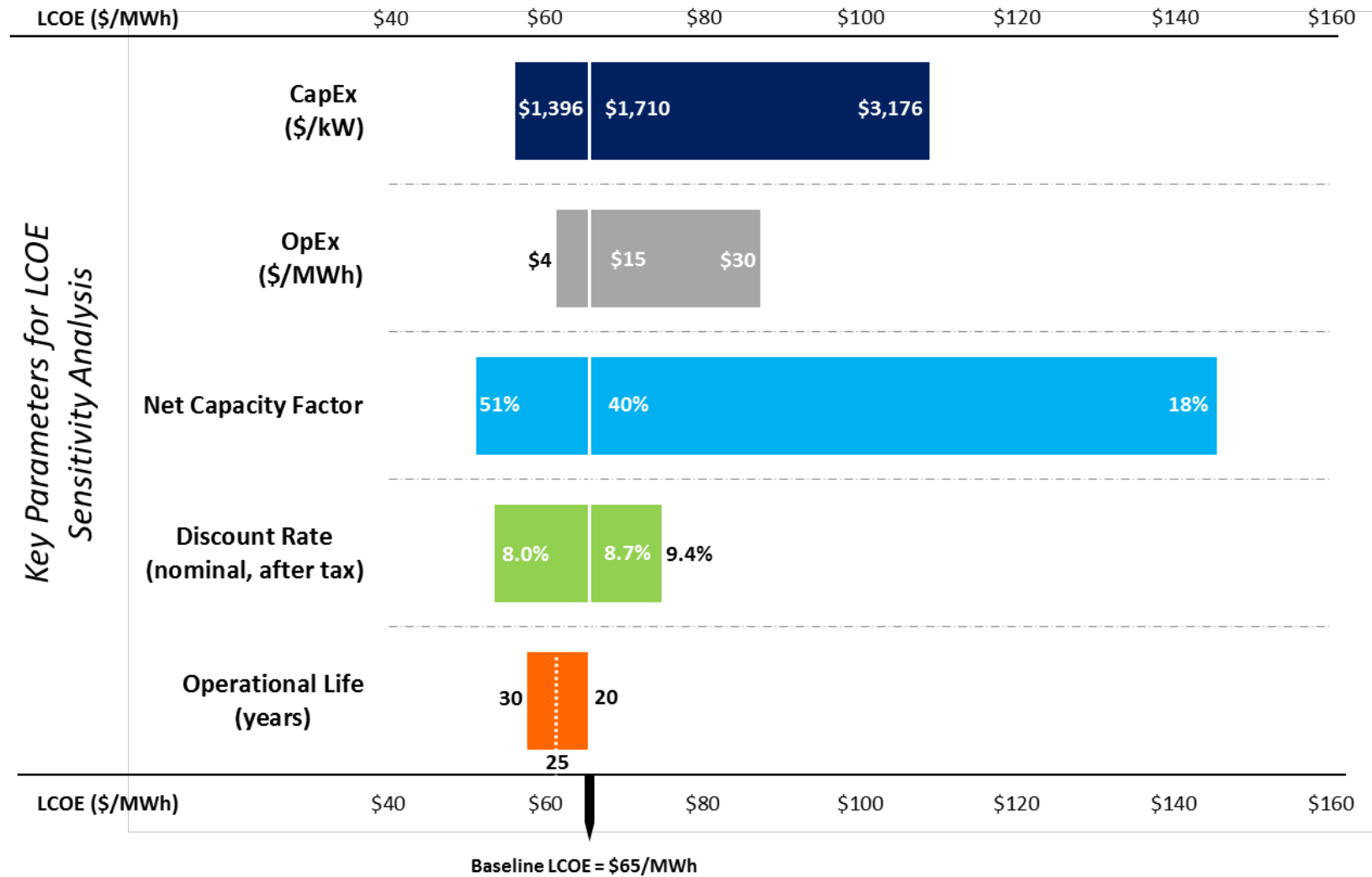

Figure 8. Sensitivity of land-based wind LCOE to key input parameters

Source: NREL

Note: The reference LCOE reflects a representative industry LCOE. Changes in LCOE for a single variable can be understood by moving to the left or right along a specific variable. Values on the $\mathrm{x}$-axis indicate how the LCOE will change as a given variable is altered and all others are assumed constant (i.e., remain reflective of the reference project).

Sensitivity analyses were conducted by holding all reference project assumptions constant and altering only the variable in question. Sensitivity ranges were selected to represent the highs and lows observed in the industry. This selection of ranges provides insight into how real-world ranges influence LCOE. The sensitivity analysis yields ranges in LCOE from a low of \$51/MWh to a high of $\$ 145 / \mathrm{MWh}$ - a low-to-high increase of nearly triple the lower bound. Within the ranges shown, CapEx and capacity factor are the two factors that appear to have the greatest impact on land-based wind LCOE; however, the capacity factor and discount rate appear to have the greatest influence with respect to decreasing the LCOE relative to the reference project.

Although the ranges provided here for the selected variables are grounded in actual 2014 plant costs and performance data, the high and low LCOE ranges should not be taken as absolutes. These variables are generally not independent, and it is unlikely for changes to occur only in a 
single variable. Moreover, each individual wind project has a unique set of characteristics. Accordingly, the sensitivities shown here are not universal. The next section explores regional variation in LCOE by correlating wind plant CapEx with turbine characteristics and wind resource profiles that affect capacity factor to address this limitation.

\subsection{Regional Variation in Levelized Cost of Energy}

An individual wind project will have unique costs associated with the site conditions, the project investors, the project ownership structure, and the specific contractual mechanisms developed to purchase equipment and install all aspects of the wind plant. Although this type of project-specific data is not readily available for a large sample of installed projects, estimated LCOE values can be useful to illustrate the range of project COE associated with primary drivers including wind resource conditions and turbine type. In this section of the report, supply curves illustrating estimated LCOE for all potential wind plant locations in the contiguous United States are shown. The corresponding geographic locations where wind plants were installed in 2014 are highlighted. These modeled estimates of wind project LCOE provide insights into the relative COE for projects installed in 2014 as well as the relative differences in COE among various geographic regions in the United States.

The approach used to estimate the LCOE at all potential wind plant locations in the contiguous United States, and land area exclusions, is based on Wind Vision (DOE 2015b) using wind plant characteristics representative of 2014 wind plant market data (Wiser and Bolinger 2015). In general, wind plant characteristics in terms of rotor diameter, machine rating, hub height, and capital cost are defined to represent the range of possible wind technology that could be implemented in the United States. Power curves associated with each turbine type are used to estimate the expected annual energy capture at all possible wind resource locations using longterm average hourly wind profiles. For each potential wind plant location, a cost to connect to nearby transmission infrastructure is estimated using the geographic distance between the site and the connection point. Expected annual O\&M costs, as well as project finance costs, are assumed constant across all wind plant locations. For each potential wind plant site, an LCOE is calculated using the definitions and equation in Appendix B (ATB section). This approach complements the sensitivity analysis in the prior section by providing a sense of the variation in LCOE associated with turbine technology, wind resource, and fluctuations in labor and material costs due to geographic locations in the United States.

\subsubsection{Wind Plant Characteristics}

To reflect the range of turbine technology that could be available in all potential wind resource locations throughout the U.S. market, data for nearly 2,500 wind turbines installed in 2014 were examined. Among wind turbines installed in 2014, the average machine rating was $1.94 \mathrm{MW}$ with a rotor diameter of $99.4 \mathrm{~m}$ (Wiser and Bolinger 2015) and a corresponding specific power of 250 Watts per square meter $\left(\mathrm{W} / \mathrm{m}^{2}\right)$. Each of the wind turbine locations for 2014 installations was associated with a long-term, annual average wind speed of $80 \mathrm{~m}$ (AWS Truepower 2015); a linear fit of specific power as a function of wind speed was developed. To estimate the LCOE for all potential wind plant locations in the United States, the linear fit was extrapolated to higher and lower wind speeds beyond that observed in 2014 wind plant market data. Five points along the line were selected corresponding to the $20^{\text {th }}, 50^{\text {th }}$, and $80^{\text {th }}$ percentiles of wind speed, as well as projects with wind speeds less than the $20^{\text {th }}$ percentile and greater than the $80^{\text {th }}$ percentile, for all 2014 
projects as well as upper and lower bounds of $10 \mathrm{~m} / \mathrm{s}$ and $5.5 \mathrm{~m} / \mathrm{s}$, respectively. Representative wind turbines were defined based on the corresponding specific power and wind speed for each of these five points as shown in Table 13; the reference land-based wind turbine is associated with the $50^{\text {th }}$ percentile of wind speed. The average machine rating was held constant across all representative wind turbines, and the hub height was maintained at $80 \mathrm{~m}$ to correspond with the available wind resource data. This approach results in turbine characteristics associated with site wind resource conditions corresponding to the population of wind turbines installed in 2014. This was done while also defining turbine characteristics associated with wind resource conditions higher and lower than the wind resource conditions in which the majority of projects were installed in 2014.

Table 13. Five Representative Wind Turbines Based on 2014 Wind Turbine and Annual Average Wind Speed Characteristics

\begin{tabular}{|c|c|c|c|c|c|}
\hline $\begin{array}{l}2014 \text { Wind } \\
\text { Resource } \\
\text { Conditions }\end{array}$ & $\begin{array}{c}<20^{\text {th }} \\
\text { Percentile } \\
\text { Average } \\
\text { Wind Speed }\end{array}$ & $\begin{array}{c}20^{\text {th }} \\
\text { Percentile } \\
\text { Average Wind } \\
\text { Speed }\end{array}$ & $\begin{array}{c}50^{\text {th }} \\
\text { Percentile } \\
\text { Average Wind } \\
\text { Speed }\end{array}$ & $\begin{array}{c}\mathbf{8 0}^{\text {th }} \\
\text { Percentile } \\
\text { Average Wind } \\
\text { Speed }\end{array}$ & $\begin{array}{l}>80^{\text {th }} \\
\text { Percentile } \\
\text { Average Wind } \\
\text { Speed }\end{array}$ \\
\hline Turbine Name & T200 & T232 & T250 & T261 & T325 \\
\hline $\begin{array}{l}\text { Wind Speed } \\
(\mathrm{m} / \mathrm{s})\end{array}$ & 5.5 & 6.78 & 8 & 8.76 & 10 \\
\hline $\begin{array}{l}\text { Specific Power } \\
\left(\mathrm{W} / \mathrm{m}^{2}\right)\end{array}$ & 200 & 232 & 250 & 261 & 325 \\
\hline $\begin{array}{l}\text { Machine } \\
\text { Rating (MW) }\end{array}$ & 1.94 & 1.94 & 1.94 & 1.94 & 1.94 \\
\hline $\begin{array}{l}\text { Rotor } \\
\text { Diameter (m) }\end{array}$ & 111.1 & 103.2 & 99.4 & 97.2 & 87.2 \\
\hline Hub Height (m) & 80 & 80 & 80 & 80 & 80 \\
\hline CapEx (\$/kW) & 1,756 & 1,675 & 1,640 & 1,621 & 1,542 \\
\hline OpEx (\$/kW/yr) & 51 & 51 & 51 & 51 & 51 \\
\hline $\begin{array}{l}\text { Capacity } \\
\text { Factor }^{a}\end{array}$ & $30.3 \%$ & $38.8 \%$ & $46.0 \%$ & $49.5 \%$ & $51.1 \%$ \\
\hline FCR (Real) ${ }^{b}$ & $10.1 \%$ & $10.1 \%$ & $10.1 \%$ & $10.1 \%$ & $10.1 \%$ \\
\hline
\end{tabular}

${ }^{\mathrm{a}}$ Capacity factor estimated using annual average wind speed, Weibull distribution with $\mathrm{K}=2$, and losses including availability of $16.7 \%$.

${ }^{\mathrm{b}}$ The FCR in this analysis is consistent with ATB (Blair et al. 2015) for use in subsequent analysis. Note that this FCR represents a nominal WACC of $8.9 \%$, which is very similar to the Scenario \#1 (WACC $=8.7 \%, \mathrm{FCR}=10.3 \%$ ) representation for the land-based reference plant $\mathrm{COE}$ analysis in prior sections.

These five different turbine types would result in a range of capital cost associated with the different turbine technologies. The capacity-weighted average CapEx of 2014 wind projects installed in the interior region of the United States was $\$ 1,640 / \mathrm{kW}$ (Wiser and Bolinger 2015). This value is associated with the average wind turbine characteristics at the $50^{\text {th }}$ percentile annual 
average wind speed. ${ }^{11}$ The land-based reference wind plant, which was discussed in previous sections, is based on a national average of both turbine characteristics and CapEx to create a theoretical project to track LCOE. The supply curve is geographically specific, and regional cost adders (in addition to the geographic wind speeds) are used to give variability to the CapEx for projects across the United States. The NREL Cost and Scaling Model (Fingersh et al. 2006, Maples et al. 2010) was used to estimate the impact on CapEx associated with changing the rotor size to reflect the range across the five representative wind turbines, as shown in Table 13. The difference in CapEx between the five representative turbines, $\$ 214 / \mathrm{kW}$, associated with a rotor size variation of $24 \mathrm{~m}$, compares favorably with similar estimates from MAKE Consulting (Barr et al. 2013) and Lawrence Berkeley National Laboratory (LBNL) (Wiser et al. 2012). These CapEx values represent wind turbine cost in locations with no significant logistical challenges or unusual siting conditions similar to the interior region of the United States. Expected annual average OpEx was assumed independent of wind turbine technology and consistent with assumptions described in Section 4.4. Similarly, project finance assumptions were held constant for all wind plant LCOE estimates.

The report assumes that a single turbine type, T325, would be installed at all sites with annual average wind speeds of $10 \mathrm{~m} / \mathrm{s}$ and higher, and a single turbine type, T200, would be used at all sites with an annual average wind speed of $5.5 \mathrm{~m} / \mathrm{s}$ and lower. For sites with wind speeds between $5.5 \mathrm{~m} / \mathrm{s}$ and $10 \mathrm{~m} / \mathrm{s}$, a smoothly transitioned blend of the other three turbine types is used in the analysis. Figure 9 illustrates the proportion of turbine types for each wind speed.

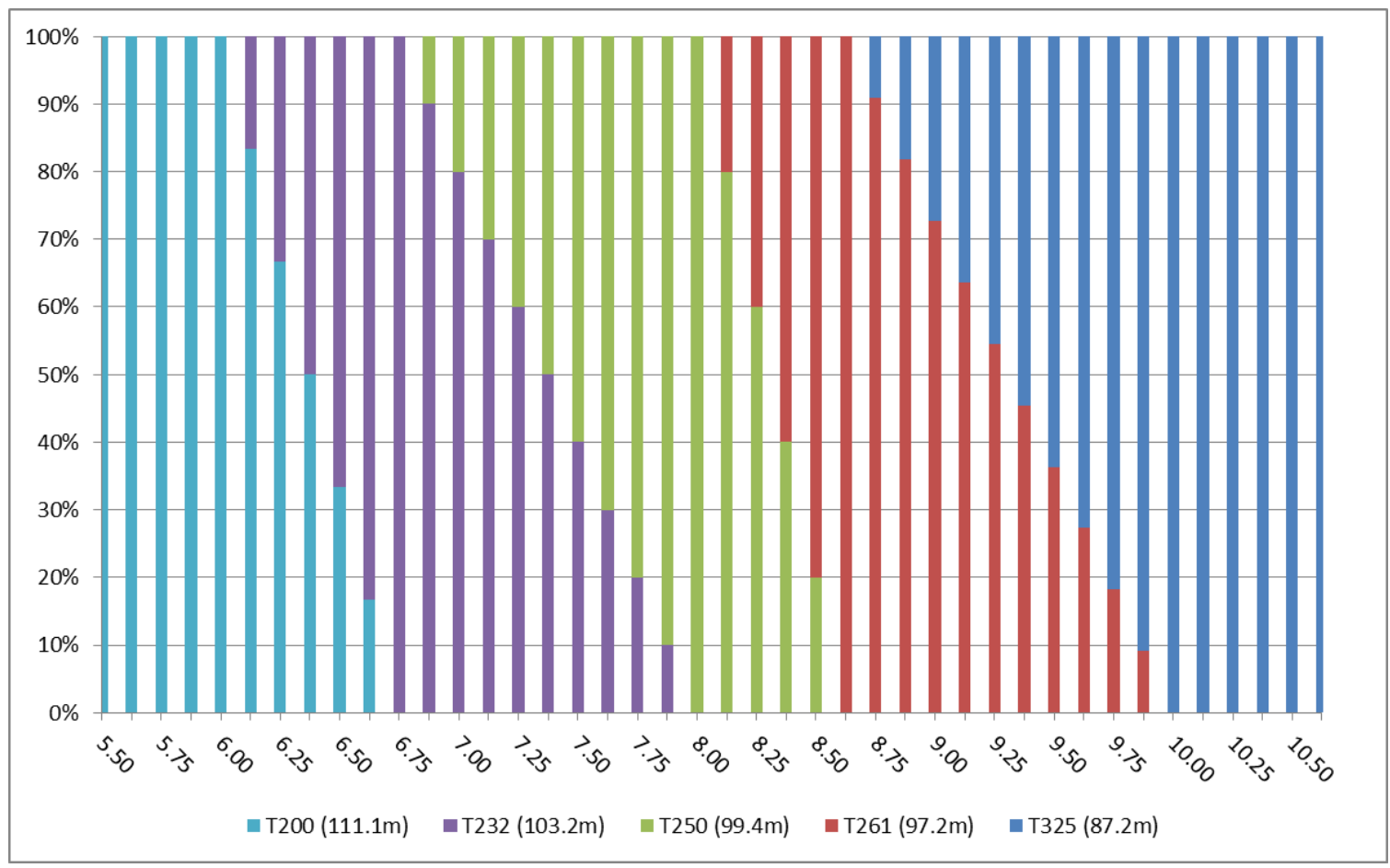

Figure 9. Wind turbine composition by wind speed

Source: NREL

\footnotetext{
${ }^{11}$ Regional variants associated with labor rates, material costs, and spur line costs to access existing infrastructure are not included in Table 13, but these effects are captured for each individual wind plant location in the supply curves.
} 
A unique CapEx value was calculated for each of the over 130,000 potential wind plant land areas. Based on the site annual average wind speed, the plant CapEx was interpolated between the two nearest representative wind turbines of the five defined in Table 13 A regional multiplier to account for effects such as labor rates and material costs was applied based on the geographic location of the site (Beamon and Leff 2013). In addition, a distance-based cost estimate for transmission infrastructure to connect the site to existing electrical infrastructure was included.

For each of the five representative wind plants, a wind turbine power curve was developed to estimate AEP (see Figure 10). Table 13 illustrates representative capacity factors that assume a Weibull-distributed wind regime with $\mathrm{K}=2.0$ for each wind plant power curve and annual average wind speed. To estimate AEP at the more than 130,000 areas for potential wind plant locations, AWS Truepower's long-term average hourly wind profiles were convolved with each of the power curves corresponding to the representative wind plants nearest the site's annual average wind speed. The AEP from each of the two wind plants was weighted by annual average wind speed to arrive at the site-specific estimated gross capacity factor. Estimated losses of $16.7 \%$, including availability, were applied to estimate the net capacity factor. Net capacity factor estimates below $20 \%$ were excluded from the supply curves, reducing the number of wind plant locations to $94,369 .{ }^{12}$

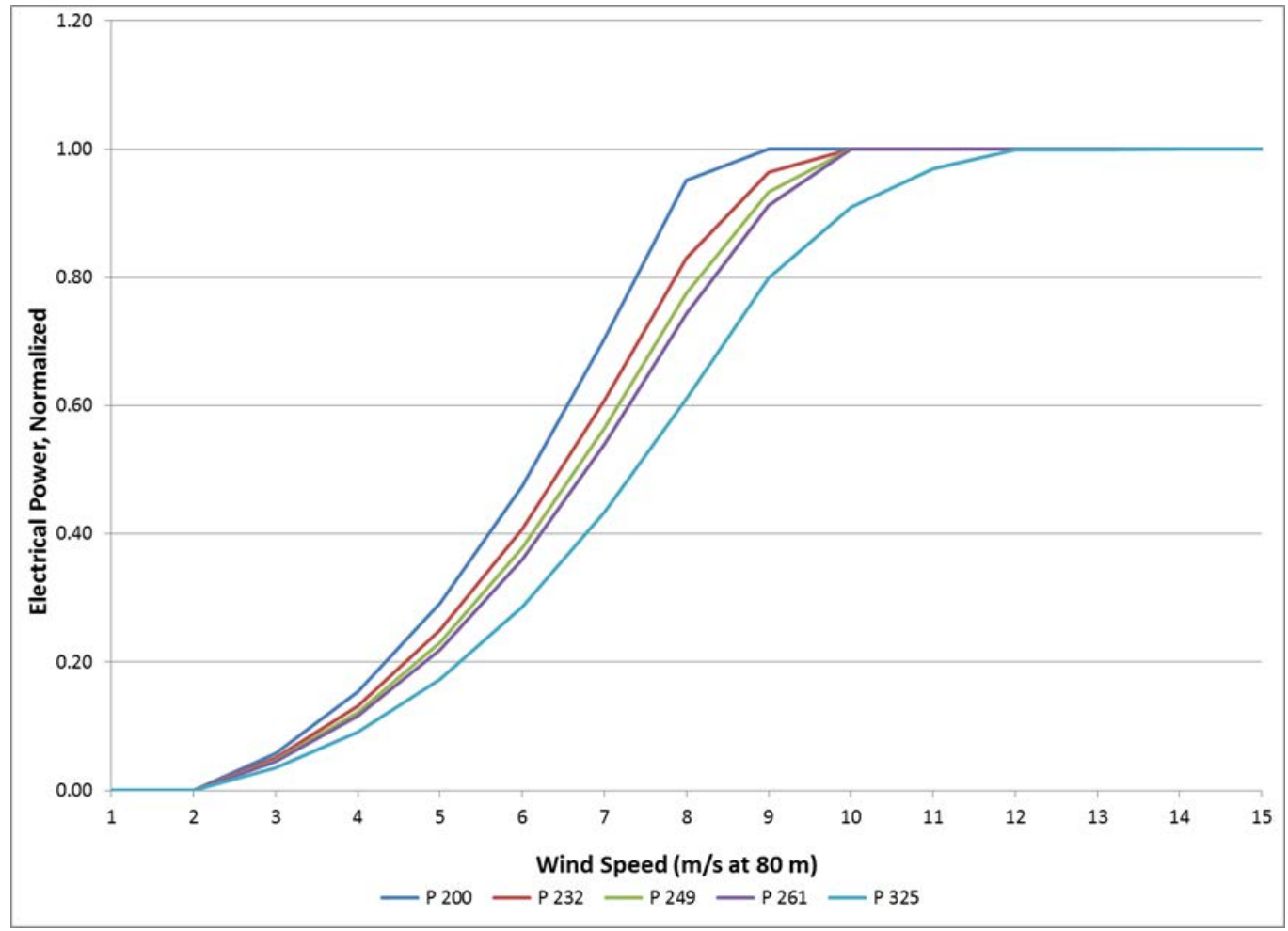

Figure 10. Power curves for five representative wind turbines

Source: NREL

\footnotetext{
${ }^{12}$ Eliminating locations where the estimated capacity factor was less than $20 \%$ eliminated sites in which LCOE values exceeded \$274/MWh. Future technology innovations toward lower specific power and higher hub heights could result in lower cost projects for the same geographic location. As a result, some of the locations with very high LCOE estimates based on 2014 wind technology characteristics could achieve lower costs with technology advances and be included in future supply curve representations.
} 


\subsubsection{U.S. Land-Based Wind Technology Supply Curves}

The LCOE for each of the potential wind plant locations was computed using the site-specific CapEx and AEP. A GIS-based algorithm that ranks sites within a region based on cost and allocates potential wind plant capacity to existing transmission line capacity, load centers, or a pool of resources to be accessed by new long-distance transmission infrastructure (DOE 2015b) provides a ranking of all potential wind plant locations (94,369 areas).

Figure 11 shows the estimated LCOE and estimated wind plant capacity for 94,369 potential wind plant locations in the contiguous United States. Assuming a wind plant density of $3 \mathrm{MW} / \mathrm{km}^{2}$, the contiguous United States possesses the theoretical potential for over 8,000 gigawatts (GW) of wind plants with LCOEs ranging from $\$ 42 / \mathrm{MWh}$ to $\$ 261 / \mathrm{MWh}$. The geographic locations in the wind resource supply that correspond to locations where 50 wind plants were installed in 2014 are shown as diamonds with LCOE values ranging from $\$ 52 / \mathrm{MWh}$ to $\$ 178 / \mathrm{MWh},{ }^{13}$ with a capacityweighted average of $\$ 65 / \mathrm{MWh}$.

Note that the LCOE values related to actual projects are estimates based on the assumptions discussed previously and do not reflect the specific costs associated with the installation of a given project. These estimates do, however, indicate that wind plants installed in 2014 represent a range of conditions that nearly spans the theoretical potential available for wind deployment.

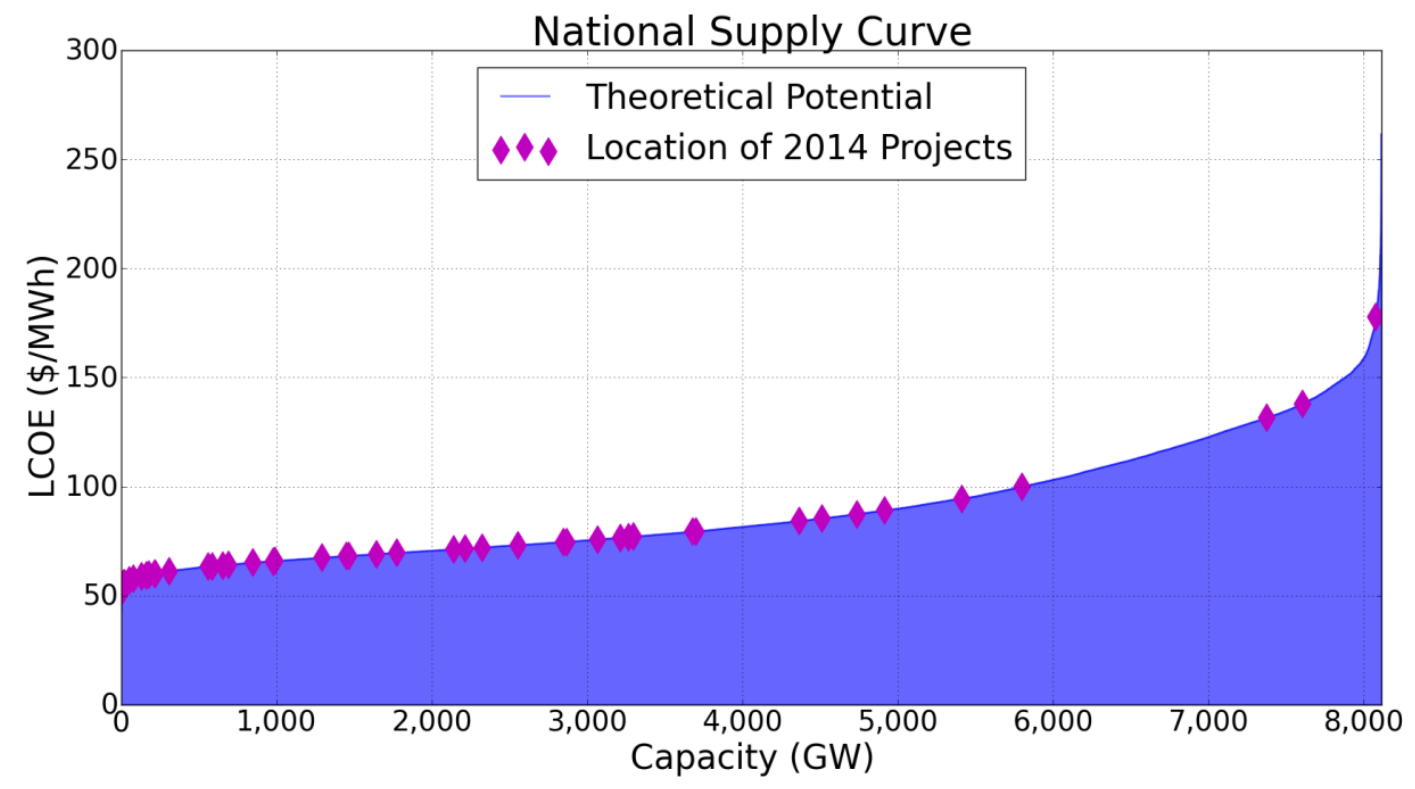

Figure 11. U.S. land-based wind resource supply curve with 2014 U.S. project locations

Source: NREL

The potential wind plant capacity available over a range of LCOEs varies by geographic region primarily because of the available wind resource characteristics. Incremental costs associated with labor rates, material costs, logistical or siting challenges, and distance to existing transmission

\footnotetext{
${ }^{13}$ In a few cases, the 2014 projects overlapped multiple wind resource areas; in these cases, the LCOE value for one of the resource areas is shown in Figure 11.
} 
infrastructure also contribute to regional differences. ${ }^{14}$ Supply curves illustrating the range of LCOE for the capacity available within each of five geographic regions is shown in Figures 12 through 16; the regions are defined and illustrated in Figure 2 (Section 4.1). Wind projects installed in 2014 in each of these geographic regions are highlighted using the corresponding geographic location's estimated LCOE value.

The majority of projects installed in 2014 are associated with the interior region of the country with LCOE estimates less than \$89/MWh (Figure 13). As expected, projects tend to be installed toward the left side of the resource supply curve where the costs are lowest, but projects are distributed across the range of resource potential; this is particularly evident in the interior and Northeast regions. Substantial low-cost resources remain available, though, in all regions of the country. The spread of projects across the range of resource potential available within a region suggests that wind plant locations are influenced by cost, but other considerations ultimately lead to a successful project. In other words, the lowest-cost resource within a region is not always utilized at the earliest stages of development.

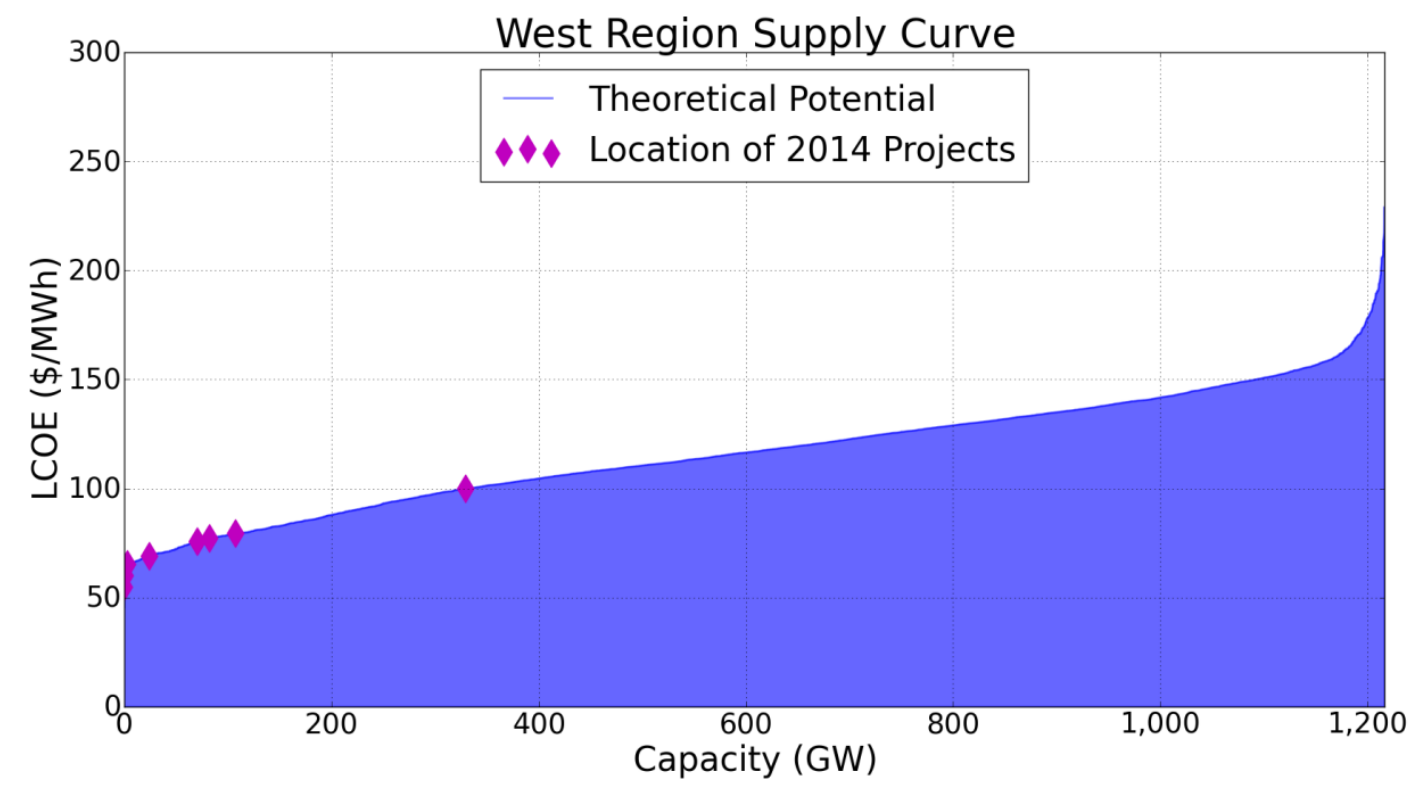

Figure 12. West region land-based wind supply curve with 2014 U.S. project locations Source: NREL

\footnotetext{
${ }^{14}$ Regional capital cost variations are represented based on Beamon and Leff (2013). Similarly to DOE (2015), an additional capital cost increment of $20 \%$ was applied to project locations in the Northeast region to reflect historical market-based capital costs for land-based wind projects, which have been observed to be higher in the Northeast compared to other regions.
} 


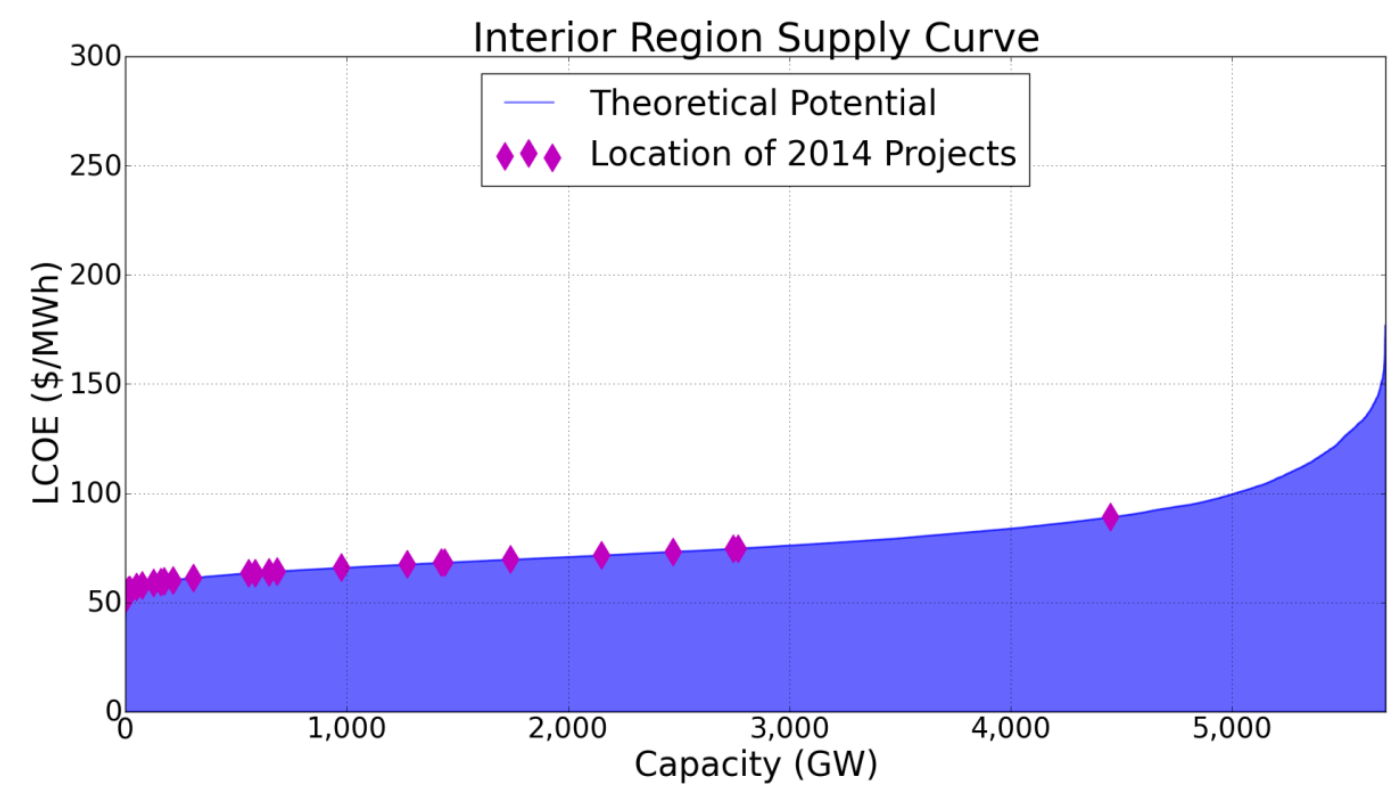

Figure 13. Interior region land-based wind supply curve with 2014 U.S. project locations Source: NREL

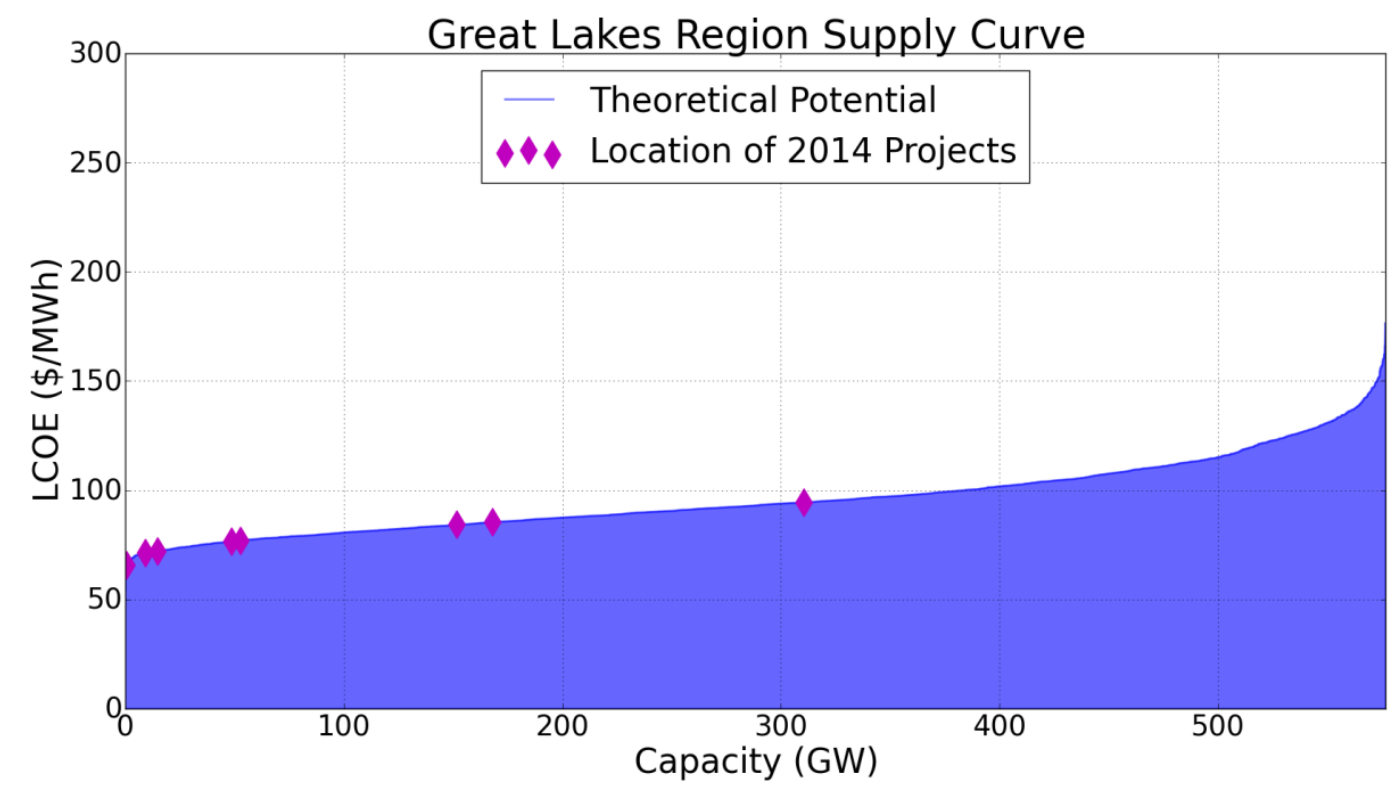

Figure 14. Great Lakes region land-based supply curve with 2014 U.S. project locations Source: NREL 


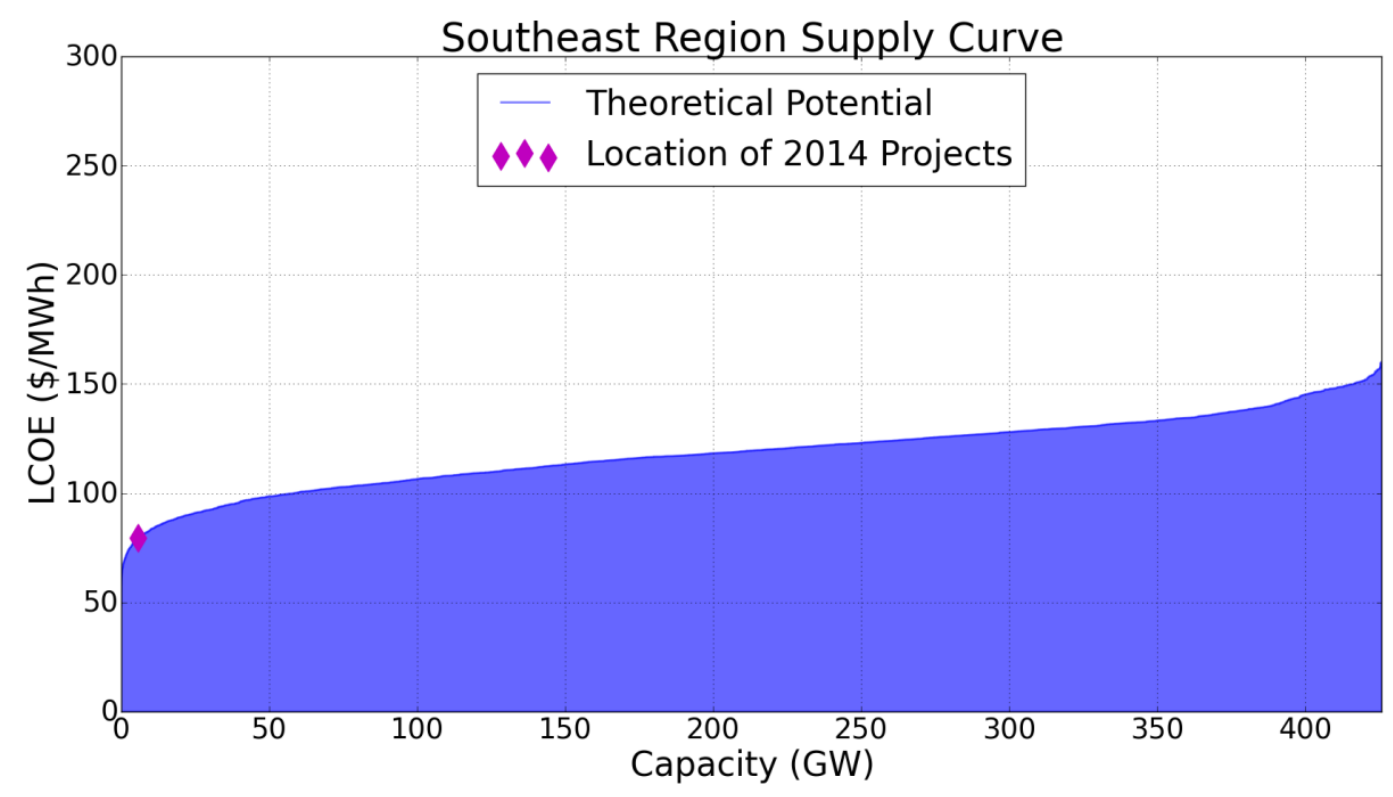

Figure 15. Southeast region land-based supply curve with 2014 U.S. project locations Source: NREL

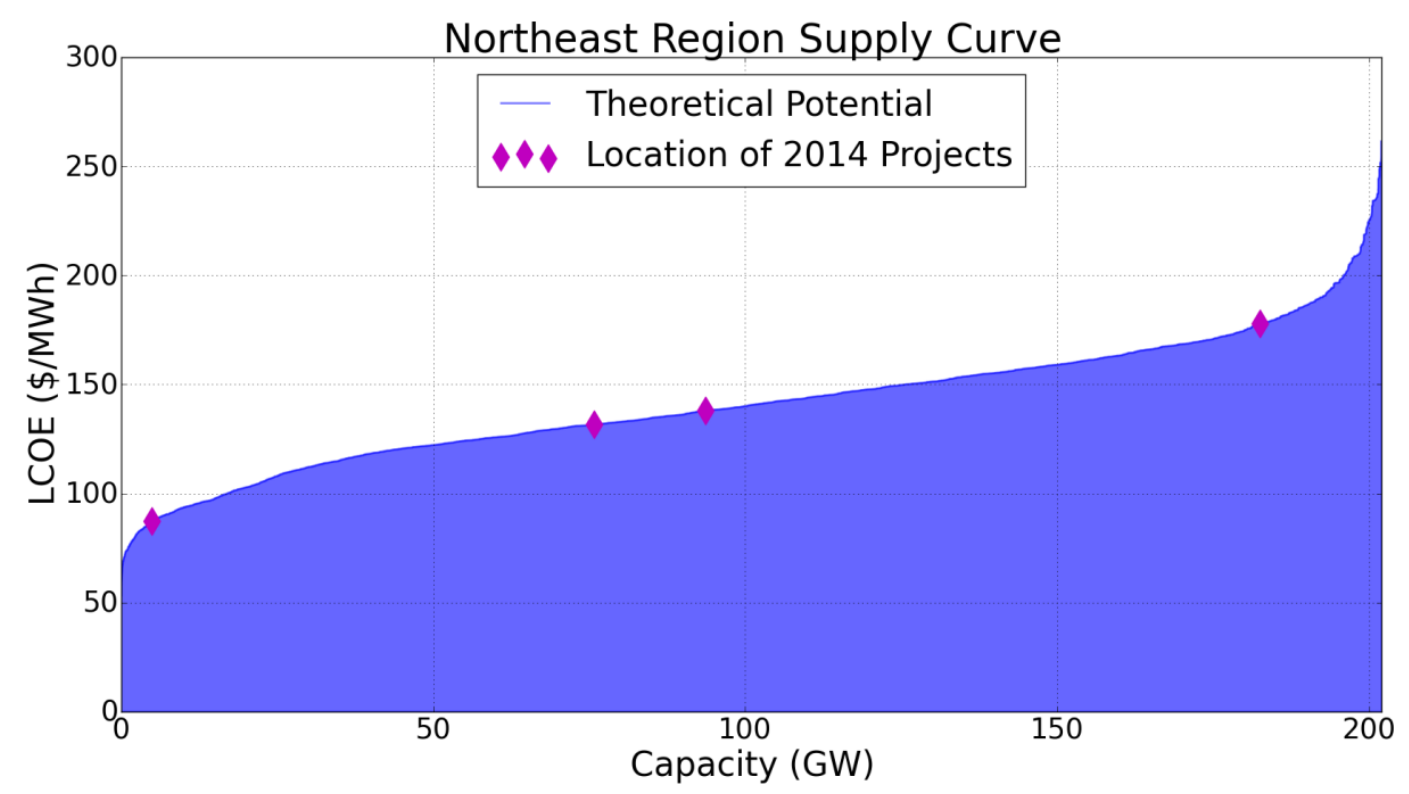

Figure 16. Northeast region land-based supply curve with 2014 U.S. project locations Source: NREL

The LCOE estimates shown in the figures do not reflect potential revenue streams including PPAs or PTCs, which are mechanisms commonly used by wind plant owners to recoup costs. Hand et al. (2015) demonstrated that combinations of reported PPA prices and typical policy mechanisms such as the PTC are often adequate to offset LCOE estimates of wind plants in the United States. 
Combined-cycle natural gas plants are frequently the primary technology that competes against new wind plant investments. Lazard (2014) and BNEF (2015) have estimated LCOE for new combined-cycle gas turbine plants in the United States at \$61-\$87/MWh and \$44-\$51/MWh, respectively. In each case, different assumptions are used to reflect the range of CapEx, OpEx, capacity factor, and project finance, so comparison with the wind LCOE estimates in this report cannot be made directly. The wind LCOE estimates illustrate, however, that there are locations in the United States that are within or below these combined-cycle gas turbine estimates, particularly in the interior region of the country. For example, in the interior region, 1,856 GW of capacity has LCOE estimates less than $\$ 70 / \mathrm{MWh}$. Similarly, $31 \mathrm{GW}$ in the West, $5 \mathrm{GW}$ in the Great Lakes, 1 GW in the Southeast, and $0.4 \mathrm{GW}$ in the Northeast regions have estimated LCOE below \$70/MWh.

The national and regional supply curves shown in Figures 11 through 16 illustrate that there is a significant range of LCOE across the country when wind turbine technology is matched with wind resource conditions and other geographic factors that affect the COE estimate. LCOE estimates at geographic locations that correspond with locations where projects were installed in 2014 also demonstrate a broad range of LCOE. In general, projects are associated with locations at the lower end of the range, but in many regions, projects were installed in 2014 at locations that are associated with higher LCOEs. This suggests that factors beyond least cost drive wind project realization. In all regions of the United States there are locations with estimated LCOE values that are within or below LCOE estimates for combined-cycle gas plants, indicating that a large amount of cost-effective wind resource remains available for development. 


\section{Offshore Wind}

Although no offshore wind projects have been installed in the United States to date, the first project began offshore construction in April 2015 and is scheduled to begin operation in the fall of 2016. The lack of domestic experience with offshore wind technology introduces considerable uncertainty into cost estimates for potential domestic offshore wind projects. The market data for this report are provided in the 2014-2015 U.S. Offshore Wind Technologies Market Report (Smith et al. 2015). This report provides an analysis of offshore wind cost trends in Europe as well as projections for the United States. It updates the previous offshore market research conducted by Navigant Consulting, Inc. (Hamilton et al. 2014) as well as the reported costs of domestic offshore wind energy reported in the 2013 Cost of Wind Energy Review (Moné et al. 2015) by drawing on global fixed-bottom offshore wind market data, utilizing past offshore wind economic analyses and running NREL's suite of cost and performance models.

For this report, the fixed-bottom offshore wind reference project was derived from representative characteristics of 2014 wind projects consisting of $1473.39-\mathrm{MW}$ turbines (500 MW of total installed capacity) with a $115.4-\mathrm{m}$ rotor diameter on an $85.8-\mathrm{m}$ tower. The capacity-weighted average of 2014 CapEx $^{15}$ costs was calculated to be $\$ 5,925 / \mathrm{kW}$, with total pretax OpEx reported at $\$ 138 / \mathrm{kW} / \mathrm{yr}$. Accordingly, these values were ascribed to the offshore reference project. Given these inputs, as well as the additional variables considered to reflect the reference project and summarized in Table 14, the resulting LCOE is $\$ 193 / \mathrm{MWh}$. Although information on floating offshore wind projects is not included here, it is planned to be covered in future iterations of this report.

Table 14. Summary of Inputs and Results for the Fixed-Bottom Offshore Wind Project

\begin{tabular}{|c|c|c|c|}
\hline $\begin{array}{l}\text { Data } \\
\text { Source }^{a}\end{array}$ & & $\begin{array}{l}\text { 3.39-MW Offshore } \\
\text { Turbine (\$/kW) }\end{array}$ & $\begin{array}{c}\text { 3.39-MW Offshore } \\
\text { Turbine (\$/MWh) }\end{array}$ \\
\hline Model & Turbine capital cost & 1,952 & 51 \\
\hline Model & BOS costs & 2,277 & 60 \\
\hline Model & Financial costs & 1,084 & 29 \\
\hline Model & Market price adjustment & 612 & 16 \\
\hline Market & CapEx & 5,925 & 156 \\
\hline Market & OpEx (\$/kW/yr) & 138 & 37 \\
\hline Market & FCR $(\%)$ & \multicolumn{2}{|c|}{$9.8 \%$} \\
\hline Model & $A E P_{\text {net }}(\mathrm{MWh} / \mathrm{MW} / \mathrm{yr})$ & \multicolumn{2}{|c|}{3,716} \\
\hline Model & Capacity factor (\%) & \multicolumn{2}{|c|}{42.4} \\
\hline Calculated & TOTAL LCOE (\$/MWh) & \multicolumn{2}{|c|}{193} \\
\hline
\end{tabular}

${ }^{a}$ Sources are listed in the relevant sections of this report related to the specific cost components.

Note: Reported costs are in 2014 U.S. dollars using U.S. CPI data.

\footnotetext{
${ }^{15}$ CapEx costs represent the cost of building a plant and do not include financing or escalation costs, which can vary with risk perception, construction schedules, inflation expectations, and other factors.
} 


\subsection{Market Developments in 2014}

The cumulative global offshore wind market reached approximately $8.1 \mathrm{GW}$ by the end of 2014 , with an expected total of $12.2 \mathrm{GW}$ by the end of 2015 (Smith et al. 2015). To date, offshore wind development has been highly concentrated geographically, with over $95 \%$ of cumulative capacity commissioned in Europe. Specifically, 51\% is located in the United Kingdom as of June 30, 2015. Commissioned projects in Asia are starting to accelerate, with $310 \mathrm{MW}$ commissioned in China and $52 \mathrm{MW}$ in Japan. Analysis of the global markets suggests that they are poised for growth with aggressive goals in both Europe and Asia; however, deployments have been affected by uncertainty in the form, and value of, incentives (United Kingdom); delays in grid development (Germany); and local and national government concerns (China). In the United States, the three principal hurdles are:

- An uncertain timeline for permitting. The Bureau of Ocean Energy Management (BOEM) [2011]) has made considerable progress in leasing and permitting projects since the "Smart from the Start" initiative was announced in 2010. BOEM has awarded commercial leases in three wind energy areas and is moving forward with an additional four, as well as two unsolicited lease request areas. Despite this progress, the total timeline for permitting remains to be seen.

- The scheduled expiration of federal tax credit incentives. The PTC and ITC, the principal federal incentives for wind energy generation, expired at the end of 2013. ${ }^{16}$ Uncertainty over the availability of these incentive programs creates significant market risk and makes investors hesitant to commit capital for essential activities in the development phase. Furthermore, this uncertainty is likely to slow the development of the offshore wind industry because the multiyear development horizons for projects tend to exceed the typical periods when the PTC/ITC are available for wind. In July 2015, Senators Tom Carper (Delaware) and Susan Collins (Maine) reintroduced the Incentivizing Offshore Wind Power Act (S. 1736), which would provide a 30\% ITC for the first $3 \mathrm{GW}$ of U.S. offshore wind projects. The ITCs would be awarded through an application process jointly managed by DOE and the U.S. Department of the Interior, and successful projects will have 5 years from the date of issuance to commission the project.

- The lack of a defined market for offshore wind power. The biggest near-term challenge for the offshore wind energy industry is the lack of a defined market. Federal incentives are generally not sufficient to attract investment in offshore wind projects by themselves given the current cost structure, and there is significant ambiguity about the continued availability of these incentives. Developers are therefore working through state representatives to augment the federal incentives and achieve financial viability, either through offshore wind-specific revenue streams (Offshore Renewable Energy Credits) or by negotiating long-term PPAs. Although this approach is allowing a number of projects to move forward, it is very complicated and resource-intensive for developers.

\footnotetext{
${ }^{16}$ Two offshore wind projects started construction before the expiration of the tax credits- the 468-MW Cape Wind project and the 30-MW Block Island Wind Farm. Both have announced that they have met the "safe harbor" criteria defined by the U.S. Internal Revenue Service and expect to qualify for the investment tax credit (Broehl and Ernst 2014).
} 


\subsection{CapEx for Fixed-Bottom Offshore Wind Reference Project}

The offshore project CapEx was estimated by utilizing NREL's newly developed OWDB, which contains information on 1,382 offshore wind projects. The data were obtained by conducting several parallel assessments: analyzing global market data, reviewing published literature, and interviewing active offshore wind developers in the United States. This multipronged approach yielded a WACC of $\$ 5,925 / \mathrm{kW}$ in 2014 across the industry for fully operational projects worldwide. Figure 17 shows the variation of reported CapEx over time for global offshore wind projects that are installed, under construction, contracted, approved, in permitting, and in planning.

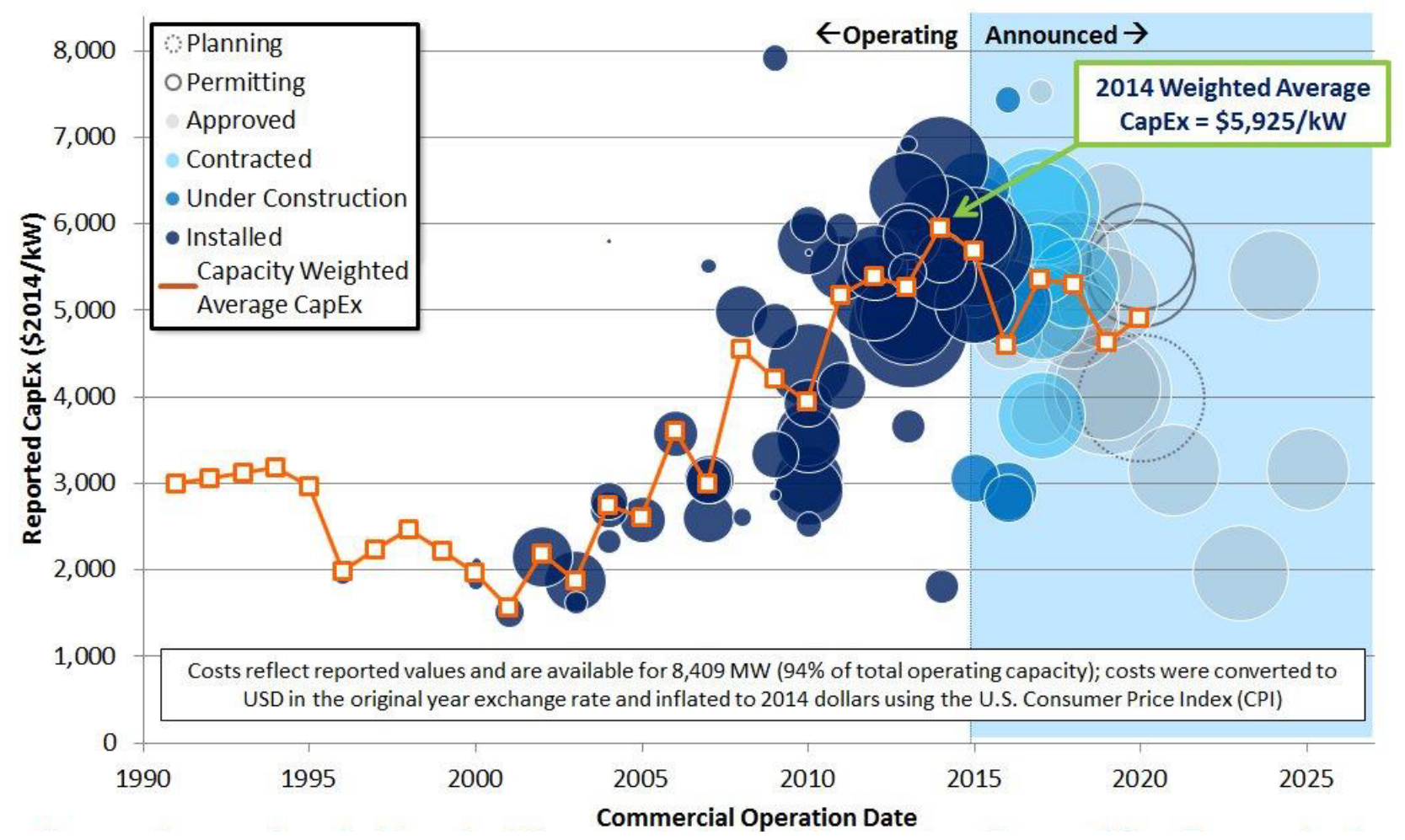

Figure 17. Reported capital costs for offshore wind projects in $\mathbf{\$ 2 0 1 4}$ (includes full record from 1990)

Source: NREL

The costs were converted to U.S. dollars (USD) in the original reported year exchange rate and inflated to 2014 USD using the CPI. The CapEx significantly rose between 2005 and 2014; however, projections suggest that CapEx may be stabilizing or even declining beyond 2014. Individual CapEx data points should be viewed with a degree of skepticism because: 1) they are normally self-reported by developers and difficult to verify independently, 2) there is limited transparency into the financial impact of cost overruns, and 3) it is often unclear whether the reported CapEx is comprehensive and fully captures the cost to install the project and connect it to the grid. ${ }^{17}$ When viewed together, though, these data provide insight into long-term cost trends. Changes in the cost structure during this period were driven by a number of factors, including: ${ }^{18}$

\footnotetext{
${ }^{17}$ For example, it is unclear if the announced CapEx values include soft costs such as construction financing, insurance, or fees.

${ }^{18}$ For a full discussion, see UK Energy Research Center (2010), Deloitte (2011), and Greenacre et al. (2010).
} 
- Increasing technical challenges of installing turbines in deeper water, farther from shore, and in more challenging meteorological ocean conditions (e.g., wind speeds, wave heights, and currents), which pose challenges for both technical design and construction

- Shortages in the supply chain (e.g., components, vessels, and skilled labor)

- Increasing prices for commodities and energy

- Macroeconomic trends including movements in exchange rates, commodity prices, and energy prices

- An improved appreciation of the costs and risk associated with offshore wind project implementation, leading to more conservative pricing strategies from equipment suppliers and installation contractors (Smith et al. 2015).

The global offshore market data were also used to estimate the offshore reference turbine capital cost. The BOS and financial estimates were calculated using NREL's Offshore Balance of System Model with input from market data. For the fixed-bottom offshore wind reference project, the BOS and financial cost results from the NREL model are augmented to reflect the current market cost data (for the turbine capital cost and project CapEx) by using a market price adjustment. The need for a market price adjustment is primarily attributed to the different spatial characteristics between the fixed-bottom offshore reference project and the global offshore market data. Using global offshore wind projects to estimate CapEx introduces a mismatch of spatial characteristics such as water depth and distance to shore that do not represent the U.S. offshore reference project. In other words, the global average water depth in 2014 was approximately $19 \mathrm{~m}$ and the distance from shore was about $30 \mathrm{~km}$ as compared to the fixed-bottom offshore reference project's $15-\mathrm{m}$ water depth and 20-km distance from shore. Figure 18 compares the capacity-weighted average depth and distance from shore in 2013 and 2014 compared to the offshore reference site. 


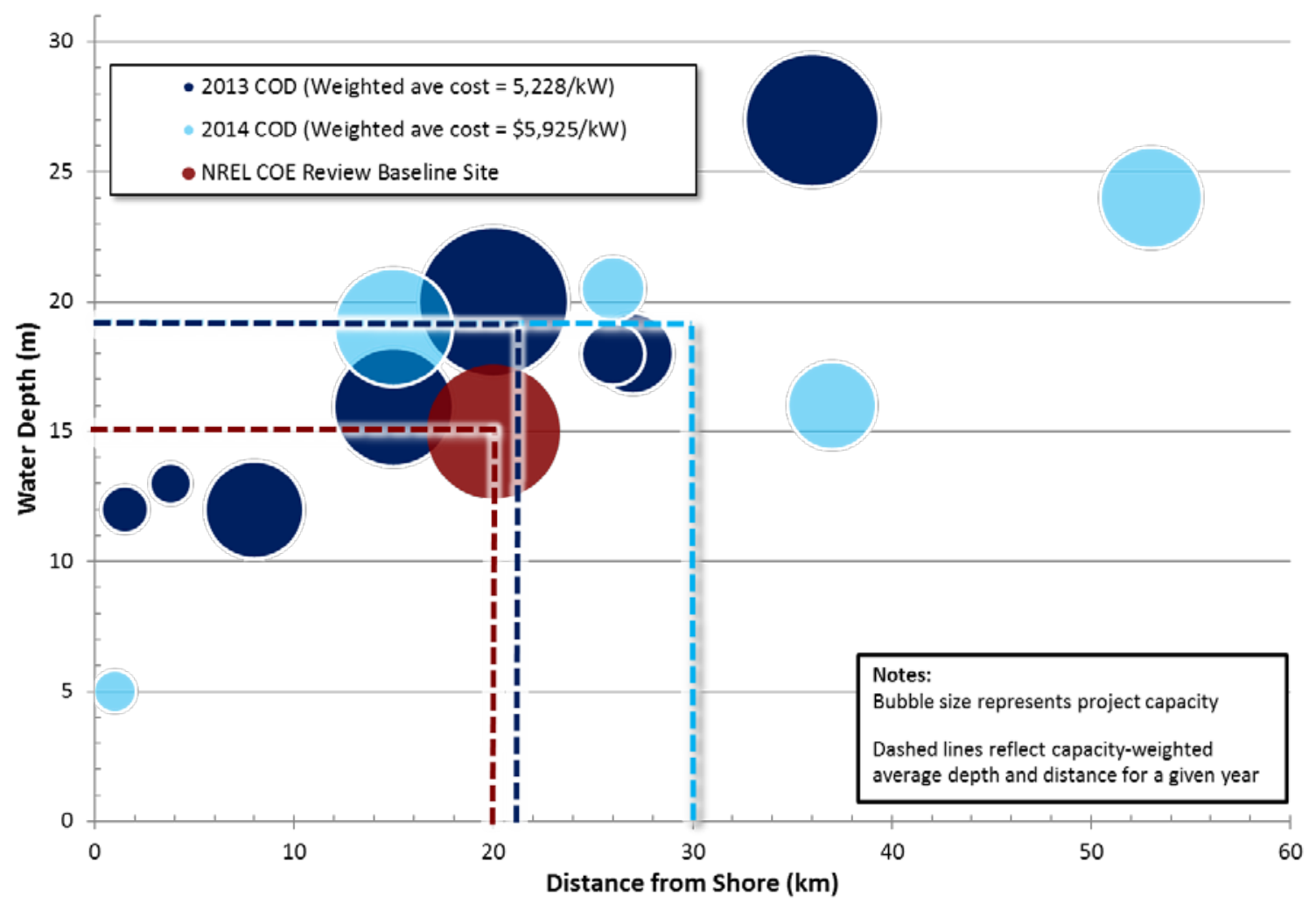

Figure 18. Comparison of water depth and distance from shore of the offshore reference site and the average global market data

Source: NREL

After running the NREL Offshore BOS Model to reflect the global offshore average water depth and distance from shore, the cost increase for BOS results in the market price adjustment being reduced $46 \%$, from $\$ 612 / \mathrm{kW}$ to $\$ 331 / \mathrm{kW}$. This reduction of market price adjustment is a result of modeling with spatial parameters that more closely represent the spatial parameters of the global offshore market data. The average water depth, distance from shore, and market price adjustment for the global market data and the offshore reference project are summarized in Table 15.

Table 15. Comparison of Effects of Fixed-Bottom Offshore Reference Wind Project to Global Market Data on Market Price Adjustment

\begin{tabular}{|l|c|c|c|}
\hline \multicolumn{1}{|c|}{$\begin{array}{c}\text { Fixed-Bottom } \\
\text { U.S. Offshore } \\
\text { Reference Project }\end{array}$} & $\begin{array}{c}\text { Average } \\
\text { Global Market } \\
\text { Data }\end{array}$ & $\begin{array}{c}\text { Percent } \\
\text { Change } \\
(\%)\end{array}$ \\
\hline Water depth $(\mathrm{m})$ & 15 & 19 & $(+) 27$ \\
\hline Distance from shore $(\mathrm{km})$ & 20 & 30 & $(+) 50$ \\
\hline Market price adjustment $(\$ / \mathrm{kW})$ & 612 & 331 & $(-) 46$ \\
\hline
\end{tabular}

Source: NREL OWDB 
A breakdown of the CapEx for the fixed-bottom offshore reference project, according to the offshore wind cost breakdown structure, including the addition of the market price adjustment, is shown in Figure 19. Percentage estimates for turbine capital cost and total CapEx were based on market data. BOS capital costs and financial capital costs were estimated using NREL's Offshore BOS Model. The market price adjustment percentage is the difference between the global market CapEx $(\$ 5,925)$ and the modeled CapEx outputs. The segment in green represents the turbine cost, shades of blue represent BOS costs, shades of purple represent financial costs, and gray is the market price adjustment cost. The dollar-value component cost breakdown is shown in Table 16 .

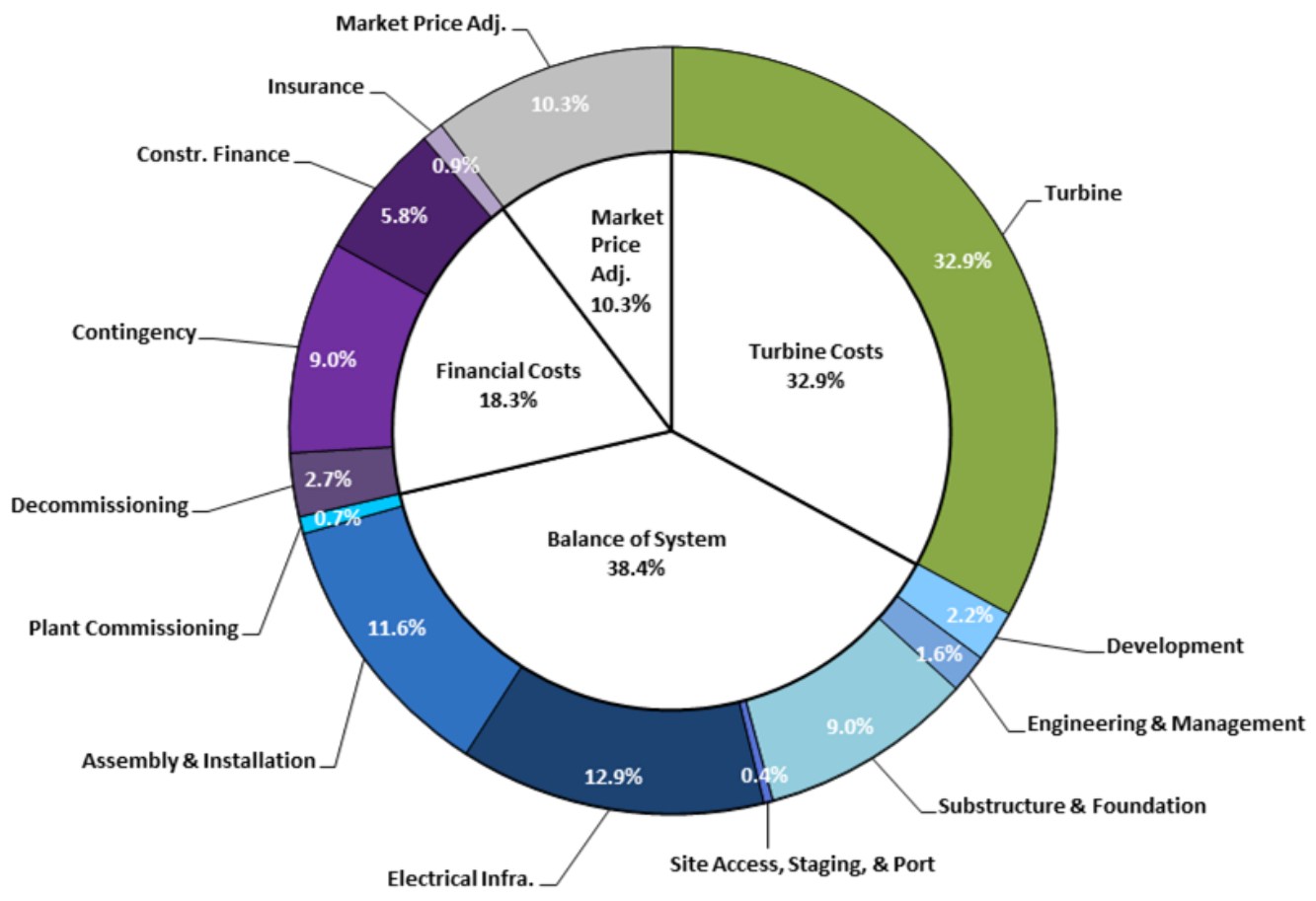

Figure 19. Capital expenditures for the 2014 offshore wind reference project

Source: NREL 
Table 16. Fixed-Bottom Offshore LCOE Component Cost Breakdown

\begin{tabular}{|c|c|c|}
\hline & $\begin{array}{c}\text { 3.39-MW } \\
\text { Offshore Turbine } \\
\text { (\$/kW) }\end{array}$ & $\begin{array}{c}\text { 3.39-MW Offshore } \\
\text { Turbine } \\
\text { (\$/MWh) }\end{array}$ \\
\hline TURBINE CAPITAL COST & 1,952 & 43 \\
\hline Development Cost & 129 & 3 \\
\hline Engineering Management & 97 & 2 \\
\hline Substructure and Foundation & 535 & 12 \\
\hline Site Access, Staging, and Port & 23 & 1 \\
\hline Electrical Infrastructure & 763 & 17 \\
\hline Assembly and Installation & 687 & 15 \\
\hline Plant Commissioning & 43 & 1 \\
\hline BALANCE OF SYSTEM & 2,277 & 50 \\
\hline Insurance & 53 & 1 \\
\hline Decommissioning (Surety Bond) & 159 & 3 \\
\hline Construction Financing Cost & 341 & 7 \\
\hline Contingency & 531 & 12 \\
\hline FINANCIAL COSTS & 1,084 & 23 \\
\hline MARKET PRICE ADJUSTMENT & 612 & 13 \\
\hline TOTAL CAPITAL EXPENDITURES & 5,925 & 129 \\
\hline
\end{tabular}

There is a notable difference between the cost components that make up the land-based and offshore projects. In the land-based project, $71 \%$ of the cost is related to the turbine. For the offshore project, the turbine makes up 33\% of the CapEx.

\subsection{Operating Expenditures for Offshore Wind}

There has been no indication that expected OpEx for offshore wind projects have shifted between 2010 and 2014. The OpEx baseline for 2014 was assumed to be $\$ 37 / \mathrm{MWh}$, equivalent to $\$ 138 / \mathrm{kW} / \mathrm{yr}$, with a range extending from $\$ 20 / \mathrm{MWh}$ to $\$ 70 / \mathrm{MWh}$. The equivalent range on a dollars-per-kilowatt-per-year basis extends from $\$ 68 / \mathrm{kW} / \mathrm{yr}$ to $\$ 239 / \mathrm{kW} / \mathrm{yr}$. Operating costs are broken down into MAIN and OPER costs. ${ }^{19}$ One of the cost categories that make up OPER cost is the Outer Continental Shelf lease payment, ${ }^{20}$ which is estimated to be $12 \%$ of the OPER cost. The increase from the 2013 Cost of Wind Energy Review (Moné et al. 2015) of $\$ 136 / \mathrm{kW} / \mathrm{yr}$ to the

\footnotetext{
${ }^{19} \mathrm{O} \& \mathrm{M}$ costs for offshore wind projects are assumed to include labor, vessels, equipment, scheduled maintenance, unscheduled maintenance, land-based support, and project administration.

${ }^{20}$ Lease payments are expected to range between $2 \%$ and $7 \%$ of operational revenue. Cape Wind will pay $2 \%$ of operational revenue in years 1 to 15 . The lease payment increases to $7 \%$ of operational revenue from year 16 until the plant is decommissioned (BOEM 2011).
} 
$\$ 138 / \mathrm{kW} / \mathrm{yr}$ in this report is solely a result of applying a $2 \%$ inflation rate. Additional details can be found in Wind Vision (DOE 2015b).

\subsection{Offshore Annual Energy Production and Capacity Factor}

Smith et al. (2015) reported that installed European offshore wind projects typically achieve capacity factors between $30 \%$ and 55\%. In general, capacity factors are improving for two reasons. First, siting decisions for initial projects emphasized locations that were close to shore and somewhat sheltered so that developers could gain experience before moving into open-ocean conditions. Offshore wind development zones are now increasingly located farther from shore to allow for larger projects and enable access to a more energetic and consistent wind resource. Second, offshore wind turbine technology has improved over the last decade; larger rotor-togenerator ratios increase the amount of energy that can be captured in a given wind resource and taller hub heights allow turbines to access higher wind speeds as a result of the wind shear.

Because $\mathrm{AEP}_{\text {net }}$ and the corresponding net capacity factor will vary with the wind resource and project design, the authors assumed specific site characteristics that are common to the North Atlantic Coast for the reference offshore wind project. $\mathrm{AEP}_{\text {net }}$ was calculated using commercially available technology and NREL's wind turbine design Cost and Scaling Model with typical wind resources of the North Atlantic. Turbine characteristics, such as turbine rated power, rotor diameter, and hub height were assumed from the weighted average values of the global offshore wind data. Table 17 shows the assumptions used to calculate the $\mathrm{AEP}_{\text {net }}$ for the reference project.

Table 17. Fixed-Bottom Reference Offshore AEP Input Assumptions

\begin{tabular}{|lc|}
\hline \multicolumn{2}{|c|}{ Turbine Parameters } \\
\hline Turbine rated power $(\mathrm{MW})$ & 3.39 \\
\hline Turbine rotor diameter $(\mathrm{m})$ & 115.4 \\
\hline Turbine hub height $(\mathrm{m})$ & 85.8 \\
\hline Maximum rotor tip speed $(\mathrm{m} / \mathrm{s})$ & 90 \\
\hline Tip-speed ratio at peak coefficient of power $\left(\mathrm{C}_{\mathrm{p}}\right)$ & 8 \\
\hline Drivetrain design & Geared \\
\hline Rotor peak power coefficient $\mathrm{C}_{\mathrm{p}}$ & 0.47 \\
\hline & \\
\hline Annual average wind speed at $50 \mathrm{~m}(\mathrm{~m} / \mathrm{s})$ & 8.4 \\
\hline Annual average wind speed at $85.8 \mathrm{~m}(\mathrm{~m} / \mathrm{s})$ & 8.87 \\
\hline Weibull K & 2.1 \\
\hline Shear exponent & 0.1 \\
\hline & \\
\hline Losses (array, energy conversion, line) & $15 \%$ \\
\hline Availability & $96 \%$ \\
\hline
\end{tabular}


As with typical offshore wind plants in Europe, the offshore reference project will experience losses from array wake impacts, availability, and inefficiencies in power collection and transmission. Total system losses were assumed to be $19 \%$ and were used to calculate AEP ${ }_{\text {net }}$. Table 18 shows the impact of losses on $\mathrm{AEP}_{\text {net }}$ and capacity factor.

Table 18. Offshore Wind Turbine AEP and Capacity Factor Summary

\begin{tabular}{|lc|}
\hline Gross AEP (MWh/MW/yr) & $\begin{array}{c}\text { 3.MW Offshore } \\
\text { Turbine }\end{array}$ \\
\hline Gross capacity factor (\%) & 4,554 \\
\hline Losses and availability (\%) & 52.0 \\
\hline AEP $_{\text {net }}(\mathrm{MWh} / \mathrm{MW} / \mathrm{yr})$ & 19 \\
\hline Net capacity factor (\%) & 3,716 \\
\hline
\end{tabular}

The 2014 baseline project will deliver 3,716 MWh/MW of installed capacity annually, which is equivalent to a net capacity factor of $42.4 \%$. The range of $\mathrm{AEP}_{\text {net }}$ estimates around this baseline extends from 1,578 to 3,988 MWh/MW/year, which corresponds to the range of capacity factors $(30 \%-55 \%)$ observed in Europe.

\subsection{Financial Parameters for Offshore Wind}

The modern expression of offshore wind was born in Denmark in 1991, and although the United States is a leader in cumulative installed wind energy production, the first domestic commercial offshore wind project has yet to become operational. After successfully securing financing in March 2015, the Block Island Wind Farm has begun offshore construction and is anticipated to begin operation in late 2016.

Investors and lenders recognize the risks that abound in capital-intensive offshore wind projects, and particularly in the U.S. offshore wind sector (Remec et al. 2013). As one prominent example of offshore wind development, Cape Wind began development in 2001, but has faced obstacles for many years. In January 2015, the utilities slated to purchase power from Cape Wind terminated their PPAs with the project because of Cape Wind's inability to meet a key milestone to obtain full project financing and start construction, or alternatively, to post financial collateral to extend the agreements (O’Sullivan 2015).

Given the small number of planned domestic offshore wind projects and a somewhat stagnant market that is waiting on tax policy clarification, characterizing offshore wind financing from both domestic and European offshore experience is required. U.S. projects will benefit from European experience until a few U.S. projects are fully financed, built, and begin operating, providing clarity about the risks in the domestic offshore wind business.

\subsubsection{Overview of European Trends in Offshore Wind Finance}

The European Union power sector continues to move away from oil, coal, and natural gas fuel sources. Nearly $12 \mathrm{GW}$ of total wind power capacity (8.1 GW of offshore) was installed in the European Union during 2014, attracting both investors and lenders to the sector (European Wind 
Energy Association [EWEA] 2015a). Historically, power producers in Europe have used their balance sheets to finance offshore wind projects, but with increasing demand for capital, other investors are entering the market, including wind turbine manufacturers, corporate investors, oil and gas companies, and EPC companies (EWEA 2013). Analysts expect compounded annual growth in the European offshore wind market to exceed 20\% from 2014 through 2020. Such growth will require project financing, along with selling shares of projects to free up capital for future development (BNEF 2014).

BNEF's list of completed offshore wind financial transactions for the period January 2012 through May 2015 includes 96 projects outside of the Americas (Table 19; BNEF 2015).

Table 19. Location of Offshore Projects, 2012-2015

\begin{tabular}{|lc|}
\hline Geographic Location & Number of Projects \\
\hline Asia (Japan, China, Korea) & 24 \\
\hline United Kingdom (UK) & 37 \\
\hline Europe (except UK) & 35 \\
\hline
\end{tabular}

The transaction types include mostly new construction and operating project acquisition with some refinancing. More than $75 \%$ were balance sheet transactions, and nearly all the remaining projects were term-loan financed, with projects in the United Kingdom making up half of the term-loan financed projects. Across the entire group of projects listed with both project cost and debt, debt comprises approximately $70 \%$ of total project cost.

Projects connected to the grid in 2014 included 141 MW in Belgium, 528.9 MW in Germany, and 813.4 MW in the United Kingdom (EWEA 2015b). New gross capacity of 2,323 MW were likely committed and financed between late 2012 and early 2014, of which 954 MW was financed on a stated nonrecourse basis. A blend of information that includes wind projects commissioned in 2014, as well as wind energy financing transaction fundamentals in 2014 for the representative wind project, is used in this report. Pricing for offshore wind in Europe is stated as between 250 and 350 bps above LIBOR (20 to 50 bps premium above land-based wind projects), and with interest rates hedging over the full loan amortization period, all-in market interest rates appear to range from $4.0 \%$ to $5.0 \%$ (Freshfields 2014 ).

From a European trend perspective, analysts anticipate that the shift toward more debt financing will continue as lenders gain experience with the sector and as utilities and sponsors require more capital. More than a dozen large-project finance banks are active in the space, investing as a club and syndicating further to smaller banks entering the arena. Historically, strong public policy and pricing support along with multilateral lending supported the growth of offshore wind in Europe, but debt investors are becoming more comfortable as the offshore industry becomes more mature. The recently financed Nordsee One was fully funded within 6 months with the debt offering oversubscribed and absent any multilateral participation (Guillet 2015). Available data suggest that activity in the equity space includes investment/acquisition of all or a portion of projects, as well as divestment of equity stakes in whole or in part (Freshfields 2014). Equity yields in the 
European Union can range depending on the investor type, leverage, and incentives, and are typically in the range between $11 \%$ and $15 \%$.

\subsubsection{Overview of U.S. Trends in Offshore Wind Finance}

After experiencing some challenges and setbacks, the first U.S. offshore wind project closed financing and began offshore construction in 2015. The following events of 2014 and early 2015 have advanced the sector significantly:

- The successful final permitting in 2014 of Deepwater Wind's Block Island Wind Farm, and ultimate financing and construction commencement in early 2015 set a new record for U.S. offshore wind. The \$360-million project (which is the combination of project costs, reserve accounts, and financial costs) was financed with a more traditional project finance structure, with approximately $80 \%$ debt led by Société Générale of Paris, France, and KeyBank National Association of Cleveland, Ohio. Green Giraffe served as a financial advisor for commercial arrangements. The 5-turbine project is expected to be online by the end of 2016, reflecting a nearly 2-year construction period, and is expected to have a 25 year operating life.

- The DOE Wind Program selected three offshore wind projects to conduct design, fabrication, and deployment to achieve commercial operation by 2017 . Each project is eligible for up to $\$ 46.7$ million in funding over 4 years, subject to congressional appropriations and annual progress reviews. These projects include Dominion Virginia Power's two 6-MW wind turbines (Virginia), Fishermen's Energy Atlantic City Windfarm's 20-MW project (New Jersey), and Principle Power's 30-MW project (Oregon) (DOE 2015a)

- In March 2015, DOE released its Wind Vision report, which contains insights from various leaders in the energy business. The report provides direction on how to accelerate the development of next-generation wind power technologies and offers assistance in solving market challenges. DOE recognizes that offshore wind is poised to launch and offers significant potential. In the report, pathways to address critical offshore wind risk factors are addressed and should lead to an improved risk profile for these projects and a concomitant reduction in the cost of capital (DOE 2015b).

- Multiple other federal, state, and industry efforts are under way and focused on reducing the cost of offshore wind in the United States. A detailed list and description can be found in the 2014-2015 Offshore Wind Technologies Market Report (Smith et al. 2015).

Although these factors are positive for the offshore wind industry, several events were clear setbacks for the industry. First, federal tax incentives (e.g., PTC, ITC, and bonus depreciation) have effectively expired for projects that have not met the IRS definition of "start of construction". These incentives, which industry expects to be reinstated, are considered essential to the economic and financial viability of wind projects, and particularly, the more capital-intensive offshore industry. Without action to revive one or both of these programs, investors are unlikely to pursue investment in new offshore wind projects. Second, the cancellation of the PPAs for Cape Wind primarily because of lack of progress and financing did not help the industry. Although Cape Wind appears to be challenging the PPA termination, it is evident that domestic offshore wind continues to face considerable risk in the development phase of the project lifecycle. 


\subsubsection{Risk and Description of Risk Factors}

As of 2015, no offshore wind projects have been installed in the United States, which creates substantial uncertainty for investors even though U.S. projects will be able to leverage 25 years of European experience. U.S. offshore wind project developers have identified risk, and its impacts on the availability and cost of capital, as a key barrier to the implementation of planned projects (Lannard 2011).

Table 20 provides risk categories, specific examples, and mitigation strategies that developers are adopting (Guillet 2007, Mous 2010, Tassin 2010, Claveranne 2011).

Table 20. Offshore Project Risk Categories and Mitigation Strategies

\begin{tabular}{|c|c|c|}
\hline $\begin{array}{l}\text { Risk } \\
\text { Category }\end{array}$ & Description/Examples & Mitigation Strategies \\
\hline $\begin{array}{l}\text { Development } \\
\text { Risk }\end{array}$ & $\begin{array}{l}\text { - Project viability } \\
\text { - Permits } \\
\text { - Power offtake } \\
\text { - Sufficient capital for development } \\
\text { - Debt versus equity ratios }\end{array}$ & $\begin{array}{l}\text { - Community engagement } \\
\text { - Robust project management } \\
\text { - Sponsor commitments } \\
\text { - Due diligence to ensure that all permits, } \\
\text { licenses, and authorizations are in force }\end{array}$ \\
\hline Financing Risk & $\begin{array}{l}\text { - Attract sufficient debt/equity } \\
\text { capital to cover project investment } \\
\text { - Once operational, revenue } \\
\text { must cover payment obligations }\end{array}$ & $\begin{array}{l}\text { - Planning, engaging likely financiers early } \\
\text { - Diligent permitting/contract structuring } \\
\text { - Fixed price for generated power } \\
\text { - Conservative, validated estimates }\end{array}$ \\
\hline $\begin{array}{l}\text { Construction } \\
\text { Risk }\end{array}$ & $\begin{array}{l}\text { - Delays and cost overruns } \\
\text { - Currency risk/commodity price risk } \\
\text { - Severe weather } \\
\text { - Contractor delays } \\
\text { - Accidents } \\
\text { - Responsibility for problems (liability) } \\
\text { - Limited EPC wraps for offshore wind } \\
\text { - Multiparty contracts have interfaces } \\
\text { between contracts in which liability for risk } \\
\text { events may be unclear }\end{array}$ & $\begin{array}{l}\text { - Analysis of downside scenarios } \\
\text { - Preparation of contingency fund } \\
\text { - Insurance } \\
\text { - Strong contracts-identification of } \\
\text { interfaces and clear allocation of } \\
\text { responsibility } \\
\text { - Due diligence to validate design, } \\
\text { engineering }\end{array}$ \\
\hline $\begin{array}{l}\text { Operations } \\
\text { Risk }\end{array}$ & $\begin{array}{l}\text { - Lower availability } \\
\text { - Turbine accessibility } \\
\text { - Vessel availability } \\
\text { - Limited operational experience } \\
\text { with new turbines } \\
\text { - Cost overruns } \\
\text { - Accidents } \\
\text { - Serial design flaws in early } \\
\text { projects (e.g., monopile grout) } \\
\text { - New turbine technology (5 MW+) } \\
\text { - Limited long-term track record }\end{array}$ & $\begin{array}{l}\text { - Smart warranty design with emphasis } \\
\text { on revenue protection } \\
\text { - Long-term service agreement } \\
\text { - OEM commitment } \\
\text { - Insurance } \\
\text { - Conservative planning and budgeting } \\
\text { - Due diligence to validate assumptions }\end{array}$ \\
\hline
\end{tabular}




\begin{tabular}{|c|c|c|}
\hline $\begin{array}{l}\text { Risk } \\
\text { Category }\end{array}$ & Description/Examples & Mitigation Strategies \\
\hline Volume Risk & $\begin{array}{l}\text { - Energy production lower than } \\
\text { expected } \\
\text { - Lower wind resource } \\
\text { - Availability } \\
\text { - Array effects, losses } \\
\text { - Curtailments }\end{array}$ & $\begin{array}{l}\text { - Conservative wind resource estimates } \\
\text { - Insurance } \\
\text { - Priority dispatch agreement } \\
\text { - Due diligence to validate assumptions }\end{array}$ \\
\hline Price Risk & $\begin{array}{l}\text { - Lower prices than forecast } \\
\text { - Changes to regulations or } \\
\text { incentives } \\
\text { - Court cases challenging offtake } \\
\text { contract } \\
\text { - Market volatility }\end{array}$ & $\begin{array}{l}\text { - Fixed price contract (PPA or feed-in tariff) } \\
\text { - Conservative projections }\end{array}$ \\
\hline
\end{tabular}

As offshore wind projects are implemented in Europe, and with the first U.S. project under construction, investors are using lessons learned to develop effective strategies to manage their risk exposure. European governments have historically helped investors to gain comfort with the technology by offering public loans or loan guarantees to reduce exposure to downside risks, designing incentives to provide revenue certainty, and protecting offshore wind generation from curtailment. The European strategy may be effective; 18 commercial banks participated in the 2014 market as compared to 14 commercial banks in 2013.

The lack of installed offshore wind projects in the United States creates uncertainty about the ability of the nascent industry to deliver projects within the planned budget. In addition, there is the added risk of how an offshore wind project will be treated in the untested U.S. regulatory framework. The lack of experience means that investors cannot, with reasonable accuracy, identify the probability of an unfavorable event or the potential impact that such an event could have on project cash flows. Such ambiguity makes investors uncomfortable and limits enthusiasm to commit unsecured capital to the early offshore wind projects. The initial experience financing the Block Island Wind Farm, however, shows that investors are willing to finance strong projects with long-term offtake agreements.

\subsubsection{Financing Rates for Offshore Wind Projects in the United States}

The costs of offshore wind projects exceed market prices and therefore cannot compete with more established technologies on the wholesale market. Consequently, a fixed-price PPA is required for financial viability. Sponsors and lenders are expected to require a guaranteed price for generated power before they are willing to move forward with the substantial capital investment required to build an offshore wind project.

PPAs for U.S. offshore wind projects were recently characterized in the Wind Vision report (DOE 2015b). Four offshore wind PPAs were approved to date, and all four were motivated, to an extent, by state-level policy support. Three of these PPAs have since been canceled. Effective bundled prices ranged from approximately $\$ 180$ to $\$ 240 / \mathrm{MWh}$, with terms extending between 15 and 25 years. Compared to the typical land-based PPA price in the range of $\$ 23$ to $\$ 84 / \mathrm{MWh}$, these PPAs are indicative of the significant capital cost requirement for offshore wind (DOE 2015b). The 
industry's main focus is on working with stakeholders at the state level to create conditions that would lead to viable revenue mechanisms.

Note that the New York Offshore Wind Cost Reduction Study included the following current financing assumptions (Roeth et al. 2015):

- Economic life of 25 years

- Cost of debt ranging from $5 \%$ to $6 \%$

- Cost of equity ranging from $11 \%$ (permanent) to $15 \%$ (construction)

- WACC ranging from $7 \%$ to $8 \%$ based on $55 \%$ to $65 \%$ leveraging.

Focusing attention on the Block Island project as the only project to move forward with financing, Deepwater Wind agreed with the Rhode Island Public Utilities Commission to open its books to the regulators and accept an upper limit to the rate of return of approximately $10.5 \%$ (blended, nominal, after tax). This would reflect a premium of $0.5 \%$ to $1.5 \%$ over the yield target of $9.0 \%$ to $10.0 \%$ for a typical land-based wind project as described in Section 4.6.

Because financing structures for offshore wind projects in the United States are highly uncertain, the following three scenarios are considered.

\section{Scenario 1: Equity (With Back-Leverage)}

The first scenario assumes that the capital structure is consistent with one of the U.S. land-based wind scenarios. Only tax equity and cash equity are used at the project level, and the sponsor secures a loan at the sponsor or holding company level against the receivables of the project. Tax equity is assumed to require a $1 \%$ premium on yield above land-based wind, with $55 \%$ of the capital structure at an $8 \%$ yield. Sponsor yield target is $18 \%$ and bank debt interest rate is $6.0 \%$, making up approximately $63 \%$ of the nontax equity contribution to the project cost.

\section{Scenario 2: Nonrecourse Project Finance (Debt and Equity Mix)}

Current trends in Europe to finance using a more traditional nonrecourse or limited-recourse project finance approach may be consistent with U.S. sponsors who are limited in their ability to finance based on their balance sheets. On the surface, the Block Island project appears to have been leveraged at a ratio above $70 \%$, but for the purposes of this report, a range may be between $50 \%$ and $70 \%$ leverage, with $60 \%$ leverage reflected in the base case. In addition, it is assumed that debt will be priced at $5.0 \%$ interest and equity will demand a premium yield of $15.0 \%$ given coexistence with debt.

\section{Scenario 3: Balance Sheet and Institutional Investment}

Recognizing another European trend, certain domestic sponsors or foreign entrants may be able to fund all or a portion of construction on their balance sheets with additional investment coming from institutional money (pension funds, for example) after the project begins operation. For this scenario, it is assumed that the sponsor's equity target will be $8.9 \%$ for $30.0 \%$ of the capital structure, and institutional investors will be willing to contribute $70.0 \%$ of capital at a $6.5 \%$ yield. 


\subsubsection{Discount Rate}

Previous evaluations of the discount rate for the offshore wind finance study have focused on the European experience and on the blended discount rate of approximately $10.5 \%$ proposed by Cape Wind and Deepwater Wind for their respective project return limits. Although it is evident that an individual project's financing terms will reflect the individual risk profile of that project, new baseline assumptions and ranges of nominal discount rates for offshore wind have been developed based largely on market observations from the European market, as well as available information about financing for the Block Island Wind Farm in the United States. Underlying assumptions for marginal tax rate and inflation are consistent with those presented in Section 4.6.

Base case discount rates reflecting the three financing scenarios for the representative wind project in 2014 are shown in Table 21.

Table 21. Offshore After-Tax Discount Rates in 2014

\begin{tabular}{|lcc|}
\hline Scenario & Nominal Discount Rate & Real Discount Rate \\
\hline Scenario \#1 (Equity with back-leverage) & $8.2 \%$ & $6.0 \%$ \\
\hline Scenario \#2 (Nonrecourse project finance) & $10.2 \%$ & $8.0 \%$ \\
\hline Scenario \#3 (Balance sheet) & $7.2 \%$ & $5.1 \%$ \\
\hline
\end{tabular}

\subsubsection{Economic Evaluation Metrics}

To determine the LCOE for the 2014 representative offshore wind project, an FCR was used (see Section 4.6). The FCR includes the present value of the accumulated depreciation benefit and ignores bonus depreciation. Assuming a project life of 20 years and discount rates and depreciation benefits as calculated, Table 22 presents the FCR for the three contemplated scenarios. The details and calculations for the three scenarios are summarized in Appendix B.

Table 22. Offshore After-Tax Fixed Charge Rates in 2014

\begin{tabular}{|lcc|}
\hline Scenario & Nominal FCR & Real FCR \\
\hline Scenario \#1 (Equity with back-leverage) & $11.6 \%$ & $9.8 \%$ \\
\hline Scenario \#2 (Nonrecourse project finance) & $13.6 \%$ & $11.7 \%$ \\
\hline Scenario \#3 (Balance sheet) & $10.6 \%$ & $9.0 \%$ \\
\hline
\end{tabular}

\subsection{Offshore Wind Reference Project Summary}

The resources, database, and analysis described in this section informed the creation of the reference project shown in Table 23. The 2014 reference project is defined with 148 turbines on monopile foundations and an average water depth of $15 \mathrm{~m}$. In addition, turbines rated at $3.39 \mathrm{MW}$ with a 115.4-m rotor diameter and 85.8- $\mathrm{m}$ hub heights were assumed. The average wind speed at the project site was assumed to be $8.4 \mathrm{~m} / \mathrm{s}$ at $50 \mathrm{~m}$ and $8.87 \mathrm{~m} / \mathrm{s}$ at the $85.8-\mathrm{m}$ hub height (typical North Atlantic wind regime). ${ }^{21}$ This gave the U.S. offshore reference project an AEP of 3,716 $\mathrm{MWh} / \mathrm{MW} / \mathrm{yr}$, which is a net capacity factor of $42.4 \%$.

\footnotetext{
${ }^{21}$ Average wind speed based on a Weibull $(\mathrm{k}=2.1)$ probability distribution.
} 
These turbine parameters are characteristics that are specific to the turbine and independent of the wind characteristics. These parameters consist not only of turbine size (such as rated power, rotor diameter, and hub height), but also of turbine operating characteristics (such as coefficient of power $\left[\mathrm{C}_{\mathrm{p}}\right]$, maximum tip speed, maximum TSR, and drivetrain design). Because the three-stage planetary/helical gearbox with a high-speed asynchronous generator style drivetrain topology dominates the global market, it was selected for the baseline turbines used in this analysis.

In the reference project layout, the turbines are spaced in a grid formation at 8 rotor diameters apart and connected to the substation using a radial 33-kilovolt collection system design and a 220kilovolt export system. Reference project costs for 2014 were based on global average market data and NREL models. The CapEx of the project were estimated to be $\$ 2.97$ billion, or about $\$ 5,925 / \mathrm{kW}$, including a contingency estimated at $10 \%$ of installed capital costs. The annual OpEx are equivalent to $\$ 37 / \mathrm{MWh}$, or $\$ 138 / \mathrm{kW} / \mathrm{yr}$.

The reference project WACC, or discount rate used to finance the project, was from Scenario \#1 (equity with back-leverage) and estimated to be $8.2 \%$ nominal after tax (equivalent to $6.0 \%$ real after-tax), resulting in a real FCR equal to $9.8 \%$. Scenarios \#2 and \#3 were used in the LCOE sensitivity analysis to be discussed in Section 5.8 .

Table 23. Fixed-Bottom Offshore Reference Project Assumptions Summary

\begin{tabular}{|c|c|}
\hline \multicolumn{2}{|l|}{ General Assumptions } \\
\hline Project capacity (MW) & 502 \\
\hline Number of turbines & 148 \\
\hline Turbine capacity (MW) & 3.39 \\
\hline \multicolumn{2}{|l|}{ Site } \\
\hline Location & North Atlantic Coast (U.S.) \\
\hline Depth (m) & 15 \\
\hline Distance from shore $(\mathrm{km})$ & 20 \\
\hline Wind speed $(\mathrm{m} / \mathrm{s}$ at $50 \mathrm{~m}$ above mean sea level) & 8.4 \\
\hline Wind speed $(\mathrm{m} / \mathrm{s}$ at $90 \mathrm{~m}$ above mean sea level) & 8.87 \\
\hline Net capacity factor & $42.4 \%$ \\
\hline \multicolumn{2}{|l|}{ Technology } \\
\hline Rotor diameter (m) & 115.4 \\
\hline Tower height (m) & 85.8 \\
\hline Gearbox & Three stage \\
\hline Generator & Asynchronous \\
\hline Foundation & Monopile \\
\hline
\end{tabular}




\begin{tabular}{|lc|}
\hline \multicolumn{2}{|c|}{ Cost } \\
\hline Capital cost (millions) & $\$ 2,973$ \\
\hline Contingency $(10 \%$ of hard costs in million $\$)$ & $\$ 266$ \\
\hline Annual OpEx (\$/MWh) & $\$ 37$ \\
\hline Discount rate (real) & $6.0 \%$ \\
\hline Discount rate (nominal) & $8.2 \%$ \\
\hline Operating life (years) & 20 \\
\hline FCR (real) & $9.8 \%$ \\
\hline
\end{tabular}

\subsection{Offshore Wind Levelized Cost of Energy Calculation}

Table 24 summarizes the offshore wind technology reference project by providing the component cost categories for the 3.39-MW turbines in the project as well as the LCOE calculation results. A comprehensive summary of assumptions can be found in Appendix A. Estimates of the percentage contribution of individual project components to total capital costs were developed for each component based on the aforementioned global offshore market data and NREL cost models. The NREL Offshore Wind Database (NREL 2013) and cost models enable the development of an improved understanding of scaling relationships and opportunities for technology improvement.

Table 24. Fixed-Bottom Offshore Wind LCOE and Reference Project Cost Breakdown

\begin{tabular}{|ccc|}
\hline & $\begin{array}{c}\text { 3.39-MW Offshore } \\
\text { Turbine }\end{array}$ & $\begin{array}{c}\text { 3.39-MW Offshore } \\
\text { Turbine }\end{array}$ \\
\hline CapEx & $\$ 5,925 / \mathrm{kW}$ & $\$ 129 / \mathrm{MWh}$ \\
\hline OPER & $\$ 52 / \mathrm{kW} / \mathrm{yr}$ & $\$ 14 / \mathrm{MWh}$ \\
\hline MAIN & $\$ 86 / \mathrm{kW} / \mathrm{yr}$ & $\$ 23 / \mathrm{MWh}$ \\
\hline OpEx & $\$ 138 / \mathrm{kW} / \mathrm{yr}$ & $\$ 37 / \mathrm{MWh}$ \\
\hline AEP & & 3,716 \\
\hline Net capacity factor & & $42.4 \%$ \\
\hline FCR (real, after tax) & & $9.8 \%$ \\
\hline LCOE (\$/MWh) & \multicolumn{3}{|c|}{$\mathbf{1 9 3}$} \\
\hline
\end{tabular}

The 2014 NREL reference offshore wind project has an LCOE of \$193/MWh. Figure 20 shows the cost breakdown for the project. 


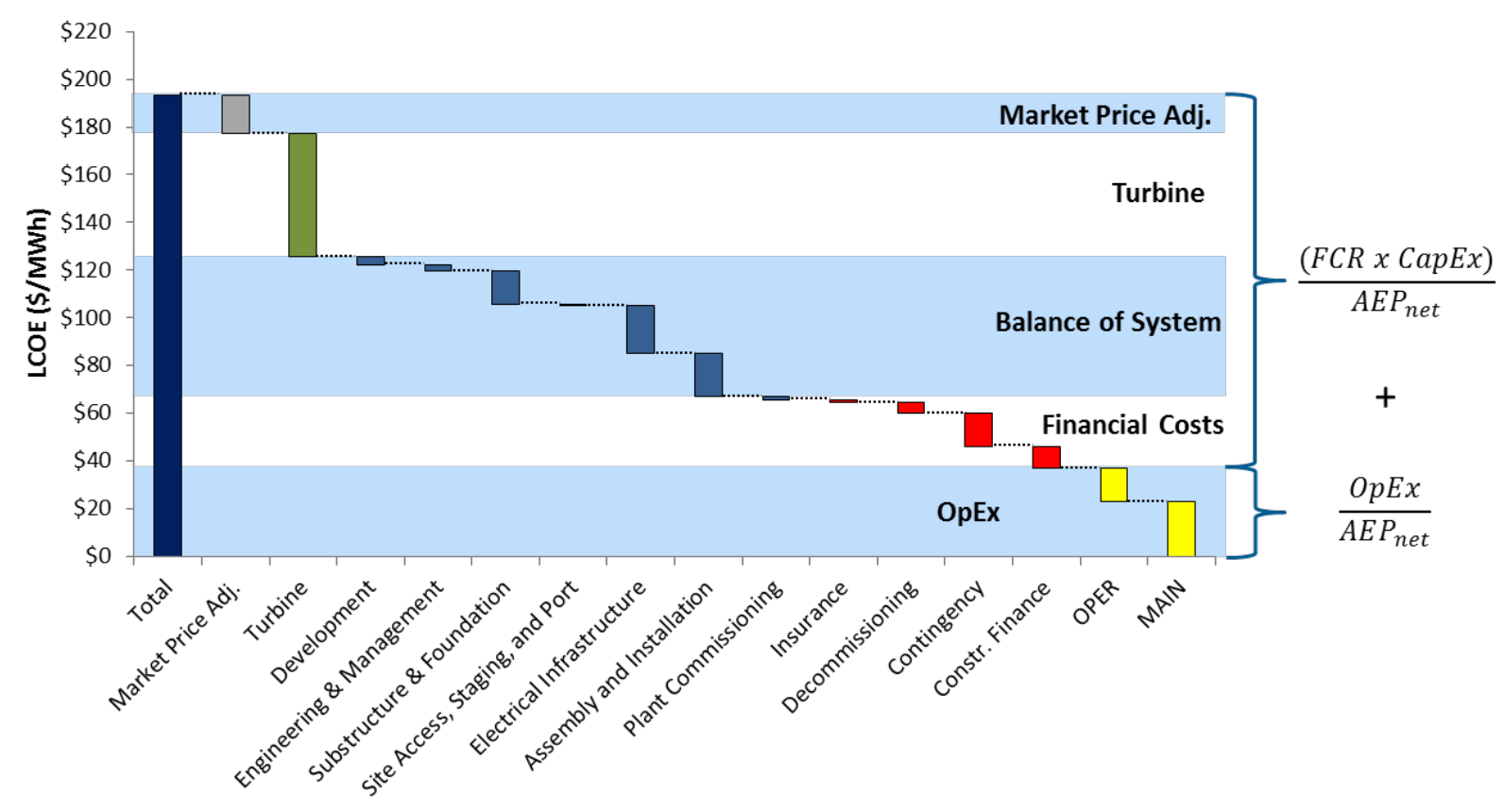

Figure 20. Cost breakdown for the 2013 offshore wind reference project

Source: NREL

\subsection{Offshore Wind Levelized Cost of Energy Sensitivities}

The costs and operational parameter inputs of a near-term offshore wind project are subject to considerable uncertainty similar to that for land-based projects. The sensitivity analysis shown in Figure 23 focuses on the basic LCOE inputs: CapEx, OpEx, capacity factor (a surrogate for AEP), and FCR. In Figure 10, though, discount rate and operational lifetime represent FCR. Sensitivities were tested using the observed ranges described previously and by holding all other variables constant. In Figure 21, the reference estimate for each parameter is represented by the vertical white line within each bar. Specific high and low values are shown within each colored bar. 


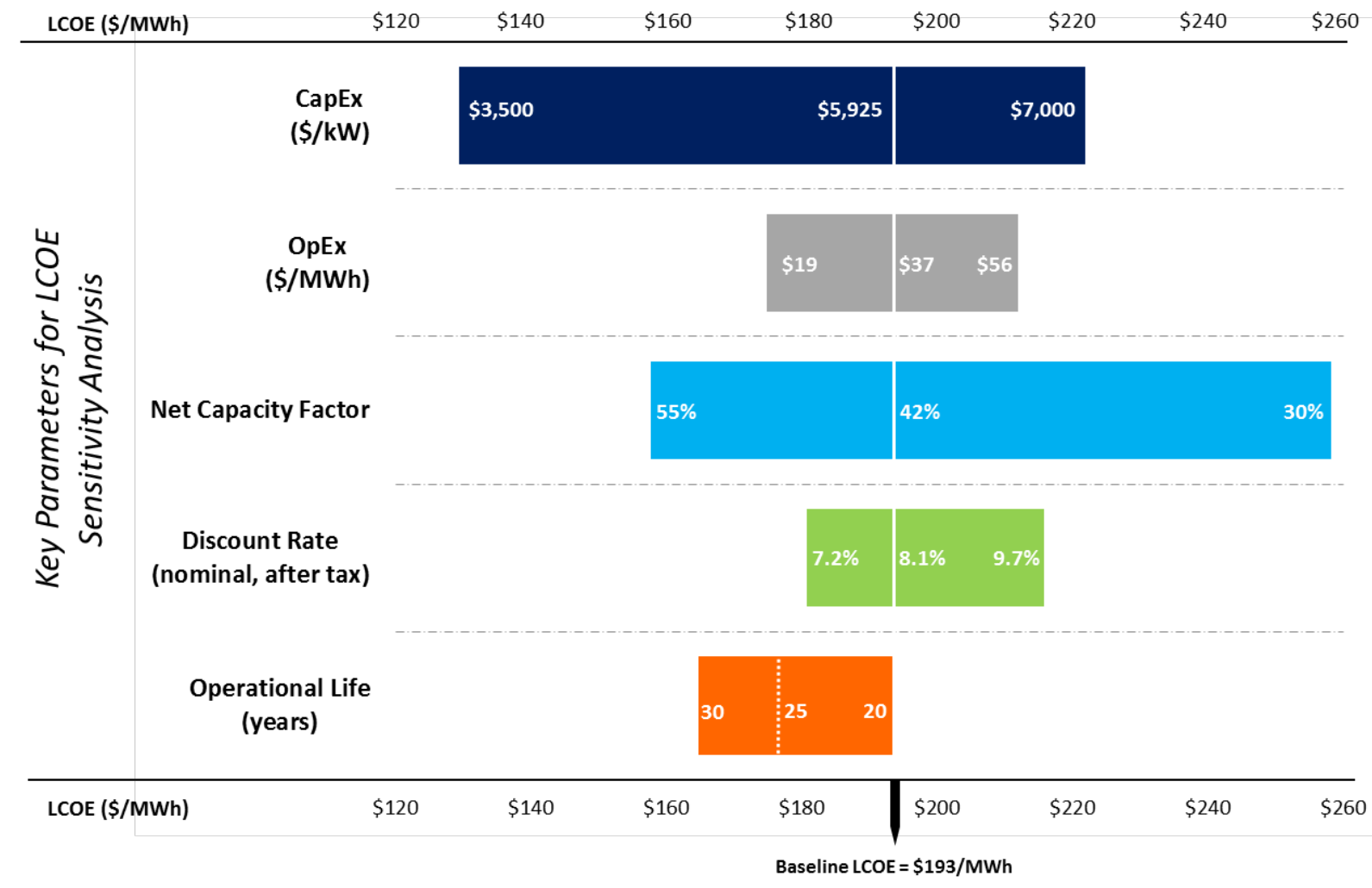

Figure 21. Sensitivity of offshore wind LCOE to key input parameters

Source: NREL

Note: The reference LCOE provides a representative estimate of the offshore wind LCOE, assuming commercial-scale fixed-bottom technology. Changes in LCOE for a single variable can be understood by moving to the left or right along a specific variable. Values on the $\mathrm{x}$-axis indicate how the LCOE will change as a given variable is altered and assuming that all others are constant (i.e., the variables remain reflective of the reference project).

During the analysis, sensitivity ranges were selected to represent the highs and lows seen in the industry. This selection of ranges provides insight into how real-world variability influences LCOE. Figure 23 shows a very wide range of LCOE outcomes, extending from \$129 to $\$ 258 / \mathrm{MWh}$; however, as noted in the previous discussion of land-based sensitivities, the high and low LCOE ranges should not be taken as absolute because these variables are not typically independent. For offshore wind projects, the COE is most sensitive to CapEx and capacity factors, and appears to be less sensitive to operating life, discount rate, and OpEx. 


\section{Historical Modeled Levelized Cost of Wind Energy}

DOE set LCOE goals in 2010 as research and development targets for 2020 and 2030. Since then, NREL has been assessing the LCOE. Table 25 and Table 26 summarize the trends of land-based LCOE and offshore LCOE, respectively. The LCOE values are reported annually in nominal dollars to represent the actual cost of energy for a given year. The primary LCOE inputs driving these results are included in the tables.

In Table 25 and Table 26, LCOE results in 2010 and 2011 differ from the NREL published reports for those years because of the changes in the methodology for OpEx. In the previous cost of wind energy reviews, the authors used an after-tax operational expenditure that affected the labor, equipment, and facilities portion of the OpEx. The methodology of using only a pretax value was established in 2012 because rules and regulations differ based on the specific project location. To compare the historical LCOE values and represent the trends, the 2010 and 2011 OpEx were modified to align with the current methodology.

Land-based wind plant LCOE estimates continue to show a downward trend from the 2010 Cost of Wind Energy Review (Tegen et al. 2012) to 2014. Offshore turbine costs show similar cost reductions; however, the decrease in LCOE for land-based projects can be attributed more to the turbine technology, whereas the offshore decrease in LCOE is related to the changes in financing considerations of projects installed in Europe. DOE's levelized cost of energy goals (in 2010 dollars) and graphs showing the trends can be found in Appendix C.

Table 25. Historical Land-Based LCOE in Nominal Dollars

\begin{tabular}{|l|c|c|c|c|c|}
\hline Parameters & 2010 COE & 2011 COE & 2012 COE & 2013 COE & 2014 COE \\
\hline Nameplate capacity (MW) & 1.5 & 1.5 & 1.94 & 1.9 & 1.94 \\
Rotor diameter (m) & 82.5 & 82.5 & 93.5 & 96.9 & 99.4 \\
Hub height $(\mathrm{m})$ & 80 & 80 & 80 & 82.7 & 82.7 \\
Modeled net capacity factor $(\%)$ & 38.0 & 37.0 & 37.5 & 38.5 & 39.6 \\
\hline CapEx (\$/kW) & 2,155 & 2,098 & 1,940 & 1,728 & 1,710 \\
FCR (\%) & 9.5 & 9.5 & 9.5 & 10.2 & 10.3 \\
OpEx (\$/kW/yr) & 55 & 55 & 55 & 50 & 50 \\
AEP (MWh/MW/yr) & 3,345 & 3,263 & 3,284 & 3,410 & 3,466 \\
\hline LCOE (\$/MWh) & $\mathbf{7 8}$ & $\mathbf{7 8}$ & $\mathbf{7 3}$ & $\mathbf{6 6}$ & $\mathbf{6 5}$ \\
\hline
\end{tabular}


Table 26. Historical Offshore LCOE in Nominal Dollars

\begin{tabular}{|l|c|c|c|c|c|}
\hline Parameters & 2010 COE & 2011 COE & 2012 COE & 2013 COE & 2014 COE \\
\hline Nameplate capacity (MW) & 3.6 & 3.6 & 3.6 & 4.3 & 3.39 \\
Rotor diameter (m) & 107 & 107 & 107 & 119.4 & 115.4 \\
Hub height $(\mathrm{m})$ & 90 & 90 & 90 & 89.5 & 85.8 \\
Modeled net capacity factor $(\%)$ & 39.0 & 39.0 & 39.0 & 39.0 & 42.4 \\
\hline CapEx (\$/kW) & 5,600 & 5,600 & 5,384 & 5,187 & 5,925 \\
FCR (\%) & 11.7 & 11.7 & 11.7 & 11.7 & 9.8 \\
OpEx (\$/kW/yr) & 136 & 136 & 136 & 136 & 138 \\
AEP (MWh/MW/yr) & 3,406 & 3,406 & 3,406 & 3,463 & 3,716 \\
\hline LCOE (\$/MWh) & $\mathbf{2 3 2}$ & $\mathbf{2 3 2}$ & $\mathbf{2 2 5}$ & $\mathbf{2 1 5}$ & $\mathbf{1 9 3}$ \\
\hline
\end{tabular}




\section{Conclusions}

The results and analysis in this technical report led to the following conclusions:

- Final LCOE estimates continue to show a downward trend from the 2010 Cost of Wind Energy Review (Tegen et al. 2012) to 2014. Offshore turbine costs have shown similar cost reductions; however, the decrease in LCOE for land-based projects can be attributed more to the turbine technology, whereas the decrease in offshore LCOE can be a result of the BOS costs.

- The reference project LCOE for land-based installations was observed to be $\$ 65 / \mathrm{MWh}$, and the full range of land-based estimates covers \$51-\$145/MWh.

- The reference project offshore LCOE estimate is \$193/MWh, with a full range of \$129$\$ 258 / \mathrm{MWh}$. This dramatic range is mostly caused by the large variation in capital expenditures $(\$ 3,500-\$ 7,000 / \mathrm{kW})$ reported by project developers.

- The sensitivity analysis shows that LCOE can vary widely based on changes in any one of several key factors; however, the variable with the most dramatic effect on LCOE is capacity factor, which is the case for both land-based and offshore projects.

- National and regional supply curves illustrate that there is a significant range of LCOE across the country when wind turbine technology is matched with wind resource conditions, suggesting that factors beyond least cost drive wind project realization.

This analysis presents a picture of the levelized cost of land-based and offshore wind energy using real and modeled data that represent 2014 market conditions. Scenario planning and modeling activities often focus on one number (or cost) for land-based LCOE and one for offshore LCOE. In reality, the cost of land-based wind energy varies greatly across the United States and offshore wind LCOE varies significantly across Europe and Asia (Table 27).

The LCOE analysis presented in this report is only one way to measure the cost of wind energy. It does not include other costs and price issues that influence a given wind project's viability, such as transmission, environmental impacts, military constraints, or other areas of consideration (e.g., public policy, consumer costs, energy prices, or public acceptance). In addition, these LCOE estimates do not reflect the value of electricity, incentives, or other policy mechanisms (such as PTCs or ITCs) that affect the sales price of electricity produced from wind projects.

Table 27. Range of LCOE for U.S. Land-Based and Offshore Wind in 2013

\begin{tabular}{|lcc|}
\hline CapEx & Land-Based Wind Projects & Offshore Wind Projects \\
\hline OpEx & $\$ 1,396-\$ 3,176 / \mathrm{kW}$ & $\$ 3,500-\$ 7,000 / \mathrm{kW}$ \\
\hline Capacity factor & $\$ 4-\$ 30 / \mathrm{MWh}$ & $\$ 19-\$ 56 / \mathrm{MWh}$ \\
\hline Discount rate & $18 \%-51 \%$ & $30 \%-55 \%$ \\
\hline Operational life & $5.5 \%-11.0 \%$ & $7.2 \%-10.2 \%$ \\
\hline Range of LCOE & $20-30$ years & $20-30$ years \\
\hline
\end{tabular}




\section{Related and Future Work}

NREL continues to work to gain a better understanding of costs associated with many components of land-based wind turbines and systems. Ongoing collaboration with industry would lead to better data, enhanced modeling capabilities, and increased awareness of current and future wind power system component costs. For offshore wind, this analysis provides an analytically solid estimate for potential domestic wind power projects.

NREL intends to update this review of wind energy costs on an annual basis. These updates are intended to help maintain a perspective on costs that are grounded in real-time market changes as well as offer greater insight into the costs and performance of individual components related to the wind generation system. In addition, these reports are intended to provide greater clarity regarding wind energy costs and the effects of changes in specific variables on the LCOE. The data and tools developed from this work will be used to help inform projections, goals, and improvement opportunities. As the industry evolves and matures, NREL will continue to publish current representative project data and LCOE estimates for scenario planning, modeling, and goal setting.

Future work entails three primary objectives: 1) continuing to enhance data representing marketbased costs, performance, and technology trends to reflect actual wind industry experience; 2) enhancing the fidelity of bottom-up cost and performance estimation for individual wind plant components; and 3) understanding sensitivities to factors such as regional differences, site characteristics, and technology choices. In 2015 and going forward, NREL will continue to work with industry partners and national laboratories to obtain project-specific data to validate and improve models. NREL's ongoing wind analysis efforts include:

- Creating a model to better represent offshore nonturbine project costs, such as foundations, electrical cabling, and installation, across a range of turbine and project sizes

- Developing a wind energy systems engineering model to conduct enhanced analysis of new innovation impacts on turbine cost and performance.

In addition, NREL plans to:

- Update the NREL wind turbine design Cost and Scaling Model with improved turbinespecific data

- Investigate and estimate the cost of offshore wind energy on floating platforms and compare to fixed-bottom foundation substructures

- Estimate the effect on LCOE from anticipated improvements to O\&M in both land-based and offshore wind projects

- Continue work on computational fluid dynamics models to determine the magnitude and impact of wake losses

- Quantify the effect of potential technology pathways on system LCOE for land-based and offshore wind technology. 


\section{References}

American Wind Energy Association (AWEA). 2014. New analysis: U.S. is world's number one wind energy producer, leading China and Germany. Washington. Accessed May 2015. http://www.awea.org/MediaCenter/pressrelease.aspx? ItemNumber=6965.

AWEA. Undated "Project Database," Accessed April 2015. http://stats.awea.org (link requires membership).

AWEA. 2015. “AWEA U.S. Wind Industry Annual Market Report Year Ending 2014.” Accessed February 2015. http://www.awea.org/AMR2014.

AWS TruePower. 2015. "Annual average wind speed $(\mathrm{m} / \mathrm{s})$ at $80 \mathrm{~m}$ hub height, modeled using AWS's mesoscale modeling system. Spatial resolution $2.5 \mathrm{~km}$, interpolated by AWS to a $200 \mathrm{~m}$ resolution." https://www.awstruepower.com/.

Barr, A., D. Shreve, L. Lewandowski, and N. Heschung. 2013. Global Wind Turbine Trends 2013. MAKE Consulting.

Beamon, A., and M. Leff. 2013. EOP III Task 1606, Subtask 3 - Review of Power Plant Cost and Performance Assumptions for NEMS. Prepared by SAIC Energy, Environment \& Infrastructure, LLC for the Energy Information Administration, Office of Energy Analysis. Accessed April 2013. http://www.eia.gov/forecasts/capitalcost/pdf/updated_capcost.pdf.

Blair, N., K. Cory, M. Hand, L. Parkhill, B. Speer, T. Stehly, D. Feldman, E. Lantz, C. Augustine, C. Turchi, and P. O'Connor. 2015. Annual Technology Baseline. Golden, CO: National Renewable Energy Laboratory. Report No. NREL/PR-6A20-64077. Accessed July

2015. http://www.nrel.gov/docs/fy15osti/64077.pdf.

Bloomberg New Energy Finance (BNEF). 2012. "Levelized Cost of Electricity Update: Q3 2012." Energy - Research Note. July 18, 2012.

BNEF. 2014. “H2 2014 Offshore Wind Market Outlook.” September 2, 2014.

BNEF. 2015. “H1 2015 North America Wind Market Outlook.” April 9, 2015.

Board of Governors of Federal Reserve System. 2015. "Why Does the Federal Reserve Aim for 2 Percent Inflation over Time?" Accessed April

2015. http://www.federalreserve.gov/faqs/economy 14400.htm.

Broehl, J., and M. Ernst. 2014. "Embryonic No More: U.S. Offshore Wind Industry Gaining Momentum." North American Windpower. August 6, 2014. Accessed March 2015. http://nawindpower.com/e107_plugins/content/content.php?author.13273.

Bureau of Labor Statistics. Undated. "FAQ: Is the Consumer Price Index (CPI) The Best Measure of Inflation?” Accessed May 2015. http://www.bls.gov/dolfaq/bls ques6.htm. 
Bureau of Ocean Energy Management (BOEM). 2011. Renewable Energy Program State Activities Web Resources. Washington, DC: U.S. Department of the Interior BOEM. August 2015. http://www.boem.gov/Renewable-Energy-Program/State-Activities/Index.aspx.

BVG Associates. 2011. Guide to an Offshore Wind Farm. The Crown Estate. Accessed August 2013. http://www.thecrownestate.co.uk/media/211144/guide to offshore windfarm.pdf.

Claveranne, P.E. 2011. Presentation at INTPOW Conference - Project Finance for Offshore Wind. Green Giraffe Energy Bankers. INPOW 2nd Offshore Wind Supply Chain Conference. March 22, 2011. Oslo, Norway.

Cohen, J., T. Schweizer, A. Laxson, S. Butterfield, S. Schreck, L. Fingersh, P. Veers, and T. Ashwill. 2008. Technology Improvement Opportunities for Low Wind Speed Turbines and Implications for Cost of Energy Reduction. Technical Report. Golden, CO: National Renewable Energy Laboratory. NREL/TP-500-41036. http://www.nrel.gov/docs/fy08osti/41036.pdf.

Deloitte. 2011. Analysis on the Furthering of Competition in Relation to the Establishment of Large Offshore Wind Farms in Denmark. The Ministry of Climate and Energy (ENS). https://stateofgreen.com/files/download/382.

Douglas-Westwood Ltd. 2010. Offshore Wind Assessment for Norway. Final report. The Research Council of Norway. Accessed August

2012. http://www.nve.no/Global/Energi/Havvind/Vedlegg/Annet/Offshore\%20Wind\%20Asessme nt $\% 20$ For $\% 20$ Norway $\% 20-\% 20$ Final\%20Report $\% 20-\% 20190510 \% 20$ with $\% 20$ dc.pdf.

Electric Power Research Institute (EPRI). 2007. Renewable Energy Technical Assessment GuideTAG-RE: 2006. Accessed May 2007. http://www.epri.com/abstracts/Pages/ProductAbstract.aspx?ProductId=00000000000101272 $\underline{2}$

European Wind Energy Association (EWEA). 2013. "Where's the money coming from? Financing Offshore Wind Farms." ISBN: 978-2-930670-06-5. March

2014. http://www.ewea.org/fileadmin/files/library/publications/reports/Financing Offshore Wind Farms.pdf.

EWEA. 2015a. "Wind in Power - 2014 European Statistics." February 2015. Accessed February 2015. http://www.ewea.org/fileadmin/files/library/publications/statistics/EWEA-Annual-Statistics2014.pdf.

EWEA. 2015b. "The European Offshore Wind Industry - Key Trends and Statistics 2014." January 2015. Accessed January

2015. http://www.ewea.org/fileadmin/files/library/publications/statistics/EWEA-EuropeanOffshore-Statistics-2014.pdf.

Fingersh, L., M. Hand, and A. Laxson. 2006. Wind Turbine Design Cost and Scaling Model. Technical Report. Golden, CO: National Renewable Energy Laboratory. Report No. NREL/TP500-40566. Accessed August 2012. http:/www.nrel.gov/docs/fy07osti/40566.pdf. 
Freshfields. 2014. European Offshore Wind 2014: Financing the Opportunities. Freshfields Bruckhaus Deringer. Accessed January

2015. http://www.freshfields.com/uploadedFiles/SiteWide/News_Room/Insight/Windfarms/Windf arms_2014/Offshore\%20wind\%20report\%202014.pdf.

Gifford, Jason S., R. Grace, and W. Rickerson. 2011. Renewable Energy Cost Modeling: A Toolkit for Establishing Cost-Based Incentives in the United States, March 2010 -March 2011.

Subcontract Report. Golden, CO: National Renewable Energy Laboratory. Report No. NREL/SR6A20-51093. Accessed August 2012. http://www.nrel.gov/docs/fy11osti/51093.pdf.

Greenacre, Phillip, Gross, Robert, and Heptonstall, Phil. 2010. Great Expectations: The cost of offshore wind in UK waters - understanding the past and projecting the future. UK Energy Research Centre.

https://spiral.imperial.ac.uk/bitstream/10044/1/12649/6/Great\%20Expectations\%20-

$\% 20$ The $\% 20$ cost $\% 20$ of $\% 20$ offshore $\% 20$ wind $\% 20$ in $\% 20$ UK\%20waters.pdf.

Guillet, J. 2007. Offshore Wind: Options for Non-Recourse Financing. Dexia. Accessed December 2014. http://www.aspo-spain.org/aspo7/presentations/Guillet-Wind-ASPO7.pdf.

Guillet, J. 2015. "Nordsee One Reaches Financial Close" Accessed May 28, 2015. http://greengiraffe.eu/article/nordsee-one-reaches-financial-close-press-release

Hamilton, B., M. Bielecki, C. Bloch, T. Decker, L. Frantzis, K. Midura, J. Paidipati, F. Zhao. 2014. Offshore Wind Market and Economic Analysis - 2014 Annual Market Assessment.

Burlington, Massachusetts: Navigant. Accessed August

2014. http://energy.gov/sites/prod/files/2014/09/f18/2014\%20Navigant $\% 20$ Offshore $\% 20 \mathrm{Wind} \% 2$ 0Market $\% 20 \% 26 \% 20$ Economic $\% 20$ Analysis.pdf.

Hand, M., K. Belyeu, E. Lantz, R. Wiser, and M. Bolinger. 2015. "Wind Energy Development in the United States," Chapter 6. ed., IEA Wind Task 26 - Wind Technology, Cost, and Performance Trends in Denmark, Germany, Ireland, Norway, the European Union, and the United States: 2007-2012. Report No. NREL/TP-6A20-64332. Golden, CO: National Renewable Energy Laboratory. pp. 137-160.

Internal Revenue Service (IRS). 2014. Notice 2015-25, "Beginning of Construction for Sections 45 and 48." Accessed March 2015. http://www.irs.gov/pub/irs-drop/n-15-25.pdf.

Lannard, J. 2011. Financing Challenges Facing the US Offshore Wind Market: The Industry Perspective. U.S. Offshore Wind Development Coalition. Accessed August 2012. http://www.cleanenergystates.org/assets/Uploads/FinancingChallengesWebinarJuly13ALL.p df

Lantz, E., Steinberg, D., Mendelsohn, M., Zinaman, O., James, T., Porro, G., Hand, M., Mai, T., Logan, J., Heeter, J., and Bird, L. 2014. Implications of a PTC Extension on U.S. Wind Deployment. Technical Report. Golden, CO: National Renewable Energy Laboratory. Report No TP-6A20-61663. Accessed June 2014. http://www.nrel.gov/docs/fy14osti/61663.pdf. 
Lantz, E., R. Wiser, and M. Hand. 2012. The Past and Future Cost of Wind Energy. Technical Report. Golden, CO: National Renewable Energy Laboratory. Report No. NREL/TP-6A20-53510. Accessed February 2013. http://www.nrel.gov/docs/fy12osti/53510.pdf.

Lazard. 2014. "Lazard's Levelized Cost of Energy Analysis - Version 8.0.” September 2014. Accessed September 2014. http://www.lazard.com/media/1777/levelized cost of energy version 80.pdf.

Malcom, D., and A. Hansen. 2006. WindPACT Turbine Rotor Design Study. Subcontract Report. Golden, CO: National Renewable Energy Laboratory. Report No. NREL/SR-500-32495. Accessed February 2013. http://www.nrel.gov/docs/fy06osti/32495.pdf.

Maples, B., M. Hand, and W. Musial. 2010. Comparative Assessment of Direct Drive High Temperature Superconducting Generators in Multi-Megawatt Class Wind Turbines. Golden, CO: National Renewable Energy Laboratory, 40 pp.; Report No. TP-5000-49086. Accessed December 2010. http://www.nrel.gov/docs/fy11osti/49086.pdf.

Marciano, J., III. 2013. "Synthetic Power Contracts.” Project Finance Newswire. Chadbourne. Accessed May 2015. http://www.chadbourne.com/SyntheticPowerContracts projectfinance/.

Martin, K. 2015. "Cost of Capital: 2015 Outlook." Chadbourne \& Parke, Project Finance NewsWire. February 2015.

Moné, C., A. Smith, B. Maples, and M. Hand. 2015. 2013 Cost of Wind Energy Review. Golden, CO: National Renewable Energy Laboratory, NREL Report No. TP-5000-63267. Accessed March 2015. http://www.nrel.gov/docs/fy15osti/63267.pdf.

Mous, D. 2010.Current and Future Trends in Offshore Wind Financing. NIBC Infrastructure \& Renewables.

National Renewable Energy Laboratory (NREL). 2013. Internal Offshore Wind Project Database. Unpublished.

O’Sullivan, J. 2015. “Two Utilities Opt out of Cape Wind.” The Boston Globe. January 7, 2015. Accessed March 2015. https://www.bostonglobe.com/metro/2015/01/06/major-setback-for-capewind-project/kggnYeAXRj03PyfIUn2iIM/story.html.

Remec, G., C. Howells, F. Grounda, and C. Kuti. 2013. Rating Criteria for Onshore Wind Farm Projects. Fitch Ratings, April 11, 2013.

Roeth, J., S. McClellan, D. Ozkan, K. Kempton, A. Levitt, and H. Thomson. 2015. New York Offshore Wind Cost Reduction Study, Final Report. Prepared for New York State Energy Research and Development Authority. February 2015. Accessed March

2015. http://www.ceoe.udel.edu/File\%20Library/About/SIOW/New-York-Offshore-Wind-CostReduction-Study-ff8-2.pdf.

Settle, E. 2015. "Performance Statistics for Large Wind Farms Befitting from the Treasury 1603 Program.” Unpublished report. 
Short, W., D.J. Packey, and T. Holt. 1995. A Manual for the Economic Evaluation of Energy Efficiency and Renewable Energy Technologies. Golden, CO: National Renewable Energy Laboratory. Report No. NREL/TP-462-5176. Accessed February 2013. http://www.nrel.gov/docs/legosti/old/5173.pdf.

Smith, A., T. Stehly, and W. Musial. 2015. 2014-2015 Offshore Wind Technologies Market Report. NREL/TP-5000-64283. Golden, CO: National Renewable Energy Laboratory. Accessed May 2015. http://www.nrel.gov/docs/fy15osti/64283.

Sullivan, P., C. Wesley, N. Blair, E. Lantz, V. Krishnan, T. Mai, D. Mulcahy, and G. Porro. 2015. 2015 Standard Scenarios Annual Report: U.S. Electric Sector Scenario Exploration. NREL/TP6A20-64072. Golden, CO: National Renewable Energy Laboratory. Accessed July 2015. http://www.nrel.gov/docs/fy15osti/64072.pdf.

Tassin, C. 2010. Financing Offshore Wind Farms: What Can Be Done - and What Works. Dexia. Wind Energy Investor Forum. London. Accessed September 2011. http://www.windenergyinvestorforum.com/2010/pdfs/100609 dexia presentation_offshore financing_v2.pdf.

Tegen, S., M. Hand, B. Maples, E. Lantz, S. Schwabe, and A. Smith. 2012. 2010 Cost of Wind Energy Review. Technical Report. Golden, CO: National Renewable Energy Laboratory. Report No. NREL/TP-5000-52920. Accessed February 2013. http://www.nrel.gov/docs/fy120sti/52920.pdf .

Tegen, S, E. Lantz, M. Hand, B. Maples, A. Smith, and P. Schwabe. 2013. 2011 Cost of Wind Energy Review. Golden, CO: National Renewable Energy Laboratory. Accessed March 2014. http://www.nrel.gov/docs/fy13osti/56266.pdf.

UK Energy Research Center. 2010. Great Expectations: The cost of offshore wind in UK waters - understanding the past and projecting the future. UK Energy Research Centre. ISBN 1 90314409 4. http://www.ukerc.ac.uk/publications/great-expectations-the-cost-of-offshore-windinuk-waters-understanding-the-past-and-projecting-the-future.html.

U.S. Department of Energy (DOE). 2015a. "Offshore Wind Advanced Technology Demonstration Projects.” Accessed May 28, 2015. http://energy.gov/eere/wind/offshore-wind-advancedtechnology-demonstration-projects.

DOE. 2015b. "Wind Vision: A New Era for Wind Power in the United States." Accessed April 2015. http://www.energy.gov/eere/wind/maps/wind-vision.

U.S. Department of the Treasury. Undated. "Resource Center: Daily Treasury Yield Curve Rates." Accessed May 2015. http://www.treasury.gov/resource-center/data-chart-center/interestrates/Pages/TextView.aspx?data=yield.

U.S. Energy Information Administration (EIA). 2015. Annual Energy Outlook 2015 with Projections to 2040. Report No. DOE/EIA-0383(2015). Accessed May

2015. http://www.eia.gov/forecasts/aeo/. 
Wiser, R., and M. Bolinger. 2015. 2014 Wind Technologies Market Report. U.S. Department of Energy, Office of Energy Efficiency and Renewable Energy. Accessed August

2015. http://www.energy.gov/eere/wind/downloads/2014-wind-technologies-market-report.

Wiser, R., E. Lantz, M. Bolinger, and M. Hand. 2012. Recent Developments in the Levelized Cost of Energy from U.S. Wind Power Projects. Lawrence Berkeley National Laboratory/National Renewable Energy Laboratory. Accessed May 2012. http://emp.lbl.gov/sites/all/files/wind-energycosts-2-2012 0.pdf. 


\section{Appendix A. Summary of Assumptions for 2014 Reference Projects}

\section{Land-Based Wind Project Assumptions}

Table A1. Comprehensive List of Assumptions for 2014 Land-Based Reference Project COE

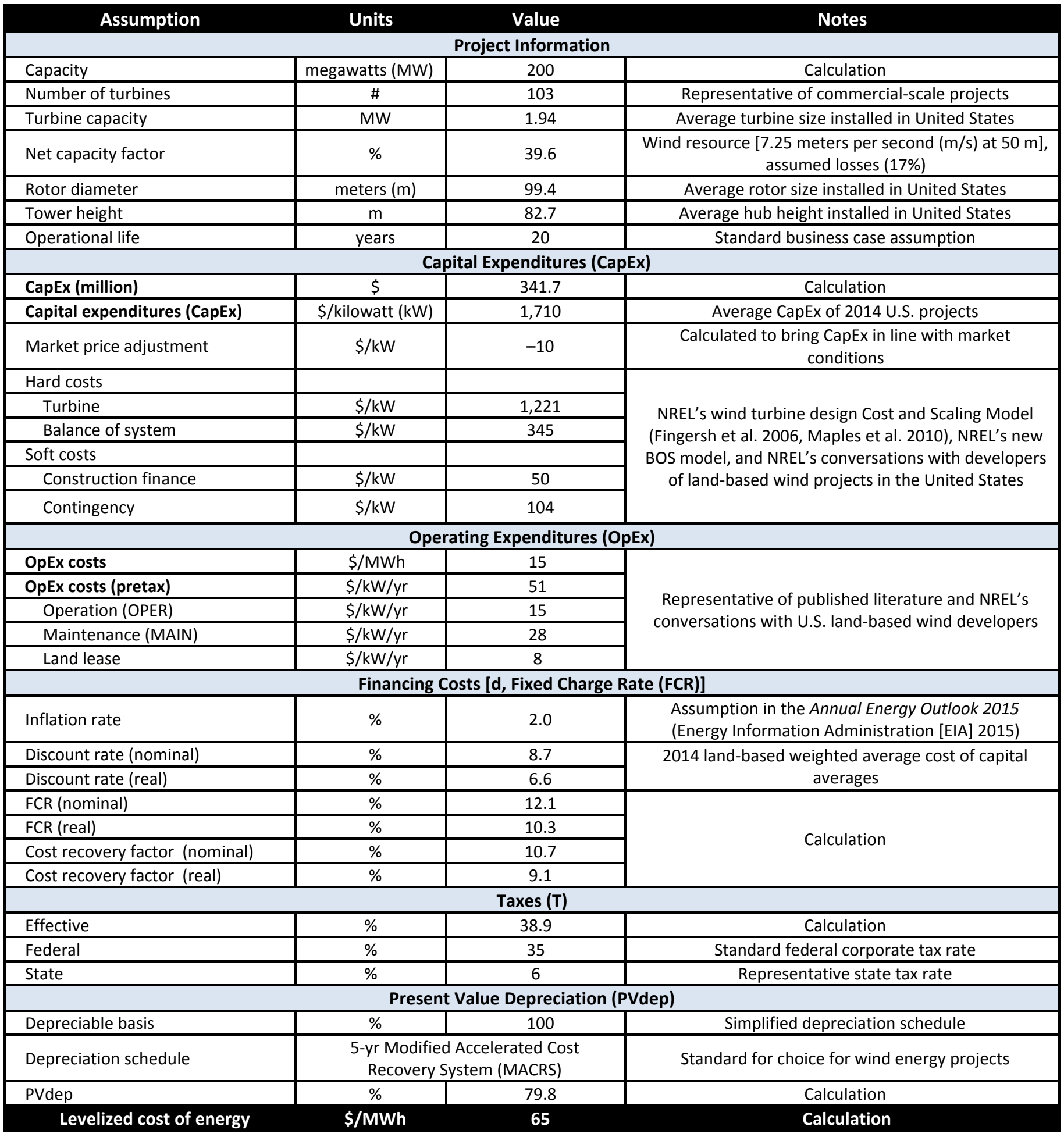




\section{Offshore Wind Project Assumptions}

Table A2. Comprehensive List of Assumptions for 2014 Offshore Reference Project COE

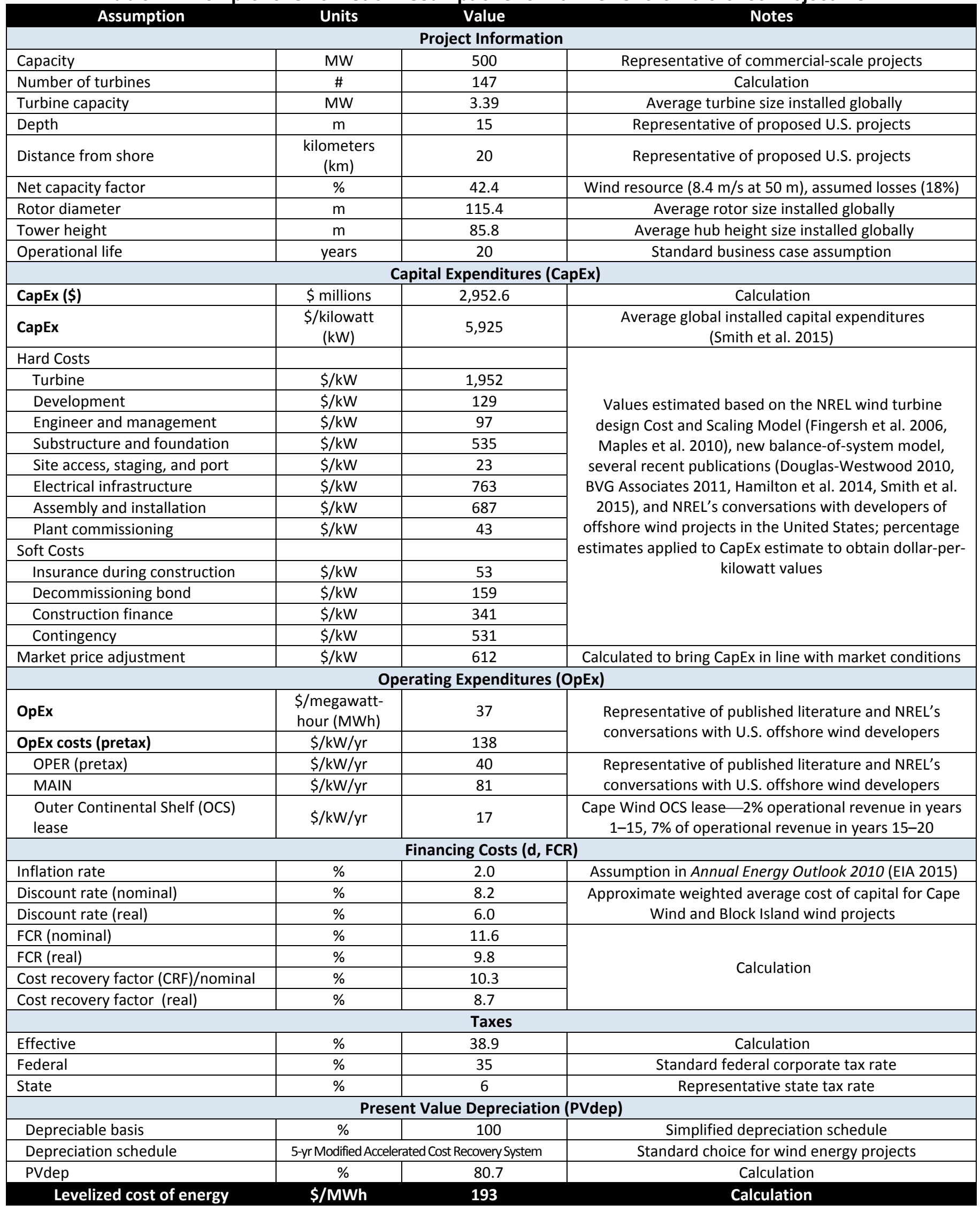




\section{Appendix B. Financial Calculations}

\section{Land-Based Wind Financial Assumptions and Calculations}

Table B1. Scenario \#1 (IEA Structure) and Present Value of Depreciation Calculations $(d=8.7 \%)$

\begin{tabular}{|l|c|c|c|}
\hline \multicolumn{1}{|c|}{ Parameters } & Percentage & $\begin{array}{c}\text { Nominal } \\
\text { Rate }\end{array}$ & Real Rate \\
\hline Tax Equity (After-Tax Yield) & $55 \%$ & $8.00 \%$ & $5.88 \%$ \\
Cash Equity (After-Tax Yield) & $45 \%$ & $9.60 \%$ & $7.40 \%$ \\
\hline Income Tax & & & \\
Federal & & $35.0 \%$ & $35.0 \%$ \\
State (6\%) & & $6.0 \%$ & $6.0 \%$ \\
Composite & $38.9 \%$ & $38.9 \%$ \\
\hline Discount Rate (after tax) & & $8.7 \%$ & $6.6 \%$ \\
Present Value Depreciation & & $\mathbf{7 9 . 7 \%}$ & $\mathbf{7 9 . 7 \%}$ \\
Fixed Charge Rate (FCR) & & $\mathbf{1 2 . 1 \%}$ & $\mathbf{1 0 . 3 \%}$ \\
\hline
\end{tabular}

\begin{tabular}{|c|c|c|c|c|c|}
\hline Year & $\begin{array}{l}\text { Net Book } \\
\text { Value }\end{array}$ & $\begin{array}{l}\text { 5-Year MACRS } \\
\text { Depreciation } \\
\text { Schedule }\end{array}$ & Depreciation & $\begin{array}{l}\text { Present Value } \\
\text { Depreciation }\end{array}$ & $\begin{array}{l}\text { Accumulated } \\
\text { Present Value } \\
\text { Depreciation }\end{array}$ \\
\hline 1 & 100 & $20.00 \%$ & 20 & 18.4 & 18.4 \\
\hline 2 & 80 & $32.00 \%$ & 32 & 27.08 & 45.48 \\
\hline 3 & 48 & $19.20 \%$ & 19.2 & 14.95 & 60.43 \\
\hline 4 & 28.8 & $11.52 \%$ & 11.52 & 8.25 & 68.68 \\
\hline 5 & 17.28 & $11.52 \%$ & 11.52 & 7.59 & 76.27 \\
\hline 6 & 5.76 & $5.76 \%$ & 5.76 & 3.49 & 79.76 \\
\hline
\end{tabular}

Table B2. Scenario \#2 (Partnership Flip Structure) and Present Value of Depreciation Calculations $(d=$ $9.4 \%)$

\begin{tabular}{|l|c|c|c|}
\hline \multicolumn{1}{|c|}{ Parameters } & Percentage & $\begin{array}{c}\text { Nominal } \\
\text { Rate }\end{array}$ & Real Rate \\
\hline Tax Equity (After-Tax Yield) & $55 \%$ & $8.00 \%$ & $5.88 \%$ \\
Cash Equity (After-Tax Yield) & $45 \%$ & $10.75 \%$ & $8.58 \%$ \\
\hline Income Tax & & & \\
Federal & & $35.0 \%$ & $35.0 \%$ \\
State (6\%) & & $6.0 \%$ & $6.0 \%$ \\
Composite & $38.9 \%$ & $38.9 \%$ \\
\hline Discount Rate (after tax) & & $9.4 \%$ & $7.2 \%$ \\
Present Value Depreciation & & $\mathbf{7 8 . 7 \%}$ & $\mathbf{7 8 . 7 \%}$ \\
Fixed Charge Rate (FCR) & & $\mathbf{1 2 . 7 \%}$ & $\mathbf{1 0 . 8 \%}$ \\
\hline
\end{tabular}

\begin{tabular}{|c|c|c|c|c|c|}
\hline Year & $\begin{array}{l}\text { Net Book } \\
\text { Value }\end{array}$ & $\begin{array}{l}\text { 5-Year MACRS } \\
\text { Depreciation } \\
\text { Schedule }\end{array}$ & Depreciation & $\begin{array}{l}\text { Present Value } \\
\text { Depreciation }\end{array}$ & $\begin{array}{l}\text { Accumulated } \\
\text { Present Value } \\
\text { Depreciation }\end{array}$ \\
\hline 1 & 100 & $20.00 \%$ & 20 & 18.31 & 18.31 \\
\hline 2 & 80 & $32.00 \%$ & 32 & 26.82 & 45.13 \\
\hline 3 & 48 & $19.20 \%$ & 19.2 & 14.73 & 59.86 \\
\hline 4 & 28.8 & $11.52 \%$ & 11.52 & 8.09 & 67.95 \\
\hline 5 & 17.28 & $11.52 \%$ & 11.52 & 7.41 & 75.36 \\
\hline 6 & 5.76 & $5.76 \%$ & 5.76 & 3.39 & 78.75 \\
\hline
\end{tabular}

\section{Table B3. Scenario \#3 (Tax/Cash Equity with Back-Leverage) and Present Value of Depreciation} Calculations $(d=8.0 \%)$

\begin{tabular}{|l|c|c|c|}
\hline \multicolumn{1}{|c|}{ Parameters } & Percentage & $\begin{array}{c}\text { Nominal } \\
\text { Rate }\end{array}$ & Real Rate \\
\hline Tax Equity (After-Tax Yield) & $55 \%$ & $8.00 \%$ & $5.88 \%$ \\
Cash Equity (After-Tax Yield) & $18 \%$ & $15.00 \%$ & $12.75 \%$ \\
HoldCo Debt (Pre-Tax Interest) & $27 \%$ & $5.50 \%$ & $3.43 \%$ \\
\hline Income Tax & & & \\
Federal & & $35.0 \%$ & $35.0 \%$ \\
State (6\%) & & $6.0 \%$ & $6.0 \%$ \\
Composite & & $38.9 \%$ & $38.9 \%$ \\
\hline Discount Rate (after tax) & & $8.6 \%$ & $6.5 \%$ \\
Present Value Depreciation & & $81.1 \%$ & $81.1 \%$ \\
Fixed Charge Rate (FCR) & & $\mathbf{1 0 . 6 \%}$ & $\mathbf{9 . 0 \%}$ \\
\hline
\end{tabular}

\begin{tabular}{|c|c|c|c|c|c|}
\hline Year & $\begin{array}{l}\text { Net Book } \\
\text { Value }\end{array}$ & $\begin{array}{l}\text { 5-Year MACRS } \\
\text { Depreciation } \\
\text { Schedule }\end{array}$ & Depreciation & $\begin{array}{l}\text { Present Value } \\
\text { Depreciation }\end{array}$ & $\begin{array}{l}\text { Accumulated } \\
\text { Present Value } \\
\text { Depreciation }\end{array}$ \\
\hline 1 & 100 & $20.00 \%$ & 20 & 18.51 & 18.51 \\
\hline 2 & 80 & $32.00 \%$ & 32 & 27.43 & 45.94 \\
\hline 3 & 48 & $19.20 \%$ & 19.2 & 15.24 & 61.18 \\
\hline 4 & 28.8 & $11.52 \%$ & 11.52 & 8.47 & 69.65 \\
\hline 5 & 17.28 & $11.52 \%$ & 11.52 & 7.84 & 77.49 \\
\hline 6 & 5.76 & $5.76 \%$ & 5.76 & 3.63 & 81.12 \\
\hline
\end{tabular}




$$
\begin{aligned}
& \text { LCOE }=\frac{\text { FCR } * \text { CAPEX }+ \text { FOM }}{\text { CF } \times 8760}+\text { VOM }+ \text { FUEL } \\
& F C R=\text { CRF } * \text { ProFinFactor } \\
& \text { CAPEX }=\text { ConFinFactor } *(\text { OCC } * \text { RegCapMult }+ \text { GCC })
\end{aligned}
$$

\begin{tabular}{|c|c|}
\hline $\begin{array}{l}\text { Fixed operation } \\
\text { and maintenance } \\
\text { (FOM) }\end{array}$ & OPER in the system cost breakdown structure (SCBS) \\
\hline $\begin{array}{l}\text { Variable } \\
\text { operation and } \\
\text { maintenance } \\
\text { (VOM) }\end{array}$ & MAIN in the SCBS \\
\hline Fuel & N/A in wind \\
\hline ProFinFactor & $\begin{array}{l}\text { Technology-specific financial multiplier to account for any applicable differences in } \\
\text { depreciation schedule }\end{array}$ \\
\hline ConFinFactor & $\begin{array}{l}\text { Portion of capital expenditure associated with construction period financing; } \\
\text { ConFinFactor is a function of construction period duration, interest rate, and } \\
\text { expenditure schedule }\end{array}$ \\
\hline $\begin{array}{l}\text { Overnight capital } \\
\text { cost (OCC) }\end{array}$ & $\begin{array}{l}\text { Capital expenditures excluding construction period financing; includes onsite } \\
\text { electrical equipment (e.g., switchyard), a nominal-distance spur line }(<1 \mathrm{mi}) \text {, and } \\
\text { necessary upgrades at a transmission substation }\end{array}$ \\
\hline CapRegMult & $\begin{array}{l}\text { Capital cost multipliers to account for regional variations that affect plant costs, } \\
\text { (e.g., labor rates); ATB does not represent these regional impacts (CapRegMult = } \\
\text { 0), but standard scenarios outputs do include regional impacts for some } \\
\text { technologies }\end{array}$ \\
\hline $\begin{array}{l}\text { Grid Connections } \\
\text { Costs (GCC) }\end{array}$ & $\begin{array}{l}\text { Spur line costs from the plant gate to the high-voltage transmission network based } \\
\text { on geographic distance; ATB does not represent distance-based grid connections } \\
\text { costs (GCC=0), with the exception of offshore wind plants. Standard scenarios } \\
\text { outputs do include site-specific grid connection costs for wind }\end{array}$ \\
\hline
\end{tabular}

Table B4. Summary of Annual Technology Baseline-Specific Terms Used in the Supply Curve Analysis 
Table B5. Summary of ATB-Specific Financial and Present Value Depreciation Calculations $(d=\mathbf{8 . 9} \%)$

\begin{tabular}{|lc|}
\multicolumn{2}{|c|}{ Financial Assumptions: } \\
\hline \\
\hline Inflation Rate \\
\hline Economic Lifetime (Years) & $2.5 \%$ \\
\hline Interest Rate - Nominal & 20 \\
\hline Calculated Interest Rate - Real & $8.0 \%$ \\
\hline Interest During Construction - Nominal & $5.4 \%$ \\
\hline Rate of Return on Equity - Nominal & $8.0 \%$ \\
\hline Calculated Rate of Return on Equity - Real & $13.0 \%$ \\
\hline Debt Fraction & $12.5 \%$ \\
\hline Tax Rate (Federal and State) & $50.0 \%$ \\
\hline WACC - Nominal & $40.0 \%$ \\
\hline WACC - Real & $8.9 \%$ \\
\hline Depreciation Period & $6.2 \%$ \\
\hline Construction Finance Factor & 5 \\
\hline Present Value of Depreciation & 1.039 \\
\hline Project Finance Factor & 0.794 \\
\hline Capital Recovery Factor (CRF) - Nominal & 1.134 \\
\hline Capital Recovery Factor (CRF) - Real & $10.9 \%$ \\
\hline
\end{tabular}

\begin{tabular}{|c|c|c|c|c|c|}
\hline Year & $\begin{array}{l}\text { Net Book } \\
\text { Value }\end{array}$ & $\begin{array}{c}\text { 5-Year MACRS } \\
\text { Depreciation } \\
\text { Schedule }\end{array}$ & Depreciation & $\begin{array}{l}\text { Present Value } \\
\text { Depreciation }\end{array}$ & $\begin{array}{l}\text { Accumulated } \\
\text { Present } \\
\text { Value } \\
\text { Depreciation }\end{array}$ \\
\hline 1 & 100 & $20.00 \%$ & 20 & 18.37 & 18.37 \\
\hline 2 & 80 & $32.00 \%$ & 32 & 26.98 & 45.35 \\
\hline 3 & 48 & $19.20 \%$ & 19.2 & 14.87 & 60.22 \\
\hline 4 & 28.8 & $11.52 \%$ & 11.52 & 8.19 & 68.41 \\
\hline 5 & 17.28 & $11.52 \%$ & 11.52 & 7.52 & 75.93 \\
\hline 6 & 5.76 & $5.76 \%$ & 5.76 & 3.45 & 79.38 \\
\hline
\end{tabular}

MACRS: Modified Accelerated Cost Recovery System

\section{Offshore Wind Financial Assumptions and Calculations}

Table B6. Scenario \#1 (Equity with Back-Leverage) and Present Value of Depreciation Calculations $(d=8.1 \%)$

\begin{tabular}{|l|c|c|c|}
\hline \multicolumn{1}{|c|}{ Parameters } & Percentage & $\begin{array}{c}\text { Nominal } \\
\text { Rate }\end{array}$ & Real Rate \\
\hline Tax Equity (After-Tax Yield) & $55 \%$ & $8.00 \%$ & $5.88 \%$ \\
Sponsor Equity (After-Tax Yield) & $18 \%$ & $15.00 \%$ & $12.75 \%$ \\
Sponsor Debt (Pre-Tax Interest) & $27 \%$ & $6.00 \%$ & $3.92 \%$ \\
\hline Income Tax & & & \\
Federal & & $35.0 \%$ & $35.0 \%$ \\
\hline State (6\%) & & $6.0 \%$ & $6.0 \%$ \\
Composite & & $38.9 \%$ & $38.9 \%$ \\
\hline Discount Rate (after tax) & & $8.1 \%$ & $6.0 \%$ \\
Present Value Depreciation & & $\mathbf{1 1 . 5 \%}$ & $\mathbf{8 0 . 9 5 \%}$ \\
\hline Fixed Charge Rate (FCR) & & $\mathbf{9 . 8 \%}$ \\
\hline
\end{tabular}

\begin{tabular}{|c|c|c|c|c|c|}
\hline Year & $\begin{array}{c}\text { Net Book } \\
\text { Value }\end{array}$ & $\begin{array}{c}5-Y e a r \text { MACRS } \\
\text { Depreciation } \\
\text { Schedule }\end{array}$ & Depreciation & $\begin{array}{c}\text { Present Value } \\
\text { Depreciation }\end{array}$ & $\begin{array}{c}\text { Accumulated } \\
\text { Present Value } \\
\text { Depreciation }\end{array}$ \\
\hline $\mathbf{1}$ & 100 & $20.00 \%$ & 20 & 18.5 & 18.5 \\
\hline $\mathbf{2}$ & 80 & $32.00 \%$ & 32 & 27.39 & 45.89 \\
\hline $\mathbf{3}$ & 48 & $19.20 \%$ & 19.2 & 15.2 & 61.09 \\
\hline $\mathbf{4}$ & 28.8 & $11.52 \%$ & 11.52 & 8.44 & 69.53 \\
\hline $\mathbf{5}$ & 17.28 & $11.52 \%$ & 11.52 & 7.81 & 77.34 \\
\hline $\mathbf{6}$ & 5.76 & $5.76 \%$ & 5.76 & 3.61 & 80.95 \\
\hline
\end{tabular}

MACRS: Modified Accelerated Cost Recovery System

Table B7. Scenario \#2 (Nonrecourse Project Finance) and Present Value of Depreciation Calculations $(d=9.7 \%)$

\begin{tabular}{|l|c|c|c|}
\hline \multicolumn{1}{|c|}{ Parameters } & Percentage & $\begin{array}{c}\text { Nominal } \\
\text { Rate }\end{array}$ & Real Rate \\
\hline Tax Equity (After-Tax Yield) & $40 \%$ & $15.00 \%$ & $12.75 \%$ \\
Cash Equity (After-Tax Yield) & $60 \%$ & $10.00 \%$ & $7.84 \%$ \\
\hline Income Tax & & & \\
Federal & & $35.0 \%$ & $35.0 \%$ \\
State (6\%) & & $6.0 \%$ & $6.0 \%$ \\
Composite & $38.9 \%$ & $38.9 \%$ \\
\hline Discount Rate (after tax) & & $9.7 \%$ & $7.5 \%$ \\
Present Value Depreciation & & $\mathbf{7 7 . 9 \%}$ & $77.9 \%$ \\
Fixed Charge Rate (FCR) & & $\mathbf{1 3 . 1 \%}$ & $\mathbf{1 1 . 2 \%}$ \\
\hline
\end{tabular}

\begin{tabular}{|c|c|c|c|c|c|}
\hline Year & $\begin{array}{l}\text { Net Book } \\
\text { Value }\end{array}$ & $\begin{array}{l}\text { 5-Year MACRS } \\
\text { Depreciation } \\
\text { Schedule }\end{array}$ & Depreciation & $\begin{array}{l}\text { Present Value } \\
\text { Depreciation }\end{array}$ & $\begin{array}{l}\text { Accumulated } \\
\text { Present Value } \\
\text { Depreciation }\end{array}$ \\
\hline 1 & 100 & $20.00 \%$ & 20 & 18.24 & 18.24 \\
\hline 2 & 80 & $32.00 \%$ & 32 & 26.61 & 44.85 \\
\hline 3 & 48 & $19.20 \%$ & 19.2 & 14.56 & 59.41 \\
\hline 4 & 28.8 & $11.52 \%$ & 11.52 & 7.96 & 67.37 \\
\hline 5 & 17.28 & $11.52 \%$ & 11.52 & 7.26 & 74.63 \\
\hline 6 & 5.76 & $5.76 \%$ & 5.76 & 3.31 & 77.94 \\
\hline
\end{tabular}


Table B8. Scenario \#3 (Balance Sheet Finance) and Present Value of Depreciation Calculations $(d=7.2 \%)$

\begin{tabular}{|l|c|c|c|}
\hline \multicolumn{1}{|c|}{ Parameters } & Percentage & $\begin{array}{c}\text { Nominal } \\
\text { Rate }\end{array}$ & Real Rate \\
\hline Sponsor Equity & $30 \%$ & $8.90 \%$ & $6.76 \%$ \\
Institutional Investors & $70 \%$ & $6.50 \%$ & $4.41 \%$ \\
\hline Income Tax & & & \\
Federal & & $35.0 \%$ & $35.0 \%$ \\
State (6\%) & & $6.0 \%$ & $6.0 \%$ \\
Composite & & $38.9 \%$ & $38.9 \%$ \\
\hline Discount Rate (after tax) & & $\mathbf{7 . 2 \%}$ & $5.1 \%$ \\
Present Value Depreciation & & $\mathbf{8 2 . 7 \%}$ & $82.7 \%$ \\
Fixed Charge Rate (FCR) & & $\mathbf{1 0 . 7 \%}$ & $\mathbf{9 . 0 \%}$ \\
\hline
\end{tabular}

\begin{tabular}{|c|c|c|c|c|c|}
\hline Year & $\begin{array}{l}\text { Net Book } \\
\text { Value }\end{array}$ & $\begin{array}{l}\text { 5-Year MACRS } \\
\text { Depreciation } \\
\text { Schedule }\end{array}$ & Depreciation & $\begin{array}{l}\text { Present Value } \\
\text { Depreciation }\end{array}$ & $\begin{array}{l}\text { Accumulated } \\
\text { Present Value } \\
\text { Depreciation }\end{array}$ \\
\hline 1 & 100 & $20.00 \%$ & 20 & 18.65 & 18.65 \\
\hline 2 & 80 & $32.00 \%$ & 32 & 27.84 & 46.49 \\
\hline 3 & 48 & $19.20 \%$ & 19.2 & 15.58 & 62.07 \\
\hline 4 & 28.8 & $11.52 \%$ & 11.52 & 8.72 & 70.79 \\
\hline 5 & 17.28 & $11.52 \%$ & 11.52 & 8.13 & 78.92 \\
\hline 6 & 5.76 & $5.76 \%$ & 5.76 & 3.79 & 82.71 \\
\hline
\end{tabular}




\section{Appendix C. Summary of Historical Levelized Cost of Energy Using Reference Projects}

Table C1. Historical Land-Based Wind Plant LCOE as Calculated by NREL

\begin{tabular}{|l|c|c|c|c|c|}
\hline Parameters & 2010 COE & 2011 COE & 2012 COE & 2013 COE & 2014 COE \\
\hline Nameplate capacity (MW) & 1.5 & 1.5 & 1.94 & 1.91 & 1.94 \\
Rotor diameter (m) & 82.5 & 82.5 & 93.5 & 96.9 & 99.4 \\
Hub height (m) & 80 & 80 & 80 & 82.7 & 82.7 \\
Modeled net capacity factor (\%) & 38.0 & 37.0 & 37.5 & 38.5 & 39.6 \\
\hline Capital expenditures (\$/kW) & 2,155 & 2,098 & 1,940 & 1,728 & 1,710 \\
Fixed charge rate (\%) & 9.5 & 9.5 & 9.5 & 10.2 & 10.3 \\
Operational expenditures (\$/kW) & 55 & 55 & 55 & 50 & 51 \\
$\begin{array}{l}\text { Annual energy production } \\
\text { (MWh/MW/yr) }\end{array}$ & 3,345 & 3,263 & 3,284 & 3,410 & 3,466 \\
\hline Levelized cost of energy (\$/MWh) & $\mathbf{7 8}$ & $\mathbf{7 8}$ & $\mathbf{7 3}$ & $\mathbf{6 6}$ & $\mathbf{6 5}$ \\
\hline
\end{tabular}

Table C2. Historical Land-Based Average Wind Plant Turbine Specifications

\begin{tabular}{|l|c|c|c|c|c|}
\hline $\begin{array}{l}\text { Respective Market Turbine Parameter } \\
\text { Averages }\end{array}$ & 2010 & 2011 & 2012 & 2013 & 2014 \\
\hline Nameplate capacity (MW) & 1.79 & 1.97 & 1.94 & 1.91 & 1.94 \\
Rotor diameter (m) & 79.8 & 89 & 93.5 & 96.9 & 99.4 \\
Hub height (m) & 84.3 & 81 & 83.8 & 82.7 & 82.7 \\
\hline
\end{tabular}

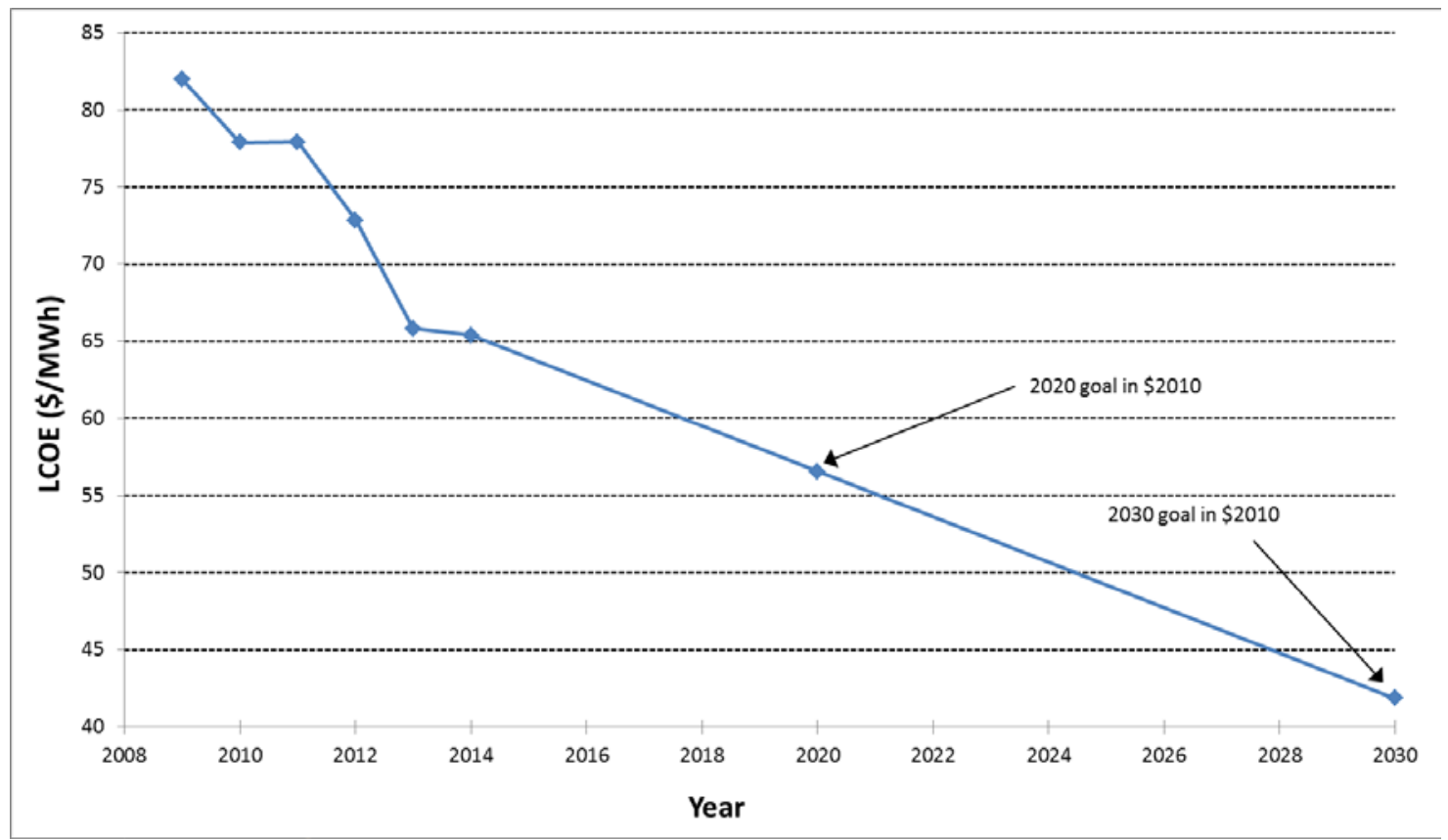

Figure C1. Historical land-based wind plant LCOE as calculated by NREL, including the U.S. Department of Energy's (DOE's) LCOE goals 
Table C3. Historical Offshore Wind Plant LCOE as Calculated by NREL

\begin{tabular}{|l|c|c|c|c|c|}
\hline Parameters & 2010 COE & 2011 COE & 2012 COE & 2013 COE & 2014 COE \\
\hline Nameplate capacity (megawatts [MW]) & 3.6 & 3.6 & 3.6 & 4.3 & 3.39 \\
Rotor diameter (m) & 107 & 107 & 107 & 119.4 & 115.4 \\
Hub height $(\mathrm{m})$ & 90 & 90 & 90 & 89.5 & 85.8 \\
Modeled net capacity factor (\%) & 39.0 & 39.0 & 39.0 & 39.0 & 42.4 \\
\hline CapEx (\$/kW) & 5,600 & 5,600 & 5,384 & 5,187 & 5,925 \\
Fixed charge rate (\%) & 11.7 & 11.7 & 11.7 & 11.7 & 9.8 \\
OpEx (\$/kW) & 136 & 136 & 136 & 136 & 138 \\
Annual energy production (MWh/MW/yr) & 3,406 & 3,406 & 3,406 & 3,463 & 3,716 \\
\hline Levelized cost of energy (\$/MWh) & $\mathbf{2 3 2}$ & $\mathbf{2 3 2}$ & $\mathbf{2 2 5}$ & $\mathbf{2 1 5}$ & $\mathbf{1 9 3}$ \\
\hline
\end{tabular}

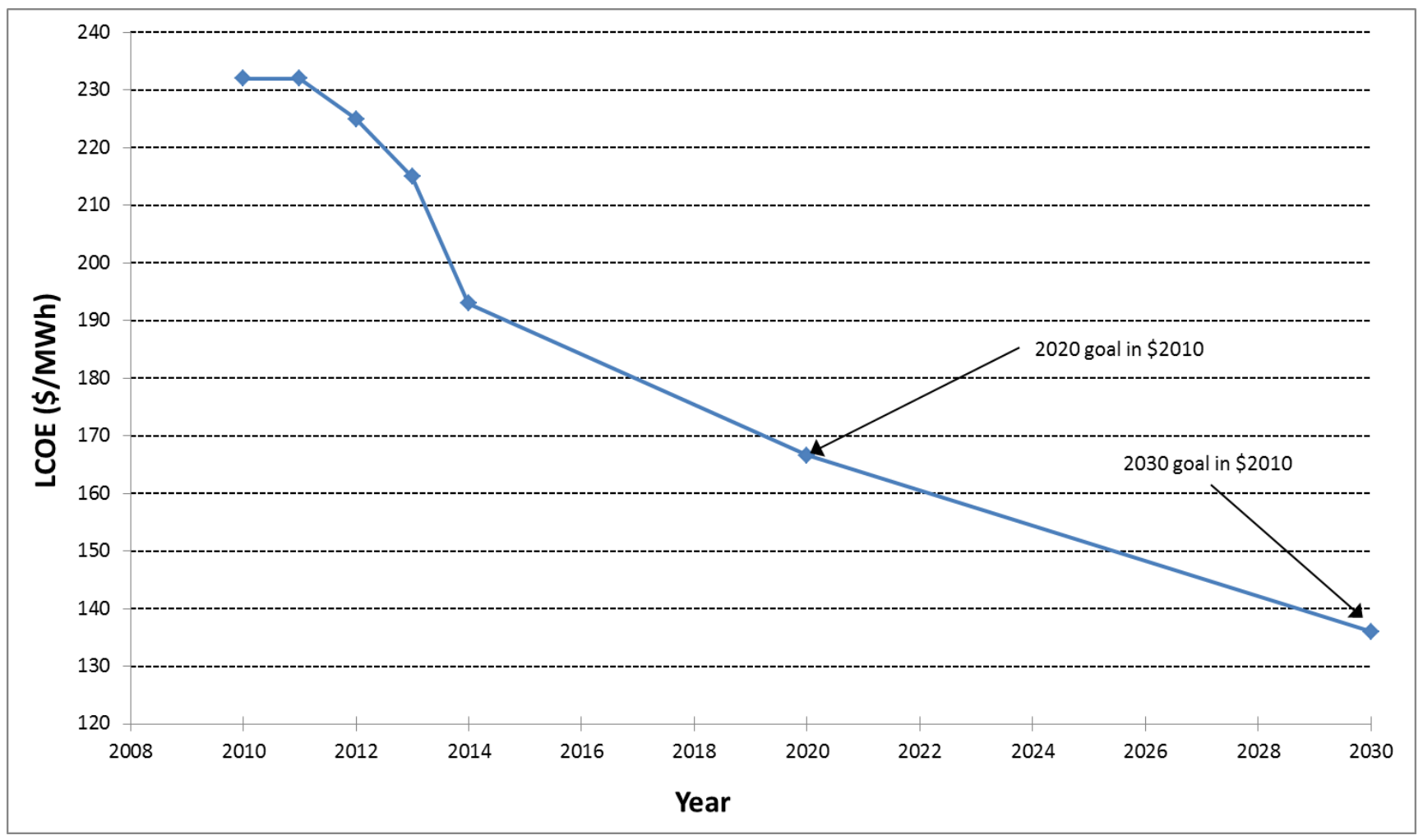

Figure C2. Historical offshore wind plant LCOE as calculated by NREL, including DOE's LCOE goals

Table C4. DOE's Cost Goals for Land-Based and Offshore Wind Power

\begin{tabular}{|l|c|c|}
\hline DOE Goals - \$2010 & 2020 & 2030 \\
\hline Land-Based LCOE $(\$ / M W h)$ & 57 & 42 \\
Offshore LCOE $(\$ / M W h)$ & 167 & 136 \\
\hline
\end{tabular}

